\title{
Recent Progress in the Abatement of Hazardous Pollutants Using Photocatalytic $\mathrm{TiO}_{2}$-Based Building Materials
}

\author{
Anantha-Iyengar Gopalan ${ }^{1,+}{ }^{\oplus}$, Jun-Cheol Lee ${ }^{2,+}$, Gopalan Saianand ${ }^{3}{ }^{\circledR}$, Kwang-Pill Lee ${ }^{1}$, \\ Prashant Sonar 4,5, Rajarathnam Dharmarajan ${ }^{3}$, Yao-long Hou ${ }^{6}$ (D), Ki-Yong Ann ${ }^{7}$, \\ Venkatramanan Kannan ${ }^{8}(\mathbb{D})$ and Wha-Jung Kim ${ }^{1, *}$ \\ 1 Daegyeong Regional Infrastructure Technology Development Center, Kyungpook National University, \\ Daegu 41566, Korea; algopal99@gmail.com (A.-I.G.); kplee@knu.ac.kr (K.-P.L.) \\ 2 Department of Architecture, Seowon University, Cheongju 28674, Korea; uggenius@hanmail.net \\ 3 Global Centre for Environmental Remediation (GCER), Faculty of Science, The University of Newcastle, \\ Callaghan, New South Wales 2308, Australia; SaiAnand.Gopalan@newcastle.edu.au (G.S.); \\ Raja.Dharmarajan@newcastle.edu.au (R.D.) \\ 4 School of Chemistry and Physics, Queensland University of Technology, 2 George Street, \\ Brisbane, QLD 4001, Australia; Sonar.Prashant@qut.edu.au \\ 5 Centre for Material Science, Queensland University of Technology, 2 George Street, \\ Brisbane, QLD 4001, Australia \\ 6 Department of Civil Engineering, Kyungpook National University, 80 Daehakro, Buk-gu, \\ Daegu 41566, Korea; hylmm8988@hotmail.com \\ 7 Department of Civil and Environmental Engineering, Hanyang University, Ansan 1588, Korea; \\ kann@hanyang.ac.kr \\ 8 Department of Physics, SCSVMV Deemed University, Kanchipuram 631561, India; kv@kanchiuniv.ac.in \\ * Correspondence: kimwj@knu.ac.kr; Tel.: +82-53-950-6335 \\ + These authors contributed equally to this work.
}

Received: 7 August 2020; Accepted: 11 September 2020; Published: 16 September 2020

Abstract: Titanium dioxide $\left(\mathrm{TiO}_{2}\right)$ has been extensively investigated in interdisciplinary research (such as catalysis, energy, environment, health, etc.) owing to its attractive physico-chemical properties, abundant nature, chemical/environmental stability, low-cost manufacturing, low toxicity, etc. Over time, $\mathrm{TiO}_{2}$-incorporated building/construction materials have been utilized for mitigating potential problems related to the environment and human health issues. However, there are challenges with regards to photocatalytic efficiency improvements, lab to industrial scaling up, and commercial product production. Several innovative approaches/strategies have been evolved towards $\mathrm{TiO}_{2}$ modification with the focus of improving its photocatalytic efficiency. Taking these aspects into consideration, research has focused on the utilization of many of these advanced $\mathrm{TiO}_{2}$ materials towards the development of construction materials such as concrete, mortar, pavements, paints, etc. This topical review focuses explicitly on capturing and highlighting research advancements in the last five years (mainly) (2014-2019) on the utilization of various modified $\mathrm{TiO}_{2}$ materials for the development of practical photocatalytic building materials (PBM). We briefly summarize the prospective applications of $\mathrm{TiO}_{2}$-based building materials (cement, mortar, concretes, paints, coating, etc.) with relevance to the removal of outdoor/indoor $\mathrm{NO}_{\mathrm{x}}$ and volatile organic compounds, self-cleaning of the surfaces, etc. As a concluding remark, we outline the challenges and make recommendations for the future outlook of further investigations and developments in this prosperous area.

Keywords: building materials; photocatalytic; titanium dioxide; pollutant removal; self-cleaning 


\section{Introduction}

In recent years, challenges regarding air pollution based on particulate matter (PM) and toxic gases that are arising from anthropogenic or external sources have become severe issues [1]. Research activities are being directed to resolve air pollution-related matters through the process of making practical remedial measures. Air pollution can occur both in indoor (e.g., household) contexts and in outdoor environments. Common hazardous compounds include $\mathrm{NO}_{\mathrm{x}}, \mathrm{SO}_{\mathrm{x}}, \mathrm{CO}, \mathrm{H}_{2} \mathrm{~S}, \mathrm{NH}_{3}$, other nitrogen compounds (e.g., hydrogen cyanide), sulfur-containing compounds (organothiols), hydrocarbons, and a myriad of volatile organic compounds (VOCs) (benzene, toluene, methanol, etc.) which are of significant concern for environmental remediation [2]. The primary sources of these gaseous pollutants are anthropogenic. Mainly, VOCs based on alkanes, aromatics, esters, alkenes, carboxylic acids, and alcohols can exist in indoor environments, especially inside building spaces, originating from adhesives, carpeting, wood products, or cleaning products [3]. These indoor air pollutants can cause health issues, such as breathing problems, for people with compromised or underdeveloped immune systems [4,5]. On the other hand, fossil fuel burning by motor vehicles (including cars, buses, trucks, etc.) and power plants (including coal-fired and natural gas plants) can expel a mixture of pollutants, such as tiny particles or PM, NO also originate indirectly from the air when primary pollutants react or interact with each other or with other environmentally existing gaseous molecules. For example, chemical interactions between $\mathrm{SO}_{\mathrm{x}}$ and $\mathrm{NO}_{\mathrm{x}}$ can produce ground level ozone, and this can happen in the upper atmosphere too, leading to photochemical smog and acid rain [10]. These outdoor and secondary pollutants can cause environmental and human health issues.

Gaseous pollutants are mainly controlled or removed by a few significant techniques: absorption, adsorption, chemical oxidation, and incineration. These techniques may be employed either singly or in combination, which, in turn, can be decided based on the type of pollutant. Gas adsorption is a surface phenomenon where gas molecules are adsorbed or are attracted to the surface and held on the surface of the solid. These approaches for the depollution process, however, are constrained with drawbacks [11]. For example, while activated carbon [12,13] adsorption can lead to secondary pollution, incineration and catalytic oxidation are expensive and consume more energy. Photocatalysis is a rapidly evolving technology for the treatment of air pollutants and is considered as one of the most effective methods to remediate environmental gaseous pollutants. Photocatalysis refers to the conversion of photon energy into chemical energy and the acceleration of photoreactions in the presence of a photocatalyst. Photocatalysis offers several advantages over the conventional catalytic processes that involve time-consuming steps, elevated temperatures, and pressures. Typically, photocatalysis, or photocatalytic oxidation (PCO), has been effectively employed for the removal of low concentrations [i.e., part per billion ( $\mathrm{ppb}$ ) level] of gaseous pollutants, with distinct advantages that include ambient temperature operations, minimum energy consumption, and effectiveness for various contaminants with innocuous final products [14].

Several metal-oxide based semiconductors, such as titanium dioxide $\left(\mathrm{TiO}_{2}\right)$ [15-18], zinc oxide ( $\mathrm{ZnO})$ [19-27], copper oxide $(\mathrm{CuO})$ [28-31], zirconium oxide or zirconia $\left(\mathrm{ZrO}_{2}\right)$, cerium oxide $\left(\mathrm{CeO}_{2}\right)$ [29], tungsten oxide $\left(\mathrm{WO}_{3}\right)$, and tin oxide $\left(\mathrm{SnO}_{2}\right)$, have been successfully demonstrated as efficient photocatalysts for pollutant removal [32-34] and utilized in several other applications (energy, environment, and health) [35-37]. The semiconductor photocatalytic process includes irradiation of the semiconductor surface with a light having energy greater than the semiconductor's bandgap. This triggers the excitation of valence band (VB) electrons and transfers to the conduction band (CB) to create electron-hole pair $\left(\mathrm{e}^{-}-\mathrm{h}^{+}\right)$. These charge carriers subsequently participate in reactions between the pollutant molecules and radicals generated on the surface of the semiconductor [38,39]. The rapid development and convergence of the critical scientific components, such as catalysis science, nanoscience, and material characterizations, form the basis for significant advances in the development of new photocatalysts, photocatalytic reaction mechanisms, and the structure-photo activity relationship between photocatalysts and target pollutants [40-44]. More interestingly, the structural features of 
photocatalysts can be further fine-tuned to derive enhanced photocatalytic performances for the depollution process [42]. Particularly, semiconductor photocatalysts have been proved to exhibit significant efficiency for the degradation of both organic and inorganic pollutants.

$\mathrm{TiO}_{2}$ is one of the popular commercial photocatalysts which is prevalently used for the photo-degradation of many pollutants. $\mathrm{TiO}_{2}$ offers major advantageous characteristics, such as ease of synthesis and versatility of application. $\mathrm{TiO}_{2}$-based photocatalysis has proven to be a very promising advanced oxidation process for the depollution and cleaning of indoor and outdoor air, exhibiting unique advantages over conventional remediation technologies. Through a significant number of research studies, the unique photocatalytic properties of $\mathrm{TiO}_{2}$ structures, or the phase compositions that facilitate the oxidation of nitrogen oxide (NO) to nitrogen dioxide $\left(\mathrm{NO}_{2}\right)$ and then to nitric acid $\left(\mathrm{HNO}_{3}\right)$, as well as the conversion of $\mathrm{VOCs}$ to $\mathrm{CO}_{2}$ and $\mathrm{H}_{2} \mathrm{O}$ under ultraviolet (UV) irradiation, have been well documented. Continuous research activities are being directed towards improving the photocatalytic efficiency of $\mathrm{TiO}_{2}$ via preparation of nanostructured $\mathrm{TiO}_{2}$, doping with non-metal (C, N, S, and I) and metal ions ( $\mathrm{Cr}, \mathrm{Mn}, \mathrm{Fe}$, and Ni), preparation of different polymorphs and their mixtures, composite formation, etc. (Scheme 1). The commonly known anatase and rutile forms of $\mathrm{TiO}_{2}$ belong to the large bandgap semiconductors with bandgap energies of 3.2 and $3.0 \mathrm{eV}$, respectively [45]. However, chemical/structural modifications of $\mathrm{TiO}_{2}$ can result in the decrease in the bandgap in such a way that $\mathrm{TiO}_{2}$ could be effectively used for the transformation/degradation of environmental pollutants/contaminants under solar or visible light irradiation.

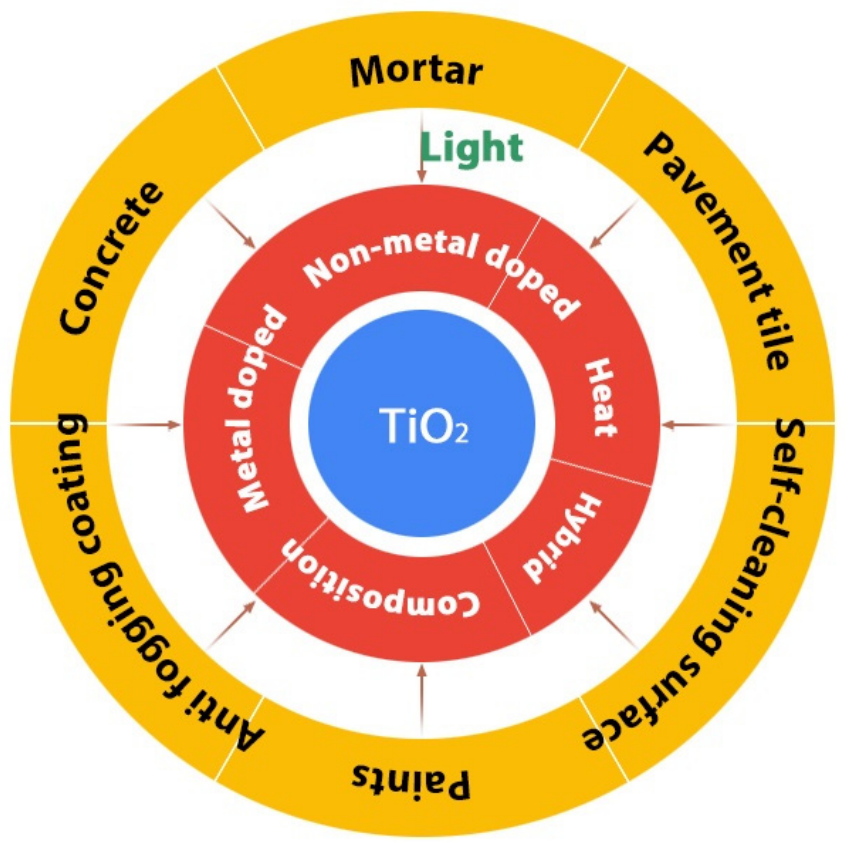

Scheme 1. General schematic showing the prospects of titanium dioxide $\left(\mathrm{TiO}_{2}\right)$ in buildingrelated applications.

It is being projected that there will be a three-fold increase in the numbers of commercial and institutional buildings in 2050 as compared to 2010. Globally, buildings account for nearly $20 \%$ to $40 \%$ of energy consumption in developed countries, even surpassing the possible contributions from the industrial and transportation sectors [46]. As a result, it is believed that the flow of the economy is expected to be largely based on the construction industry. With regards to buildings, construction materials are used in a significant part of their construction, and they are directly exposed to people. It is expected, therefore, that the indoor environment is strongly influenced by the nature of building material and, additionally, by the quality and cost of the construction $[47,48]$. Extensive academic research activities on various aspects of $\mathrm{TiO}_{2}$ significantly provide the basis for the utility of $\mathrm{TiO}_{2}$ in 
practical applications, especially as a photocatalytic construction/building material. The advantages of using $\mathrm{TiO}_{2}$ as a photocatalytic building material over the other semiconductor photocatalysts are: (a) less expensive and higher chemical stability and safety; (b) high photocatalytic activity; (c) compatibility with traditional construction materials; (d) effectiveness under solar light irradiation in ambient/atmospheric environments. Based on some laboratory and feasibility studies towards its practical applications $[49,50]$, it has been demonstrated that $\mathrm{TiO}_{2}$-based photocatalytically active construction materials can be useful for gaseous depollution and environmental cleaning processes [51]. Also, practical condition test results on the air purification effect of $\mathrm{TiO}_{2}$ included cementitious materials that have been reported [52].

In recent years (especially the last five years, 2014-2019), several innovative approaches have been developed towards $\mathrm{TiO}_{2}$ modifications, focusing on the improvement of its photocatalytic efficiency. Notably, research has focused on the utilization of many of these advanced $\mathrm{TiO}_{2}$ materials and their derived photocatalytic activities for the development of construction materials, such as concrete, mortar, pavements, paints, etc. (Scheme 1). For example, the combination of photocatalytic oxidation activity and photo-induced super-hydrophilicity was utilized to develop $\mathrm{TiO}_{2}$-based building materials, such as tiles, coated glasses, paint films, and tent material, having a self-cleaning property with excellent durability. Detailed information has been well demonstrated by researchers based on the results achieved with generalized use of self-cleaning surfaces, which are intended to provide buildings with a long-time stable aesthetic appearance. In parallel, the capability of photocatalysis in cementitious materials has been established in laboratories, at pilot scales, and, more recently, with some specific in-field monitoring programs towards the reduction of the levels of urban pollution and related developments. The additional benefits of improving indoor air quality can be exploited by utilizing photocatalysis involving $\mathrm{TiO}_{2}$-inclusive building materials. For example, coating a layer of cement endowed with photocatalytic properties on building walls in conjunction with exposure to appropriate light sources has been demonstrated to decrease pollution levels in confined (indoor) environments. Therefore, indoor or outdoor environments containing low pollutant concentrations (at ppb levels) can be effectively controlled to have minimized pollution levels through the use of photocatalytically active building materials; this forms the basis for a promising field of application. It must be noted that traditional air purification technologies are less efficient and economically less competitive for the treatment of low concentrations of pollutants present in indoor air streams. It is noteworthy that the photocatalytic coating approach is not only useful to retain the aesthetic characteristics of concrete structures based on white cement but also reduces the discoloration effect of the wall surface because of the accumulation of organic pollutants. Even so, adequately designed $\mathrm{TiO}_{2}$-cement composites can retain the aesthetic characteristics of building walls over longer durations, even in an aggressive outdoor environment. The significant applications of $\mathrm{TiO}_{2}$-based photocatalytic building materials can be grouped under environmental pollution remediation, self-cleaning, and self-disinfecting. However, the inclusion of a $\mathrm{TiO}_{2}$ photocatalyst into construction materials, such as cement-based products, or its immobilization onto the external surfaces of other materials, such as construction tiles, has become an appealing challenge for exploiting the unique properties of the PCO process and establishing its practical application for the removal of air pollutants in urban areas.

On perusal of the published scientific literature through "Web of Science", using the keyword "building materials" over the years 2010 to 2019 , the database indicated the appearance of $\sim 85,140$ records (mainly in the form of articles, reviews, and proceedings). Typically, the number of research articles and reviews nearly doubled in the years 2015-2019 as compared to the years 2010-2014 (Scheme 2a). On further refining, for a search with the keyword "photocatalytic", one could notice that the number of published research articles significantly increased (about 2.5 times) for the years 2014-2019, as compared to the research articles in the years 2010-2014 (Scheme 2a). To note, the number of reviews published on the topic "photocatalytic building materials" also showed such an increasing trend ( 21 (2010-2014) vs. 67 (2015-2019) (Scheme 2b). Notably, $\mathrm{TiO}_{2}$ (especially the commercial material Degussa-Evonik P25) was predominantly used for the "PBM based applications" against other photoactive materials, 
indicating the predominance of $\mathrm{TiO}_{2}$ over the other photoactive materials. While research activities on " $\mathrm{TiO}_{2}$ based building materials" showed a sluggish improvement between the years 2010-2014, a sharp increase in research activities was observed in the years 2015-2019 (Scheme 2b). Also, in recent years, researchers started focusing their interest on developing "smart building materials" using $\mathrm{TiO}_{2}$.

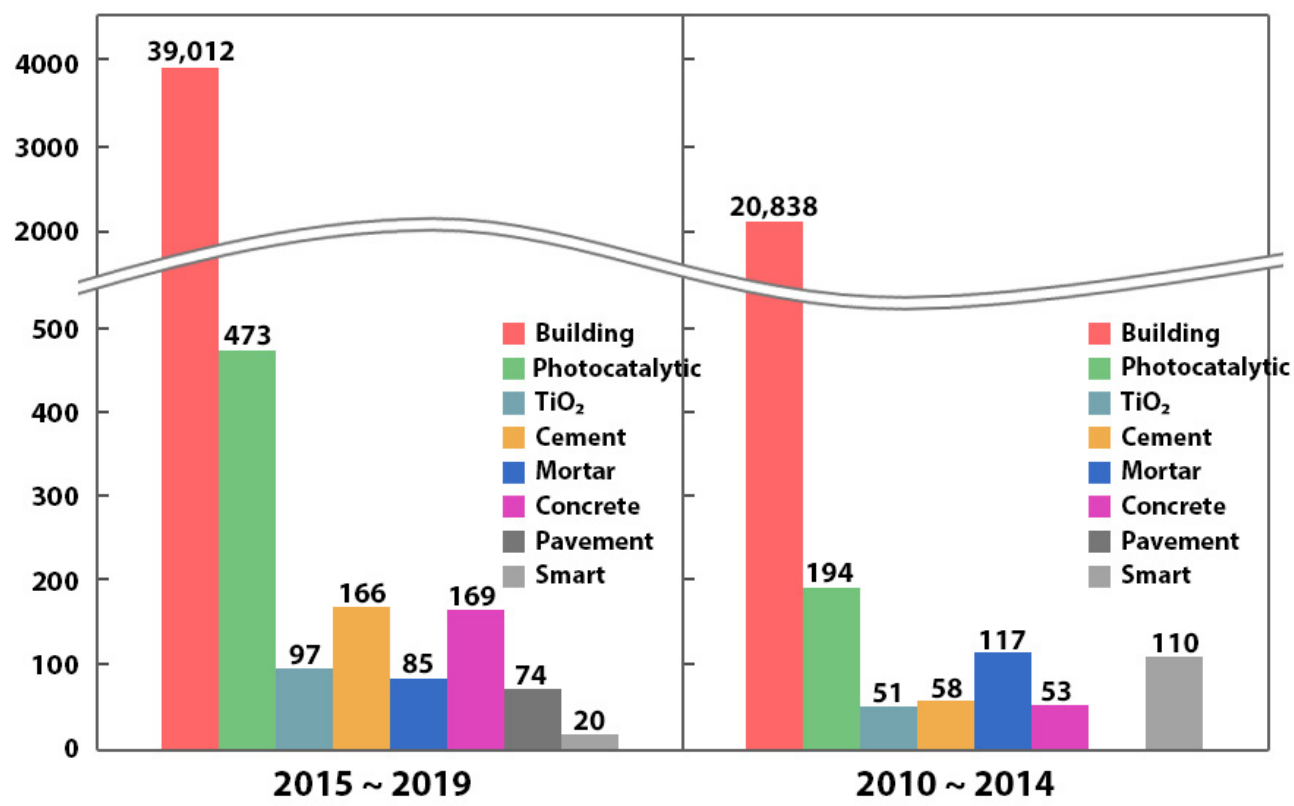

(a)

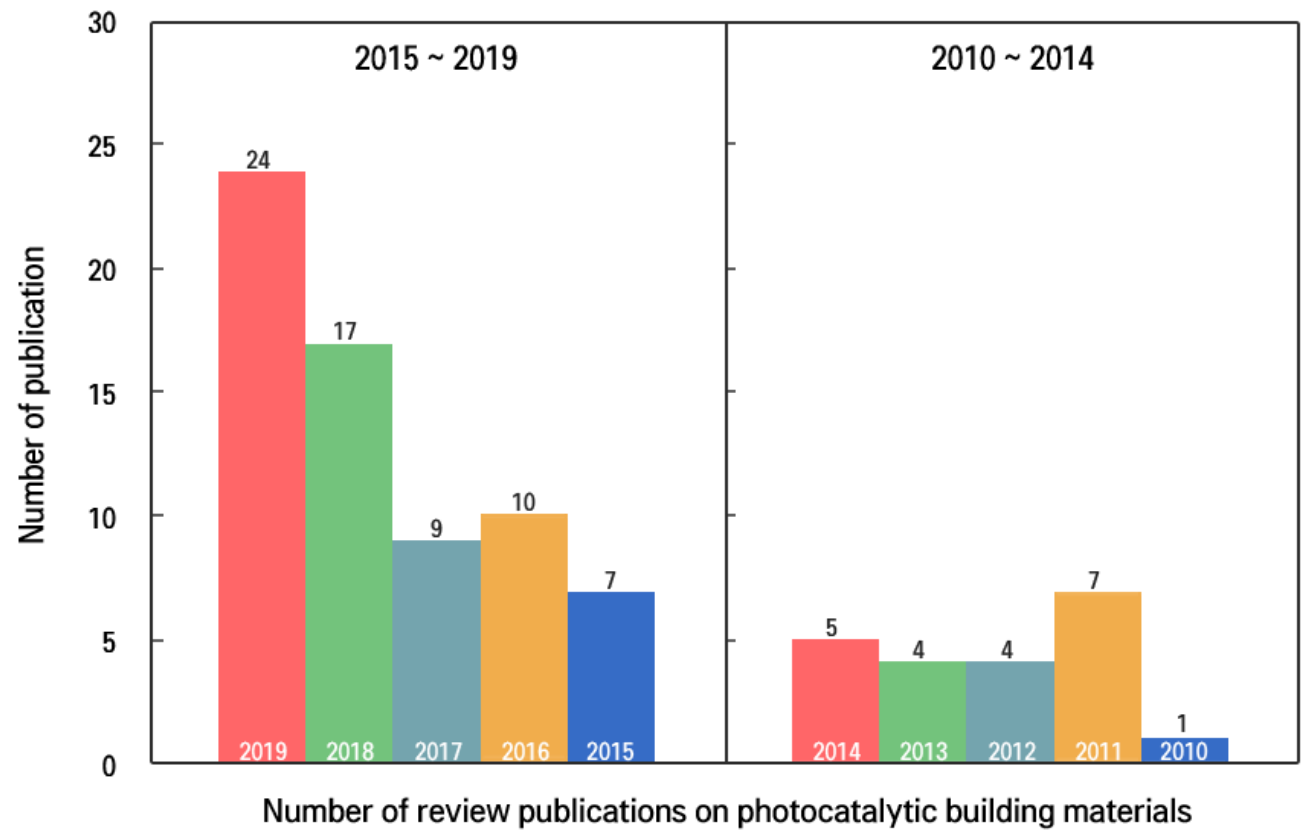

(b)

Scheme 2. (a) Several contributions published annually from 2010 to 2019 on $\mathrm{TiO}_{2}$-based photocatalytic materials in various sub-topics and (b) Number of published review articles annually from 2010 to 2019 for $\mathrm{TiO}_{2}$-based photocatalytic building materials.

On close perusal of the literature, we noticed that few review articles had been published in the recent period (2015-2019) on photocatalytic building materials (PBM), focusing on particular topics such as photocatalytic cement-based coatings [53], concrete nanotechnology [54], renewable 
photocatalysts in concrete [55], nano-inclusions applied in cement-matrices [56], indoor air purification by photocatalysts included concretes [55], etc. These reviews describe only a part of the discussion related to the utilization of $\mathrm{TiO}_{2}$ in building/construction materials (Scheme 3). Readers are advised to refer to the review published in 2009 to understand the development of photocatalytic construction and building materials focusing on three major research areas, including air purification, self-cleaning, and self-disinfection [57]. This particular review briefly describes the development of basic research and developments of $\mathrm{TiO}_{2}$-based photocatalysis in the field of construction and building materials.

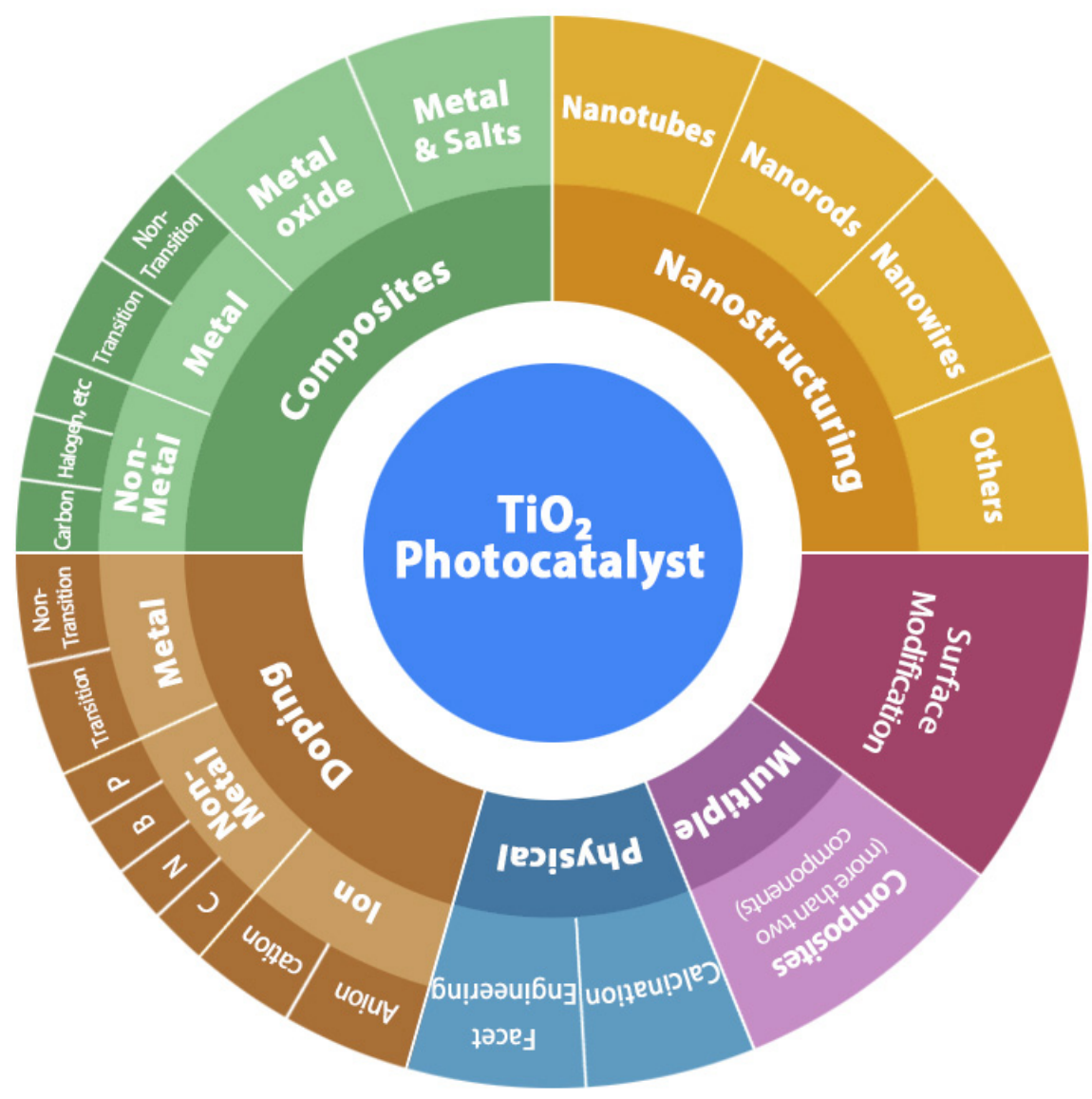

Scheme 3. Pictorial representation of the synthetic methodologies and modification strategies of the $\mathrm{TiO}_{2}$ photocatalyst.

A comprehensive report focusing on the utility of photocatalytic $\mathrm{TiO}_{2}$-based building materials, especially in the last few years (2015 to 2019), is highly warranted. Considering the importance of research activities on " $\mathrm{TiO}_{2}$ based building materials and related application" and the independent research developments that contributed to improving the photocatalytic properties of $\mathrm{TiO}_{2}$, such as enhanced photoactivity, an extension of visible-light photoactivity, etc., this review particularly focuses on the advancements of various kinds of $\mathrm{TiO}_{2}$-based building materials, such as cement, mortar, concrete, paints, etc., from 2015 to 2019. The review details the role of this $\mathrm{TiO}_{2}$-based building material with relevance to (i) $\mathrm{NO}_{x}$ removal, (ii) VOC photo-degradation, and (iii) self-cleaning surface developments, with sub-headings specifying the kind of building material, such as cement, concrete, mortar, and paint. At the end of the review, a summary of the research activities on $\mathrm{TiO}_{2}$-based building materials and directions for further research are presented.

\section{Building Materials}

Simple descriptions of some of the essential building materials (BM), such as cement, mortar, and concrete, are presented here for fair comparison among these materials. Lime is primarily comprised 
of calcium oxide $(\mathrm{CaO})$ and/or calcium hydroxide and/or calcium carbonate $\left(\mathrm{CaCO}_{3}\right)$, which can be obtained from the calcination of limestone (quick-lime) and hydrated lime. In a typical preparation of cement from limestone, a powder mixture comprising of limestone ( 70-90\%), clays $(\sim 5-20 \%)$, or alumina, bauxite, etc. (mostly $\mathrm{Al}_{2} \mathrm{O}_{3}$, or $\mathrm{Fe}_{2} \mathrm{O}_{3}$ and $\mathrm{SiO}_{2}$ ), silica $(\sim 3-10 \%)$, iron ore, or iron oxide $(\sim 1-5 \%)$ is heated to $\sim 1400{ }^{\circ} \mathrm{C}$ in a rotary kiln. During heating, the limestone decomposes to $\mathrm{CaO}$ beyond $900{ }^{\circ} \mathrm{C}$, which subsequently, with silica, forms dicalcium silicate $2 \mathrm{CaO} \cdot \mathrm{SiO}_{2}$ (referred to as $\mathrm{C}_{2} \mathrm{~S}$ in the notation of cement chemistry). Further, at temperatures above $1200{ }^{\circ} \mathrm{C}$, the components in the clay, such as $\mathrm{Al}_{2} \mathrm{O}_{3}$ and $\mathrm{Fe}_{2} \mathrm{O}_{3}$, as well as the iron component from iron ore, subsequently react with $\mathrm{CaO}$ and form the product tricalcium aluminate, $3 \mathrm{CaO} \cdot \mathrm{Al}_{2} \mathrm{O}_{3}$ (by notation as $\mathrm{C} 3 \mathrm{~A}$ ), and calcium aluminoferrite, $4 \mathrm{CaO} \cdot \mathrm{Al}_{2} \mathrm{O}_{3} \cdot \mathrm{Fe}_{2} \mathrm{O}_{3}$ (by notation as $\mathrm{C} 4 \mathrm{AF}$ ). Beyond $1250{ }^{\circ} \mathrm{C}$, the 'aluminate' minerals that exist in liquid form function as a medium to facilitate the reaction between dicalcium silicate and further $\mathrm{CaO}$ to form cement, tricalcium silicate $3 \mathrm{CaO} \cdot \mathrm{SiO}_{2}(\mathrm{C} 3 \mathrm{~S})$. The semi-liquid that is present at about $1300-1400^{\circ} \mathrm{C}$ can be further mixed with a cement linker (gypsum, others, etc.) to produce general-purpose cement or Portland cement. The terms cement and concrete are used interchangeably. However, cement is one of the ingredients of concrete. On the other hand, concrete comprises of aggregates, otherwise called gravel (sand and gravel or crushed stone), and paste (a mixture of water and cement). Mortar is another building material derived from cement that is composed of cement, fine sands, lime, and water. $\mathrm{TiO}_{2}$ or modified $\mathrm{TiO}_{2}$ materials can be included in any of the forms of building materials (cement, concrete, or mortar), and the chemical interactions among the components vary significantly, depending on the method of inclusion of $\mathrm{TiO}_{2}$ into these building materials.

Stone is one of the most widely used BMs since ancient times. Long-time exposure of historical constructions, sculptures, and monuments made of stone to weathering conditions and atmospheric pollution can cause a major change in the visual appearance of their surface or blackening of the architectural surfaces. Typically, the surface of the stone is subjected to deterioration over time due to various sources that include interaction with polluting gases and fine particulates. Most of these alterations mainly influence the visual appearance (aesthetics) of the stone itself, besides the loss of the original structural features of the stony material. In particular, research studies revealed that carbonate-based rocks, such as calcarenite and marble, are vulnerable to deterioration due to natural weathering and urban pollution. Also, biotic factors, such as the growth of microorganisms and biofilm formation, can cause degradation of stone surfaces and appearance. These issues can be fully or partially resolved by covering the surfaces of stony architectures with coatings. However, one must remember that a suitable coating for stone should introduce not only effective functions for stone protection, self-cleaning, and preservation of the aesthetic features of the original material, but should also be compatible with previous treatments and ensure stability and durability. It is worthwhile to note that the development of functional coatings with multiple properties, such as weather-resistance, self-cleaning, and a hydrophobic nature, is a promising challenge because of the wide variations in the chemical compositions of stones. A few reports pertinent to the application of $\mathrm{TiO}_{2}$ photocatalysis and the related phenomenon of stone coating for preservation are detailed below.

Studies have been focused on the development of functional coatings based on $\mathrm{TiO}_{2}$ nanoparticles (NPs) in the process of protecting lapideous (texture of stone) building materials in monuments and artworks of historical and architectural nature [58,59]. The coatings based on $\mathrm{TiO}_{2} \mathrm{NPs}_{\text {for }}$ cultural heritage conservation need to comply with multiple requirements. Functional $\mathrm{TiO}_{2} \mathrm{NPs}_{\text {s }}$ based coatings have shown multiple capabilities that include prevention of the bio-deterioration of stony surfaces [60], controlling the formation of black crusts and salts [61], and conferring hydrophobic properties to the surface for reducing the percolation/penetration of water into the pores without affecting the aesthetic appearance [59]. The coating formulation can be made through two different approaches. In the first formulation, $\mathrm{TiO}_{2} \mathrm{NPs}$ can be incorporated in a commercial polymer host matrix that can be used as a cleanser, protector, or consolidant. The second approach involves the direct application of $\mathrm{TiO}_{2} \mathrm{NPs}$ onto the stone surface through spray coating. The second approach presents several advantages (using suitable formulations), such as retaining the photocatalytic activity, 
preserving the aesthetic appearance of the stone surface, and formation of a uniform surface [62]. In this regard, aqueous and alcoholic suspensions of $\mathrm{TiO}_{2} \mathrm{NPs}$ have been applied to porous and compact limestones $[63,64]$. $\mathrm{TiO}_{2}$-based coatings with NP sizes in the range of 10-20 nm were applied through spray coating, resulting in a uniform coating with photocatalytic activity and the preservation of the stone's aesthetics [65]. Mesoporous anatase $\mathrm{TiO}_{2}$-based coating dispersion in ethylene glycol was applied onto Noto stone and Carrara marble surfaces, and the aesthetic compatibility, capillary absorption coefficient, and photocatalytic activity were reported to be significantly improved [66]. The coating based on $\mathrm{TiO}_{2} \mathrm{NPs}^{\prime}$ dispersion in chloroform was tested on stony materials and the NPs were surface functionalized for improving their dispersibility in the solvent [67]. Other approaches, such as casting and dipping, were attempted for photocatalytic $\mathrm{TiO}_{2}$ nanorod-based coatings on Lecce stone surfaces [67]. The spray coating was reported to be cost-effective for obtaining thin and crack-free films which were highly stable on the stone surface [68,69]. Another study has shown that coatings based on $\mathrm{TiO}_{2} \mathrm{NPs}$ on stones induced a photocatalytic self-cleaning effect on the surfaces [70].

\section{Integration of Photocatalyst on Building Materials}

This heading details the key factors that involve the integration of $\mathrm{TiO}_{2}$ photocatalysts with $\mathrm{BMs}$ : the preparation of $\mathrm{TiO}_{2}$, the $\mathrm{BM}$ component to be integrated (e.g., cement, concrete, etc.), and the process steps. Each one of the key factors for the integration of a $\mathrm{BM}_{\text {with }} \mathrm{TiO}_{2}$ contributes to the final photoactivity and performance of the fabricated materials. Firstly, the selection of $\mathrm{TiO}_{2} \mathrm{NPs}$ with adequate physico-chemical characteristics (size, phase composition, morphology, and surface area) is a core part of their integration into a BM. The process step in the integration can either be mixing or dispersing $\mathrm{TiO}_{2}$ into the $\mathrm{BM}$ matrix, and this step determines the uniformity and the physico-chemical properties of the $\mathrm{TiO}_{2}$ integrated $\mathrm{BM}$. The mixing process can be categorized as either synchronous or latter ad-mixing, depending on the stage at which the mixing of $\mathrm{TiO}_{2}$ is performed. However, the mixing process for the integration of $\mathrm{TiO}_{2}$ with a $\mathrm{BM}$ is constrained with the problem of agglomeration of particles, irrespective of the mixing methodology adopted. Mostly, the smaller sizes and the high surface energy of $\mathrm{TiO}_{2}$, as well as the Brownian motion of the smaller particles, can cause particles to agglomerate. The agglomeration of $\mathrm{TiO}_{2}$ particles can not only reduce their photoactivity but also their mechanical strength by blocking access to the internal surface of $\mathrm{TiO}_{2}$.

Alternatively, the dispersion technique can be a better approach for resolving agglomeration problems. The bead or ball milling technique has been attempted to disperse NPs [71]. However, the problem involved in bead milling is the difficulty of handling the process with slurries having high solid fractions. The ball milling method has advantages, such as low cost, environment-friendly approach, high efficiency and controllability with the parameters, and large scale applicability in industries [72,73]. Ultrasonic irradiation can be another process step for the dispersion of submicrometer sized particles, which can eliminate the agglomeration problem [74,75]. The agglomeration of particles can be prevented by the shock waves generated from ultrasonic irradiation and collapsing cavitations, which causes the agglomerated particles to split due to the collisions. However, ultrasonic dispersion is an expensive technique as it is energy-intensive. To circumvent aggregation problems, the utilization of water-reducing admixtures (plasticizers and superplasticizers) and surfactant treatments have been attempted [76,77]. Surface potential (zeta potential) modulation can be used to prevent the agglomeration of $\mathrm{TiO}_{2}$ particles. For example, the zeta potential of cement mortar is the measure of the degree of repelling between particles, and indicates the surface charge states. Zeta potential values lower than $-30 \mathrm{mV}$ and higher than $+30 \mathrm{mV}$ can be used as guidelines for preventing agglomeration [78]. Importantly, under the condition that the charges of the added $\mathrm{TiO}_{2}$ particles and mortars are similar, agglomeration can be minimal, as the particles of each sort are supposed to repel each other. One must note that zeta potential measurements of cementitious materials have generally been done with a low fraction of solids, hence it is challenging to conclude information about the zeta potential values of fresh cement mortars and photocatalytic cement mortars. Recently, spray coating has been tried to create a surface coating on stone or building surfaces [79]. The spray coating formulation was developed 
based on nitrogen-doped $\mathrm{TiO}_{2}$ using a silane coupling reagent, and the coating durability was around 13 months [80] This review mainly focuses on the photocatalytic pollutant removal performance of $\mathrm{TiO}_{2}$-loaded BMs and the durability, mechanical strength, and lifetime issues of the integrated materials. There are controversial reports on the durability and mechanical effects of added $\mathrm{TiO}_{2}$ into BMs. While it has been reported that nano $\mathrm{TiO}_{2}$ is chemically inert in the process of cement hydration, it has also been suggested that it can provide crystal nuclei to promote cement hydration, causing an increase in the compressive strength of mortars [81] Additionally, it has been reported that high brittleness and internal cracks that could be generated due to photocatalyst inclusion are the reasons for the decline in photocatalytic performance and service life of building materials. Readers are advised to refer to the forthcoming sections that deal with uses of $\mathrm{TiO}_{2}$-integrated $\mathrm{BMs}$ for specific environmental pollutant removal and self cleaning. Also, it should be noted that the PBMs generated through the integration of $\mathrm{TiO}_{2}$ with any of the building material constituents should withstand the harsh and aggressive environments in which they are put into use. These requirements are dependent on the strength and durability of the resultant PBMs.

\section{4. $\mathrm{TiO}_{2}$ Photoactivity under Solar Light}

$\mathrm{TiO}_{2}$ exists in three different polymorphs: anatase, rutile, and brookite, with a bandgap of $3.2 \mathrm{eV}$ for anatase, $\sim 3.0 \mathrm{eV}$ for rutile, and $\sim 3.2 \mathrm{eV}$ for brookite $[82,83]$. The bandgap of anatase corresponds to a wavelength of $388 \mathrm{~nm}$, signifying that photo-activation of anatase can happen under irradiation of light with a wavelength lower than $388 \mathrm{~nm}$. Therefore, visible light irradiation is not able to trigger the photocatalytic activity in anatase [84-86]. Recently, there is a growing interest in sunlight-driven photocatalytic applications, considering the fact that the UV fraction of the solar spectrum is limited to $\sim 4 \%$; on the other hand, significant proportions of photons can be generated from the visible region (early 50\%).

Various strategies have been employed to make $\mathrm{TiO}_{2}$ a visible light active material [87]. The techniques/methodologies include surface modification via organic materials, mixing with other visible light active semiconductors, tuning the bandgap by creating oxygen vacancies and doping with metal/nonmetals, and co-doping of nonmetals and metals. Doping elements, such as S, C, N, and $\mathrm{B}$, can create interband energy states between valence and conduction bands, or lower the bandgap and thus extend the visible light absorption capacity of $\mathrm{TiO}_{2}$ [88]. The non-metal dopants could substitute the oxygen atoms from the lattice of $\mathrm{TiO}_{2}$, create oxygen vacancies, and lower the bandgap. Similarly, noble metals and other semiconductors can form heterojunctions with $\mathrm{TiO}_{2}$ and enhance the photocatalytic activities of $\mathrm{TiO}_{2}$ [86,89-91]. Readers are advised to refer to the published reviews on the mechanism of visible light activity induction and the methodology of modification of $\mathrm{TiO}_{2}$ for achieving visible light activities [92-97]. It must be noted that, keeping in mind the fact that sunlight is the natural source for an enormous proportion of visible light, research is focused on harnessing sunlight to meet the urgent demand for a cleaner environment. Architects and structural engineers are directing their attention towards the development of advanced photocatalytic BMs with the utilization of sunlight. These functionally engineered structural materials are expected to be utilized for resolving environmental pollutant removal issues in an economic and efficient way. Of course, this area of research is in its infancy. Few reports have demonstrated the potential use of visible light active $\mathrm{TiO}_{2}$-inclusive $\mathrm{BMs}$ for environmental remediation, and the details are distributed in the forthcoming subheadings dealing with individual cases of pollutant removal. However, marketability, cost of production, and ease of preparation need to be optimized by extensive research in these directions. The ultimate purpose of the incorporation of $\mathrm{TiO}_{2}$ into these building materials is to derive photocatalytic properties for the resultant materials. The following paragraphs provide significant research developments that occurred during the years between 2014 and 2019 on $\mathrm{TiO}_{2}$-inclusive building materials to achieve the desired $\mathrm{NO}_{\mathrm{x}}$ removal photocatalytic properties. 


\section{5. $\mathrm{NO}_{x}$ Removal}

$\mathrm{NO}_{\mathrm{x}}$ is generally a collective term that represents two distinct gases, namely $\mathrm{NO}$, or nitric oxide, and $\mathrm{NO}_{2}$, or nitrogen dioxide, and the gradual oxidation of $\mathrm{NO}$ results in nitric acid and $\mathrm{NO}_{2}$. Nitrous acid is a possible intermediate during the transformation of $\mathrm{NO}$ to $\mathrm{NO}_{2}$. It is to be mentioned that intermediates are more harmful than the primary reactants, $\mathrm{NO}$ and $\mathrm{NO}_{2}$ [98]. Specifically, $\mathrm{NO}_{2}$ is three times more toxic than $\mathrm{NO}$, the primary pollutant [99]. $\mathrm{NO}_{2}$ can function as a precursor for the generation of even more toxic atmospheric constituents, such as ozone and peroxyacyl nitrates. In addition, $\mathrm{NO}_{\mathrm{x}}$ can interact with other primary pollutants, such as $\mathrm{PM}$ or $\mathrm{SO}_{\mathrm{x}}$ (sulfur dioxide and sulfur trioxide), and can generate other problems, such as ozone, acid rain formation, etc. Thus, $\mathrm{NO}_{\mathrm{x}}$ emission forms the basis of formulating environmental regulations, especially in the ozone non-attainment areas. $\mathrm{NO}_{\mathrm{x}}$ pollutants are introduced into the ecosystem through natural (extreme heat of lightning), biogenic (fertilization and the use of nitrogen-fixing plants), and industrial (thermal natural combustion, fuel combustion, and prompt process) sources. The probable sources of $\mathrm{NO}_{\mathrm{x}}$ and the health issues arising from short-term and long-term exposure are presented in Scheme 4. Due to the environmental damage caused by $\mathrm{NO}_{x}$ gases, many regulations were designed to limit their emissions. The emission regulations vary from country to country in type and extent. The concentration limit for $\mathrm{NO}_{x}$ to cause pollution in ambient air as per the European directive is $40 \mathrm{~g} \cdot \mathrm{m}^{-3}(0.021 \mathrm{ppmv})$ averaged over one year and $200 \mathrm{~g} \cdot \mathrm{m}^{-3}(0.106 \mathrm{ppmv})$ averaged over $1 \mathrm{~h}$ (Directive 2008/50/EC, 2008) [100]. Likewise, the $\mathrm{NO}_{\mathrm{x}}$ concentration limits fixed by other authorities, such as WHO, the U.S. Environmental Protection Agency, the Ministry of Environmental Protection of China, and the Australian Department of the Environment and Energy, are similar.

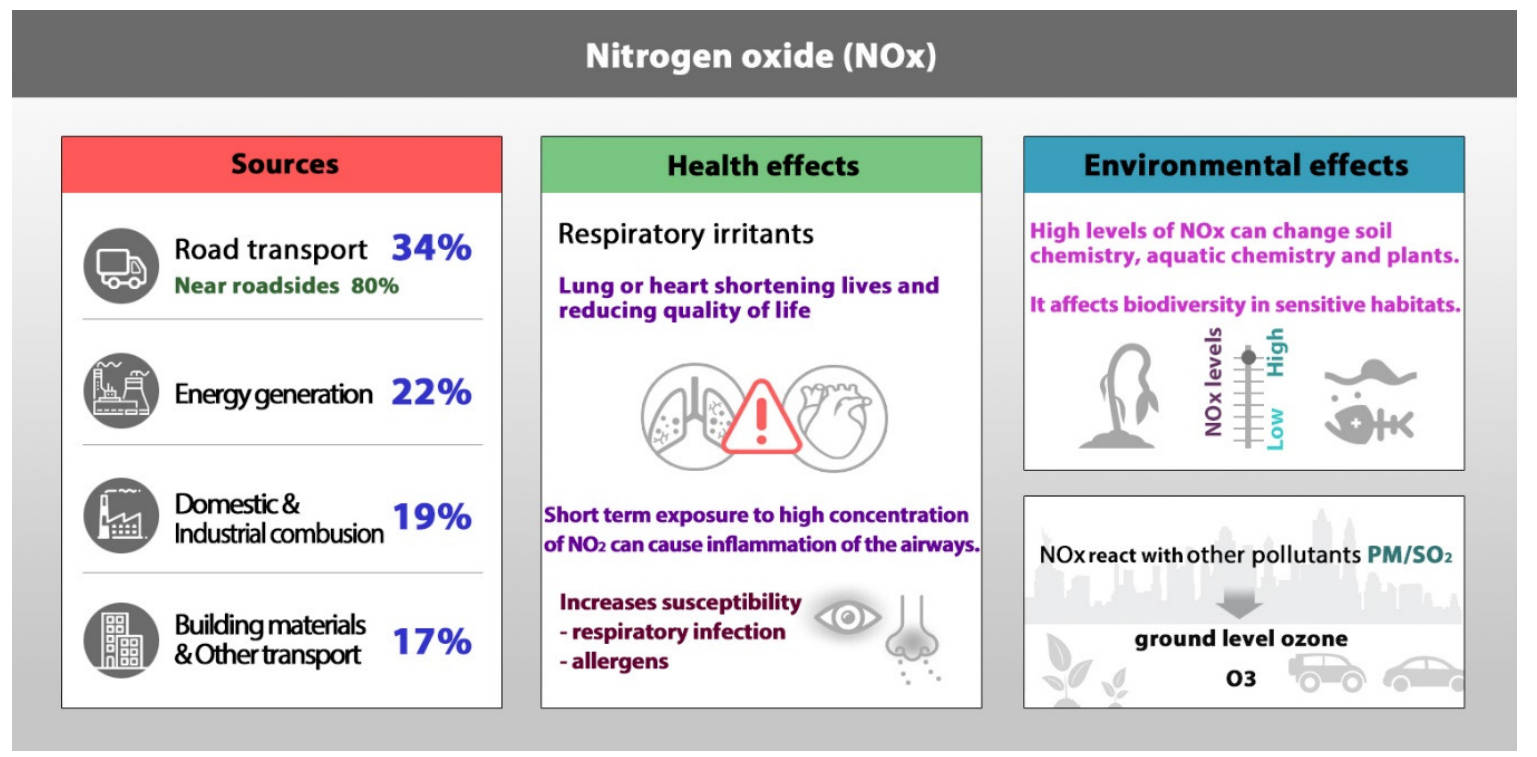

Scheme 4. The potential sources and health and environmental effects of $\mathrm{NO}_{\mathrm{x}}$.

Mitigation or removal of $\mathrm{NO}_{x}$ can be done through primary and secondary procedures (Scheme 5). Conventional $\mathrm{NO}_{\mathrm{x}}$ control measures through primary strategies include a selective catalytic reduction (SCR), selective non-catalytic reduction, adsorption, scrubbing (absorption), etc. Traditional systems are constrained by the higher expenses involved, especially for the treatment of sufficiently larger volumes of air comprised of low to moderate concentrations of $\mathrm{NO}_{\mathrm{x}}$. Besides, conventional systems generate secondary waste, and hence often require further processing. $\mathrm{NO}_{\mathrm{x}}$ control methodology focuses on either the reduction of $\mathrm{NO}_{x}$ back to the parent compound $\mathrm{N}_{2}$ or its oxidation to $\mathrm{HNO}_{3}$. PCO of $\mathrm{NO}_{x}$ offers the following distinctive advantages: (1) non-requirement for extra reactants, and (2) conversion of $\mathrm{NO}_{\mathrm{x}}$ into nitric acid, a potential raw material for fertilizers. Heterogeneous photocatalysis, which is particularly efficient, includes three different processes: photodecomposition, 
photooxidation, and photo-selective catalytic reduction. The photocatalytic conversion of $\mathrm{NO}_{\mathrm{x}}$ to nitric acid comprises a sequential or series of the oxidation process. Higher catalytic activity is ensured by a higher degree of $\mathrm{NO}$ and $\mathrm{NO}_{2}$ conversions.

$$
\mathrm{NO} \rightarrow \mathrm{HNO}_{2} \rightarrow \mathrm{NO}_{2} \rightarrow \mathrm{HNO}_{3}
$$



Scheme 5. Common strategies (primary and secondary) employed for $\mathrm{NO}_{\mathrm{x}}$ removal. (FLOX: flameless oxidation; COSTAIR: continuous staged air combustion; GAFT: gas-dynamic abated flame temperature).

However, the photogenerated charge carriers on the catalyst surface can also stimulate reduction processes. The efficiency of the reduction process of $\mathrm{NO}_{2}$ to $\mathrm{HONO}$ depends on the reduction capability of the photocatalyst as well [101].

One should note that there is a definite possibility of the generation of $\mathrm{NO}_{\mathrm{x}}$ in residential (indoor) conditions. Therefore, the quality of indoor air is a matter of concern. It can be noted that an indoor $\mathrm{NO}_{\mathrm{x}}$ level of more than $200 \mathrm{pg} / \mathrm{m}^{3}(0.1 \mathrm{ppm})$ may be reached through $\mathrm{NO}_{\mathrm{x}}$ generated from unvented gas combustion appliances, and an hourly peak $\mathrm{NO}_{\mathrm{x}}$ level may be $2000 \mathrm{pg} / \mathrm{m}^{3}$ (1 ppm), with a maximum-per-minute peak of $4000 \mathrm{pg} / \mathrm{m}^{3}(2.1 \mathrm{ppm})$. In the case of short-term exposure for healthy individuals, $\mathrm{NO}_{\mathrm{x}}$ concentrations of more than $4700 \mathrm{pg} / \mathrm{m}^{3}(2.5 \mathrm{ppm})$, either at rest or with around $2 \mathrm{~h}$ of light exercise, can result in pulmonary dysfunction. With regards to long-term exposure (several weeks to months), indoor $\mathrm{NO}_{\mathrm{x}}$ exposure of nitrogen dioxide with concentrations of less than $1880 \mathrm{pg} / \mathrm{m}^{3}$ $(1 \mathrm{ppm})$ can cause a large number of health effects, primarily in the lungs and other organs, such as the spleen and liver. Notably, long-term exposure to $\mathrm{NO}_{\mathrm{x}}$ can cause reversible and irreversible lung effects. Typically, the impact on the lungs can vary depending on the level of $\mathrm{NO}_{\mathrm{x}}$ exposure and duration. A low-level $\mathrm{NO}_{\mathrm{x}}$ exposure of as low as $940 \mathrm{pg} / \mathrm{m}^{3}(0.5 \mathrm{ppm})$ may also lead to bacterial infection of the lungs [102].

Few efficient methods have been evolved to minimize the level of indoor $\mathrm{NO}_{\mathrm{x}}$ emissions inside buildings by utilizing photocatalysis of $\mathrm{TiO}_{2}$. The general photocatalytic mechanism involving a sequence of reactions upon irradiation of $\mathrm{UV}$ light with $\mathrm{TiO}_{2}$ (either pristine or in the form of a building material) is as follows: the exposure of the $\mathrm{TiO}_{2}$ surface to a UV light excites the electrons in the valence 
band (VB) to the conduction band (CB) and, in that process, holes are left in the VB. The generated charge carriers, electrons, and holes subsequently participate in the oxidation-reduction (redox) reactions for $\mathrm{NO}_{x}$ degradation. In principle, the generally proposed mechanism of $\mathrm{NO}_{x}$ photocatalytic oxidation consists of three stages: reaction between $\mathrm{NO}$ and photogenerated $\mathrm{OH}$ radicals which results in $\mathrm{HNO}_{2}$ at the surface of $\mathrm{TiO}_{2}$ (first stage), transformation of $\mathrm{HNO}_{2}$ to $\mathrm{HNO}_{3}$ and desorption from the surface of $\mathrm{TiO}_{2}$ (second stage), and regeneration of the photocatalyst $\left(\mathrm{TiO}_{2}\right)$ (third stage). The mechanisms involved in these stages of reactions were well detailed by several researchers $[100,103]$. In this context, a large number of research activities resulted in newly developed/synthesized $\mathrm{TiO}_{2}$-based materials that can be applied to buildings in the form of a coating or paint, or mixing with mortar, which will further enhance building aesthetics, sanitation, etc. Considering the advantages of including $\mathrm{TiO}_{2}$ into building materials, a flurry of activities has attracted many industrial interests. Several forms of $\mathrm{TiO}_{2}$-inclusive building materials, such as concrete pavements, eco-friendly cement (TioCem), and an architectural concrete (white cement), have been evaluated and patented [104-106]. Subsequently, photocatalytic paints including $\mathrm{TiO}_{2}$ in different kinds of binders, such as lime, polysiloxane, and sol-gel derived silica materials, are most frequently used. The forthcoming headings will describe the importance of $\mathrm{TiO}_{2}$-inclusive cement, mortar, concrete, paint, and coatings for $\mathrm{NO}_{\mathrm{x}}$ removal.

Lettieri et al. investigated the influence of colloidal suspensions of $\mathrm{TiO}_{2} \mathrm{NPs}$ with $1 \%$ and $2 \mathrm{wt}$. $\%$ concentrations and evaluated their $\mathrm{NO}_{x}$ depolluting abilities by coating them onto the limestone surface [107]. For this purpose, two limestones, namely a compact limestone (PT-Trani stone) and a soft and highly porous limestone (PL-Lecce stone), were utilized. The PL-based surface exhibited higher $\mathrm{NO}_{x}$ photo-degradation efficiency than the PT stone-based one under a UV lamp. About $60 \%$ of $\mathrm{NO}_{\mathrm{x}}$ removal was observed over a period of $30 \mathrm{~min}$ of exposure over the photocatalytic material coated PL stones (Figure 1). A conclusion was reached with regards to the high $\mathrm{NO}_{\mathrm{x}}$ removal efficiency derived from $\mathrm{TiO}_{2}$-inclusive limestones: the higher surface roughness and porosity of the limestone surface provided an environment for the formation of an extensive exterior surface layer of $\mathrm{TiO}_{2} \mathrm{NPs}$. The study also revealed an inadequate reduction of $\mathrm{NO}_{\mathrm{x}}$ when low porous limestone was used for preparation through alcoholic solutions.

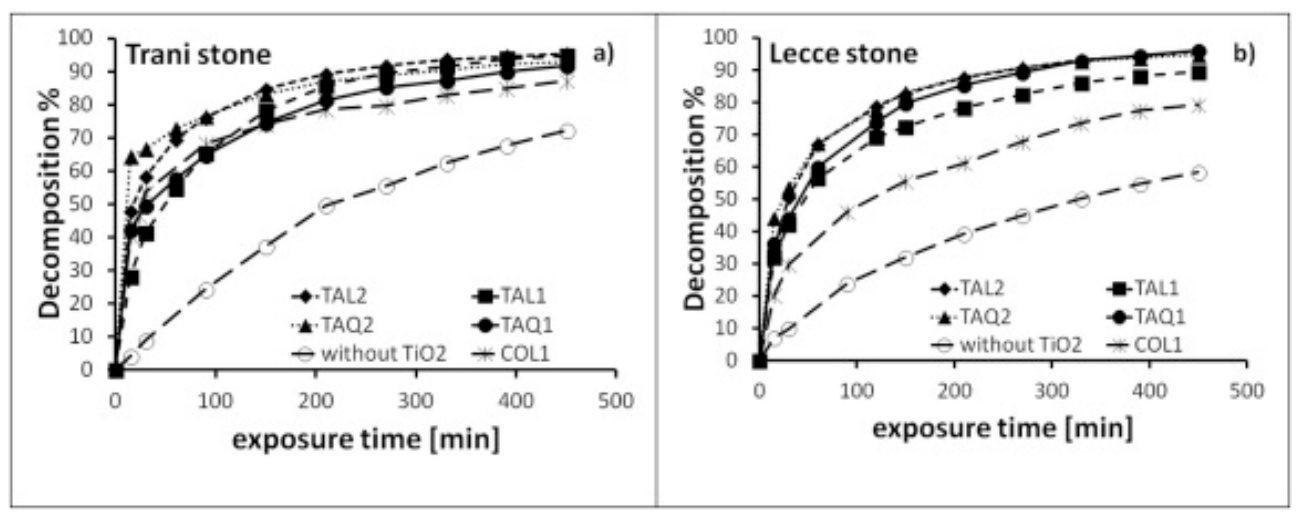

Figure 1. Decomposition rate of Rhodamine B for (a) Trani stone and (b) Lecce stone as a function of irradiation time [107]. (T: tetrapropylorthotitanate, AL: alcohol, and AQ: aqueous (water). TAL refers to a combination of $\mathrm{T}$ and $\mathrm{AL}$ in preparation condition, and TAQ refers to the combination of $\mathrm{T}$ and water.

In a subsequent investigation, the photocatalytic performances of limestone surfaces covered with a coating of water dispersed $\mathrm{TiO}_{2} \mathrm{NPs}$ were evaluated in an urban environment (Bari, a port city in southeastern Italy from February 2016 to January 2017) (Figure 2) [108]. Data were collected by evaluating the concentrations of air pollutants $\left(\mathrm{PM}, \mathrm{NO}_{x}, \mathrm{CO}\right.$, and benzene) in urban environmental conditions at the exposure site on a daily average basis for the varying climatic parameters (temperature, rain, wind, and light exposure). The daily mean values for $\mathrm{NO}_{\mathrm{x}}$ concentrations ranged from 50 to $110 \mu \mathrm{g} / \mathrm{m}^{3}$, with an average of $73 \mu \mathrm{g} / \mathrm{m}^{3}$. The other vital results on $\mathrm{NO}_{\mathrm{x}}$ removal were as follows: 
$\mathrm{NO}_{2}$ daily mean concentrations were between 30 and $60 \mu \mathrm{g} / \mathrm{m}^{3}$, with an annual average of $45 \mu \mathrm{g} / \mathrm{m}^{3}$. The results were assessed based on the European Union (EU) limit values for $\mathrm{NO}_{2}$ concentrations. As per the EU's suggestion, $\mathrm{NO}_{\mathrm{x}}$ removal concentrations of annual mean and $18 \mathrm{~h}$ mean per year were considered as $40 \mu \mathrm{g} / \mathrm{m}^{3}$ and $200 \mu \mathrm{g} / \mathrm{m}^{3}$, respectively [109].

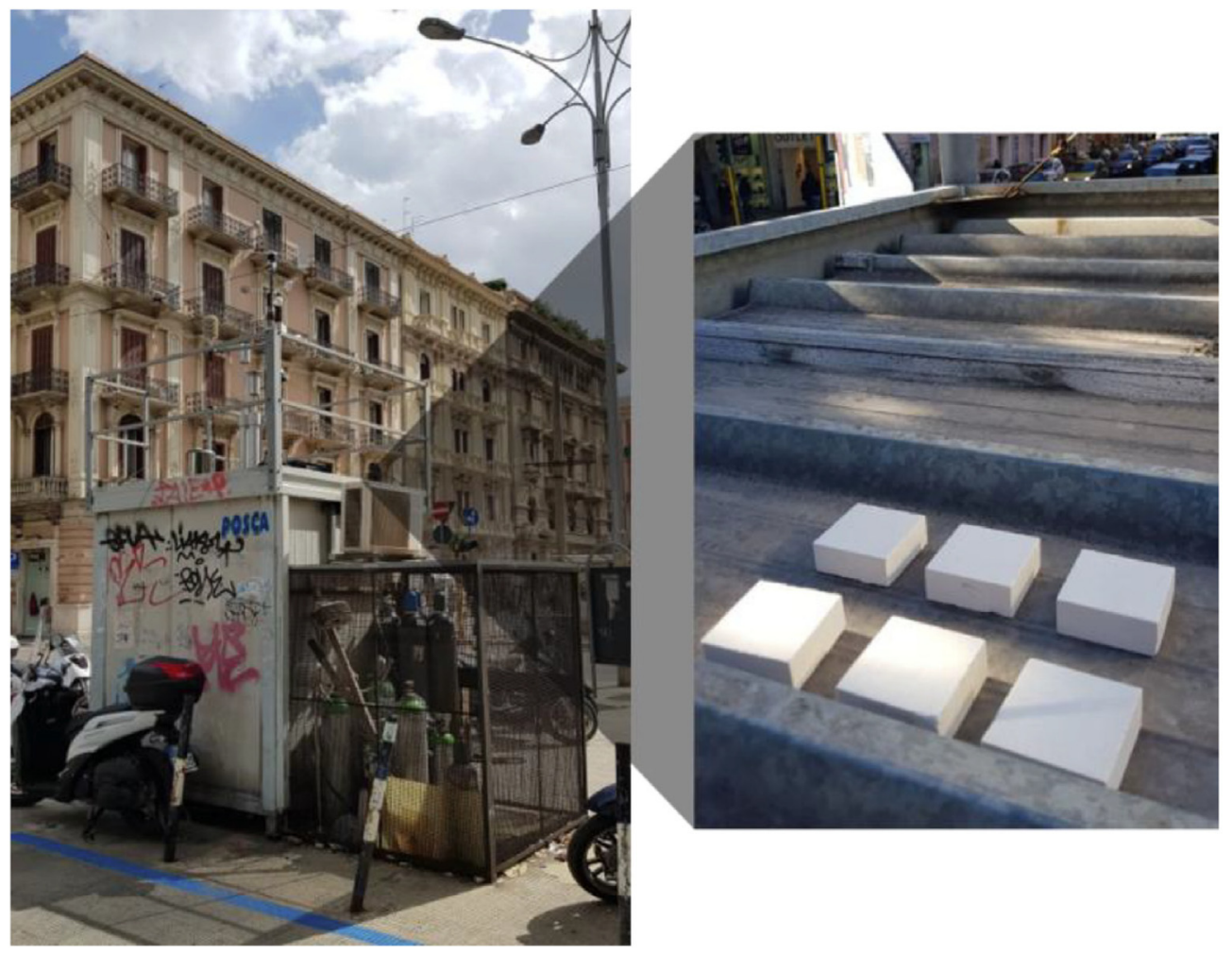

Figure 2. Samples exposed on top of the ARPA (Regional Agency for Environmental Protection) [108].

It was concluded that surface color properties could be preserved after $\mathrm{NO}_{\mathrm{x}}$ exposure through $\mathrm{TiO}_{2}$ coating, and the coating's effect was lost after eight months with the concomitant decrease in self-cleaning. The utility of a photocatalytic concrete overlay was evaluated in terms of the combined effects of energy conservation in the building, vehicular pollutant removal, and urban heat island (UHI) effect. These effects were compared between gray and white cement, along with a reference to cement without $\mathrm{TiO}_{2}$. The environmental benefits of the photocatalytic concrete were inferred in terms of concluding the pavement life cycle assessment (LCA) $[109,110]$.

The $\mathrm{TiO}_{2}$-inclusive photocatalytic concrete was effective for $\mathrm{NO}_{\mathrm{x}}$ removal, which in turn resulted in a decrease in acidification, ecotoxicity, eutrophication, human health degradation factors, smog formation, and respiratory effects. Pollutant removal studies informed that white cement-based photocatalytic materials were superior for $\mathrm{NO}_{x}$ removal than gray cement. A microscale thermal model was proposed to explain the UHI effect arising from white cement concrete overlays. The model suggested a five-fold reduction in global warming potential for white cement as compared to gray cement. Through the design of a small scale bed flow photoreactor, the photocatalytic performances of cement-based $\mathrm{TiO}_{2}$-containing materials were evaluated towards $\mathrm{NO}_{\mathrm{x}}$ reduction by monitoring the potential reaction products from the gas phase/aqueous extraction for various experimental conditions (relative humidity, flow rate, mixing ratio, and light intensity) [111]. The results revealed that the potential of the cement-based $\mathrm{TiO}_{2}$-containing materials towards photocatalytic remediation of $\mathrm{NO}_{\mathrm{x}}$ and conversion into nitrite through the analysis of reaction products at the surface. Under atmospheric conditions, the $\mathrm{NO}$ and $\mathrm{NO}_{2}$ uptake coefficients were determined in the range of $5 \times 10^{-5}$ at a surface deposition velocity of about $0.5 \mathrm{~cm} / \mathrm{s}$. The $\mathrm{NO}_{\mathrm{x}}$ removal capacity of photocatalytic blocks of cement, based on mortars made with Portland cement, two different calcium aluminate types of cement, and air 
lime, and at least a few $\mathrm{TiO}_{2}$ additives $\left(\mathrm{TiO}_{2}\right.$ as reference catalyst, and two doped titania, $\mathrm{Fe}-\mathrm{TiO}$, and $\mathrm{V}-\mathrm{TiO}_{2}$ ), was investigated [112]. A high $\mathrm{NO}_{x}$ abatement (up to 60-80\%) with good selectivity was observed for air lime and high alumina cement (HAC) mortar-based photocatalytic cement under the three illumination conditions (UV, solar, and visible light). Lime and HAC mortars exhibited the best $\mathrm{NO}_{\mathrm{x}}$ abatement percentages under the three irradiation conditions (UV, solar and visible lights). The $\mathrm{NO}_{x}$ removal efficiency was explained through the combined influence arising from the presence of higher amounts of calcium carbonate and the probable reaction of the final photo-degradation product of $\mathrm{NO}_{x}$, namely nitric acid. The additional role of visible light photo-degradation was proven by the increase in $\mathrm{NO}$ removal percentages of the mortars with the doped additives $\left(\mathrm{Fe}-\mathrm{TiO}_{2}\right.$ and $\mathrm{V}-\mathrm{TiO}_{2}$ ). Among the doped $\mathrm{TiO}_{2}$ samples, $\mathrm{Fe}-\mathrm{TiO}_{2}$ was most effective for $\mathrm{NO}_{\mathrm{x}}$ removal. Dawa Seo and Tae Sup Yun compared the nitrogen monoxide (NO) removal capacity of $\mathrm{TiO}_{2}$-inclusive cementitious materials between wet and dry conditions [113]. An experimental design was made as shown in Figure $3 \mathrm{a}, \mathrm{b}$. The wetting of the photocatalytic cement-based materials and the wetting condition play critical roles in achieving a reasonable NO removal rate and also to understand practical sustainability against air pollution. The water molecules were present near $\mathrm{TiO}_{2}$ particles, and the wetting altogether influenced the photocatalytic reactions (Figure 3c). The increase in humidity and the rewetting of $\mathrm{TiO}_{2}$ occurred through the continuous evaporation of vaporized water molecules from pores.

Aqueous suspensions of $\mathrm{TiO}_{2}$ NP-based photocatalytic surface coatings were developed as a user-friendly approach for cementitious surfaces, and a remediation technique for $\mathrm{NO}_{\mathrm{x}}$ emission and organic pollutant removal was developed [114]. Hydrophobic and hydrophilic photocatalytic $\mathrm{TiO}_{2}$ sols were used for dip coating as well as spray coating on the cement tiles, and $\mathrm{NO}_{\mathrm{x}}$ removal efficiencies were evaluated. Hydrophobic photoactive $\mathrm{TiO}_{2}$ NP-based coatings exhibited an excellent ability to convert NO gas when applied on the concrete surfaces. About a $90 \%$ reduction in $\mathrm{NO}_{\mathrm{x}}$ pollutants was evident from hydrophobic $\mathrm{TiO}_{2}$ coated cement tiles for $\mathrm{TiO}_{2}$ loadings above $5 \%$, which suggested that the coating can be beneficial for highly polluted areas near pollution sources. The photocatalytic degradation ability for pollutants and the binding efficiency of cement containing $\mathrm{TiO}_{2} \mathrm{NPs}_{\mathrm{S}}$ were investigated under nitric oxide and nitrogen dioxide gas exposures in the presence and absence of ultraviolet (UV) light. The photocatalytic efficiency was determined to understand the effect of the different water-to-cement ratios (w/c) of the cementitious materials. Based on the results, a mechanism for photocatalytic $\mathrm{NO}_{x}$ removal while using hardened cement was proposed (Figure 4 ). The mechanism involves the adsorption of $\mathrm{NO}_{2}$ gas molecules onto hardened cement paste structures, the occurrence of hydrolysis of $\mathrm{NO}_{2}$ into the pores, and the formation of soluble nitrates [115]. These experimental results demonstrated that cementitious materials could be tailored to decrease $\mathrm{NO}_{\mathrm{x}}$ levels through photocatalysis and showed their ability to bind $\mathrm{NO}_{\mathrm{x}}$, in particular, $\mathrm{NO}_{2}$. The study was designed based on the fact that variation in the water-to-cement ratio can alter the pore structure (i.e., pore volume, size distribution, and interconnectivity) of cementitious materials, which in turn alters the proportion of effective surface area available for PCO and adsorption/binding of by-products.

The $\mathrm{TiO}_{2}$-inclusive self-compacting glass mortar (SCGM) was developed for evaluating photocatalytic $\mathrm{NO}_{\mathrm{x}}$ degradation [116]. Recycled broken glass pieces from a local glass beverage bottle were used as the aggregate. While $\mathrm{HNO}_{3}$ is the generally expected final photocatalytic $\mathrm{NO}_{x}$ degradation product from cementitious materials, SCGM produces $\mathrm{NO}_{2}{ }^{-}$in place of $\mathrm{NO}_{3}{ }^{-}$as the major $\mathrm{NO}_{x}$ photo-degradation product [117]. The $\mathrm{NO}_{2}$ changed to $\mathrm{HONO}$ in the atmosphere and caused the generation of secondary pollutants through the photochemical reaction. Based on the use of SCGM-based materials for $\mathrm{NO}_{\mathrm{x}}$ degradation, it has been inferred that SCGM is not as useful as studies expected for high photocatalytic $\mathrm{NO}_{x}$ removal efficiency and high conversion efficiency of $\mathrm{NO}^{-} \mathrm{NO}_{3}{ }^{-}$. Such difficulty in achieving the targeted photo-degradation efficiency demands research on SCGM. 
Dry specimen $\rightarrow$ Dry condition

(a)

\begin{tabular}{c|c|c|}
\multicolumn{2}{c}{ Specimen in } \\
\multirow{2}{*}{ UV lamp } & off & No absorption \\
\cline { 2 - 3 } Time & 30 minutes & on \\
\cline { 2 - 3 } & & 30 minutes
\end{tabular}

Saturated specimen $\rightarrow$ Wet condition

(b)

Measure NO concentration

Measure

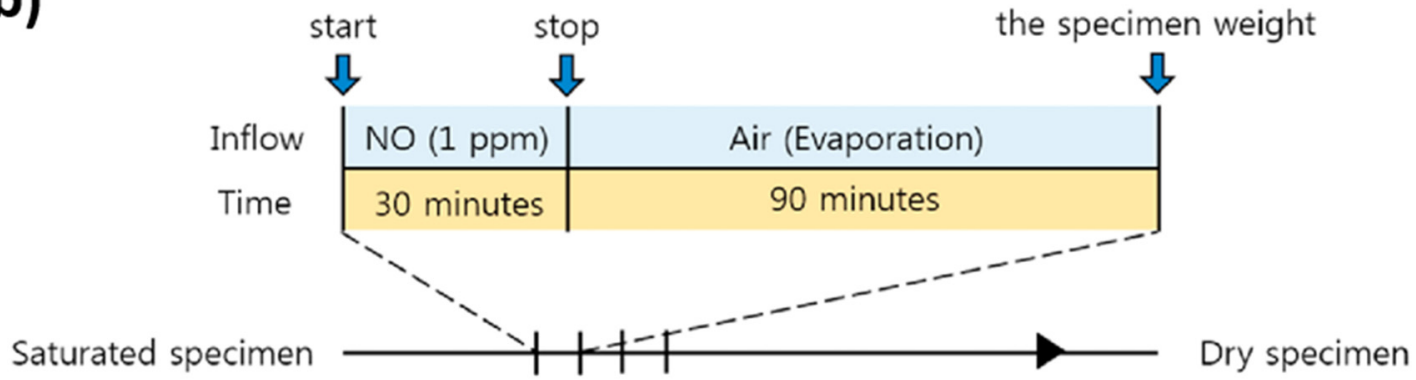

(c)
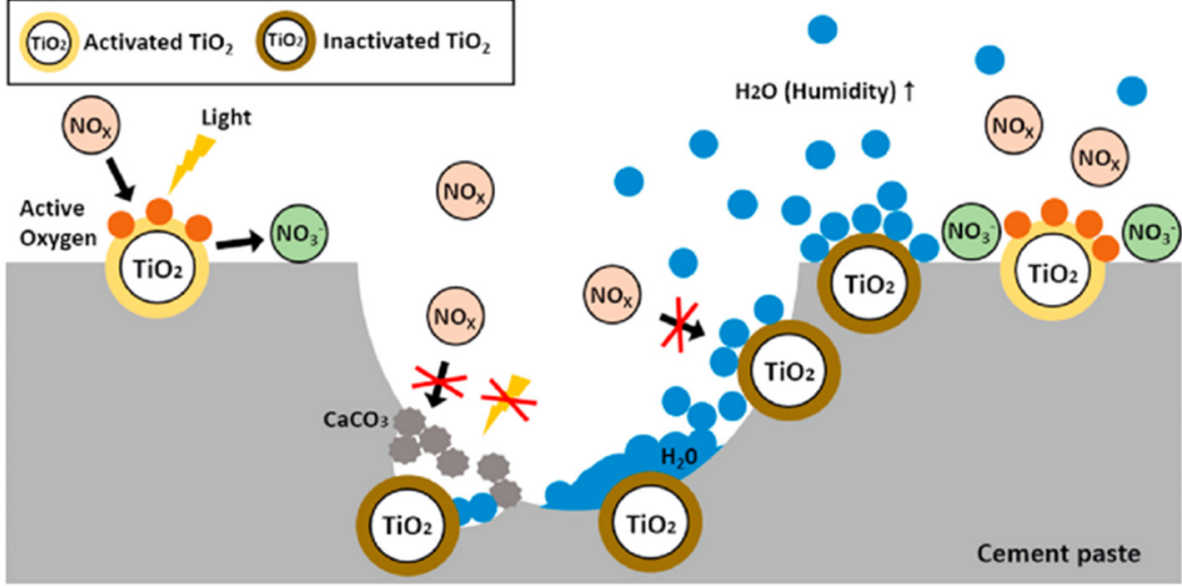

Figure 3. Experimental schemes of (a) dry and (b) wet condition test and (c) photocatalytic cement-based materials (wet conditions) [113].

The on-site determination of $\mathrm{NO}_{x}$ photocatalytic removal was performed with eco-blocks fabricated in factories [116]. In another study, specifications according to the Indonesian National Standard were done on determining the composition for the $\mathrm{TiO}_{2}$ layer coated over the pavement blocks to have required wear resistance and durability [118]. Filed experiments revealed that the hydrophilic properties of the $\mathrm{TiO}_{2}$ surface caused the hindrance of $\mathrm{NO}_{x}$ adsorption on the paving block surface because of the competition between $\mathrm{NO}_{x}$ and water vapor to reach the active sites of the catalyst. As per the results, $200 \mathrm{~g}$ of $\mathrm{TiO}_{2}$ per $1 \mathrm{~m}^{2}$ square paving blocks was required to transform ambient $\mathrm{NO}_{\mathrm{x}}$ to nitrate at an average rate of $0.0046 \mathrm{mg} / \mathrm{m}^{2} / \mathrm{min}$. Other conditions maintained in the study were: average temperature $29.89^{\circ} \mathrm{C}$, humidity $45.31 \%$, and wind speed $0.84 \mathrm{~m} / \mathrm{s}$. Functional asphalt pavements were developed by establishing bonding between pulverized $\mathrm{TiO}_{2}$-cement mortar and asphalt pavement surface through the epoxy resin. Such a design of functional asphalt showed durable $\mathrm{NO}_{\mathrm{x}}$ degradation efficiency [119]. The bonded pulverized $\mathrm{TiO}_{2}$-cement mortar to asphalt pavement 
exhibited effective NO transformation, and factors such as the anatase/rutile phase ratio and surface area of $\mathrm{TiO}_{2}$ influenced different levels of $\mathrm{NO}_{x}$ removal in the range between $14 \%$ and $67 \%$ (Figure 5).

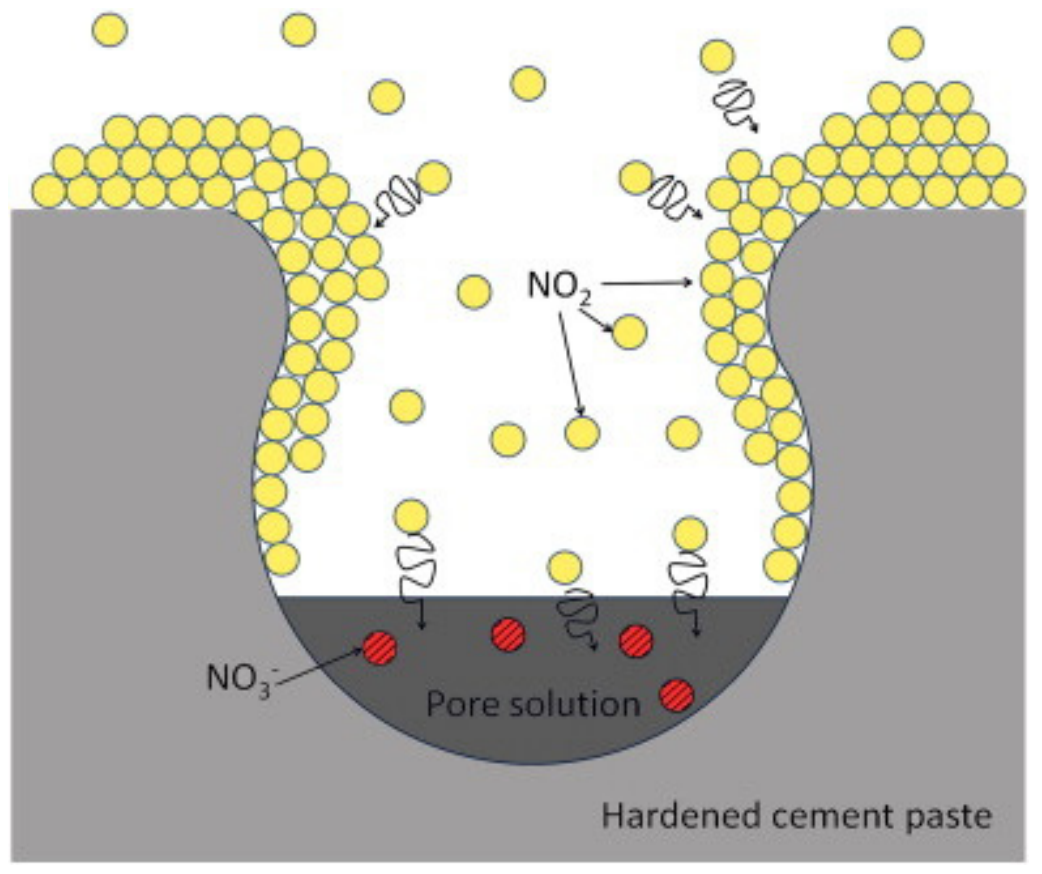

Figure 4. $\mathrm{NO}_{2}$ adsorption on hardened cement paste, as well as into the pore solution [115].



Figure 5. Average degradation efficiencies of $\mathrm{NO}$ for all studied specimens [119]. Eight $\mathrm{TiO}_{2}$ products (VU0 to VU7) with varying grain size, anatase proportions, and surface area. VU0 is the reference commercial cement mixture.

The $\mathrm{NO}_{x}$ degradation capability was evaluated in the test section built at the Institute of Highway Engineering in Aachen, Germany, to understand the applicability of the surface treatment to asphalt pavements. María Pérez-Nicolás et al. modified the mortars with two different binders (Portland cement (PC) and high alumina cement (HAC)) as well incorporating them with nano-structured photocatalytic additives (bare $\mathrm{TiO}_{2}, \mathrm{Fe}$ doped $\left(\mathrm{Fe}-\mathrm{TiO}_{2}\right)$ or vanadium doped $\mathrm{TiO}_{2}\left(\mathrm{~V}-\mathrm{TiO}_{2}\right)$ [120]. The inclusion of nano-structured additives resulted in the generation of additional nucleation sites, 
which in turn caused the acceleration of the hydration process of the cementitious binders. On the other hand, the water absorption was not significant for the photocatalyst-incorporated HAC mortars. As regards to practical application, these systems were beneficial to refine pore structures. Magdalena Janus et al. developed gypsum plates modified by $\mathrm{TiO}_{2}-\mathrm{N}, \mathrm{C}$ photocatalysts, and tested for $\mathrm{NO}_{\mathrm{x}}$ removal efficiency [121]. However, neither the photo-degradation capability towards $\mathrm{NO}_{x}$ removal nor the compressive strength were improved through the inclusion of $\mathrm{TiO}_{2}-\mathrm{N}, \mathrm{C}$ into the gypsums. The gypsum modified with a higher loading ( $20 \mathrm{wt} . \%)$ of $\mathrm{TiO}_{2} / \mathrm{N}, \mathrm{C}$, and modified at $300{ }^{\circ} \mathrm{C}$ resulted in higher $\mathrm{NO}_{\mathrm{x}}$ degradation activity. A comprehensive evaluation of the role of $\mathrm{TiO}_{2} \mathrm{NP}$ content (up to 15\%) on the mesoscale (interfacial) and macro-scale (mechanical) properties of the cementitious composites has been brought out through experimental studies [122]. A micromechanical model was proposed to understand the interrelation between meso and macro properties. The proposed model correlated the relation between tensile strain capacity and the ration of the complementary energy to crack tip toughness.

$\mathrm{TiO}_{2}$ is used in most paint formulations and finds its application in coating labs and manufacturing sites around the world. The role of $\mathrm{TiO}_{2}$ in paints is not only to provide brightness and opacity but also can be extended to $\mathrm{NO}_{x}$ control in indoor environments. In principle, photosensitized reactions on $\mathrm{TiO}_{2}$ surfaces can influence indoor air quality either beneficially or adversely. For example, $\mathrm{NO}_{x}$ may be produced through the reactions of ammonia or deposited nitric acid on the surface of the paint. On the contrary, photocatalytic $\mathrm{NO}_{x}$ removal can be beneficially derived through photocatalytic paints. The effectiveness and the outcome of using photocatalytic paints for air pollution abatement purposes is, therefore, a challenging aspect that needs to be adequately addressed to evolve new technologies to reduce indoor $\mathrm{NO}_{\mathrm{x}}$ emissions.

Truffier-Boutry et al. developed macro-sized and nano-sized $\mathrm{TiO}_{2}$-inclusive paints and studied their photocatalytic, microstructural, and morphological abilities in the process of understanding their environmental impacts [123]. Their main focus was to understand the main parameters that could control the expulsion of nano-sized particles from nano- $\mathrm{TiO}_{2}$ and to bring out safer formulations of paints having salient characteristics, such as less inclusion of nano-sized photocatalytic particles with minimal VOC-releasing possibility. The crucial conclusions derived through the study include that paints formulated with $\mathrm{TiO}_{2}$ particles having sizes smaller than $100 \mathrm{~nm}$ with rutile crystalline structures exhibited the capacity to remove air pollutants. On the other hand, xylene removal capability was observed for the paint formulation consisting of $\mathrm{TiO}_{2} \mathrm{NPs}$. Audrey Bonnefond et al. formulated photocatalytic paints containing two types of polymeric binders [124] (a pure (meth)acrylic latex (LM1), and a fluorinated/(meth)acrylic latex (CS2) with core-shell morphology) along with two types of $\mathrm{TiO}_{2}$ NPs (Degussa P25 and Johnson and Matthey (JM) sample) [125]. The substrate film-based paint was superior compared to air film because of the higher availability of interfaces at the bottom of the film for the former paint system. Riccardo Paolini et al. discussed the possible adverse effects of the solar reflectance of $\mathrm{TiO}_{2}$-containing materials. An elaborate mechanism to explain the cause for the partial reduction in and decreased crystallinity of $\mathrm{TiO}_{2}$ was proposed based on the contact with nitric acid generated by $\mathrm{NO}_{x}$ photocatalytic degradation [126]. Upon light irradiation onto the $\mathrm{TiO}_{2}$ surface in a humid environment, NOx was converted into $\mathrm{NO}$ which in turn hydrolyzed to $\mathrm{HNO}_{3}$. The adsorption of nitrates could occur on the protonated $\mathrm{TiO}_{2}$ surface arising from the acidic environment, causing an increase in oxide defect density and a decrease in crystallinity, or an increase in amorphous characteristics. The proposed mechanism (Figure 6) presents explanations for the variation of the optical behavior of $\mathrm{TiO}_{2}$ in terms of changes in morphology, surface area increase, surface defects, chemical structural changes (hydroxylation, protonation), adsorption, etc. [127]. 


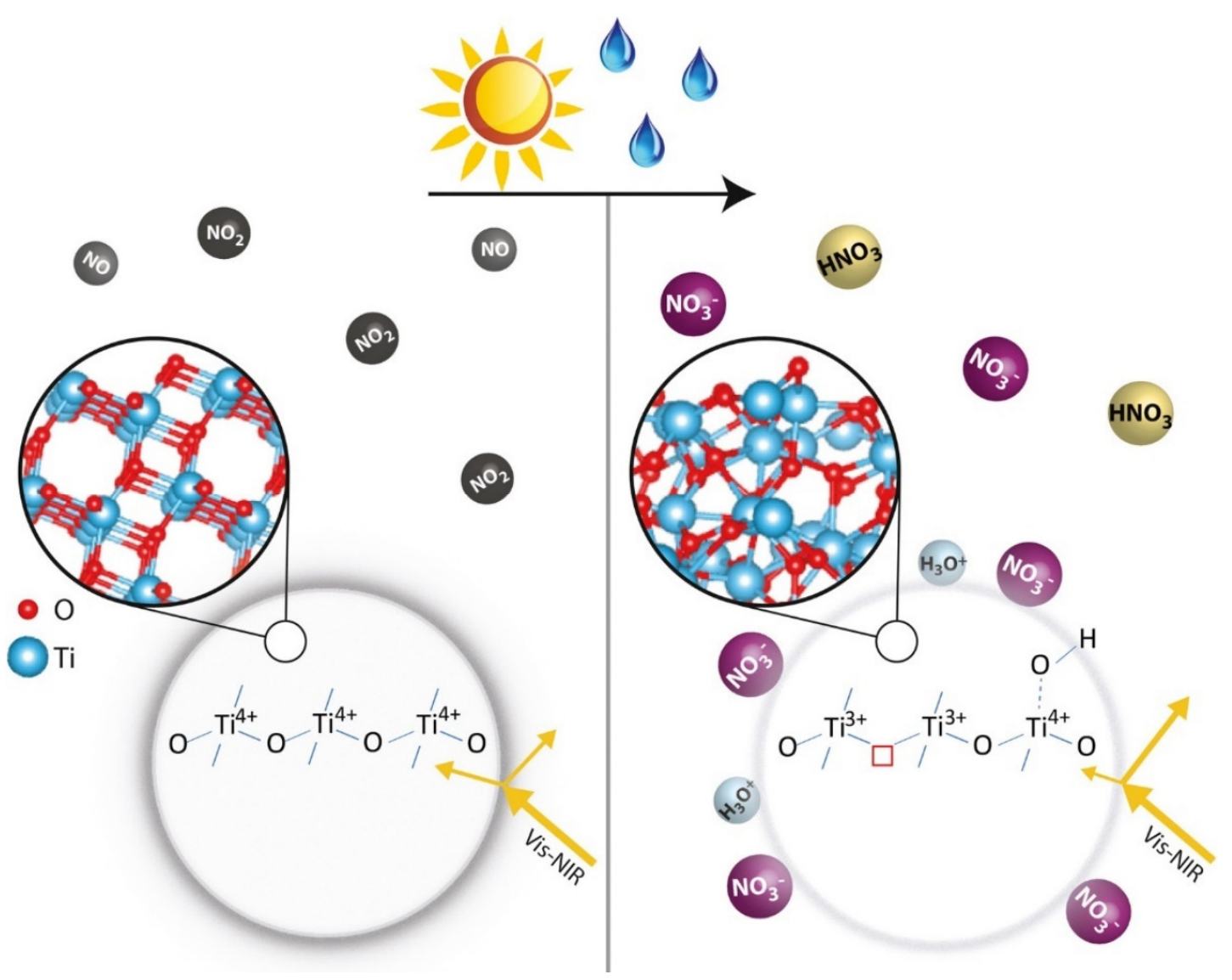

Figure 6. Scheme showing the reactions occurring at the surface of $\mathrm{TiO}_{2}$ (anatase phase) [126].

They concluded that the study could be useful to evolve strategies for developing newer self-cleaning $\mathrm{TiO}_{2}$-based construction materials with enhanced optical properties. In the process of developing functional cement-based photocatalytic products, Ming-Zhi Guo et al. formulated a modified self-compacting architectural mortars (SCAM) by applying a $\mathrm{TiO}_{2}$ containing paint as the surface coating [128]. The photocatalytic $\mathrm{NO}_{x}$ removal performance was compared between the SCAM samples prepared through brush coating of $\mathrm{TiO}_{2}$ containing paint (brush coated) and a simple non-paint formulation containing $5 \% \mathrm{TiO}_{2}$ (P25) (Figure 7) [128]. Two kinds of irradiations were used. Higher $\mathrm{NO}_{\mathrm{x}}$ removal efficiency was noticed for the PC-S7-coated SCAM sample coated with paint than the $5 \% \mathrm{TiO}_{2}$-intermixed samples under both UV-A and sunlight irradiations. The bonding between the $\mathrm{TiO}_{2}$ particles and the SCAM surface was more robust for the brush coated SCAM than the dip-coated ones. They concluded that the $\mathrm{TiO}_{2}$-coated SCAM products can be used as exterior finishing materials of buildings in urban environments.

Adrien Gandolfo et al. developed different quantities of $\mathrm{TiO}_{2} \mathrm{NP}$-inclusive photocatalytic paints and investigated the optimization of conditions for $\mathrm{NO}_{\mathrm{x}}$ remediation and $\mathrm{HONO}$ formation. The photoactivity of the developed paints was tested under a UV light in an indoor condition. The results revealed that the photocatalytic paints substantially decreased the $\mathrm{NO}_{2}$ concentration [129]. The photocatalytic paints including $0.3 \%$ to $7 \% \mathrm{TiO}_{2} \mathrm{NPs}$ were studied using a horizontal flow tube reactor. The $\mathrm{NO}_{2}$ uptake showed an increasing trend concerning $\mathrm{TiO}_{2}$ loading for the photocatalytic paint with a loading of up to $7 \% \mathrm{TiO}_{2}$ NPs. Notably, the photocatalytic paint loaded with $7 \% \mathrm{TiO}_{2}$ efficiently eliminated the majority of gas-phase $\mathrm{NO}_{2}$, converting it to $\mathrm{NO}$ and $\mathrm{HONO}$ (Figure 8). Notably, the $\mathrm{NO}$ conversion rate increased with the increase in $\mathrm{TiO}_{2} \mathrm{NP}$ content. Gas-phase HONO was predominantly formed for paint including $7 \% \mathrm{TiO}_{2} \mathrm{NPs}$. 


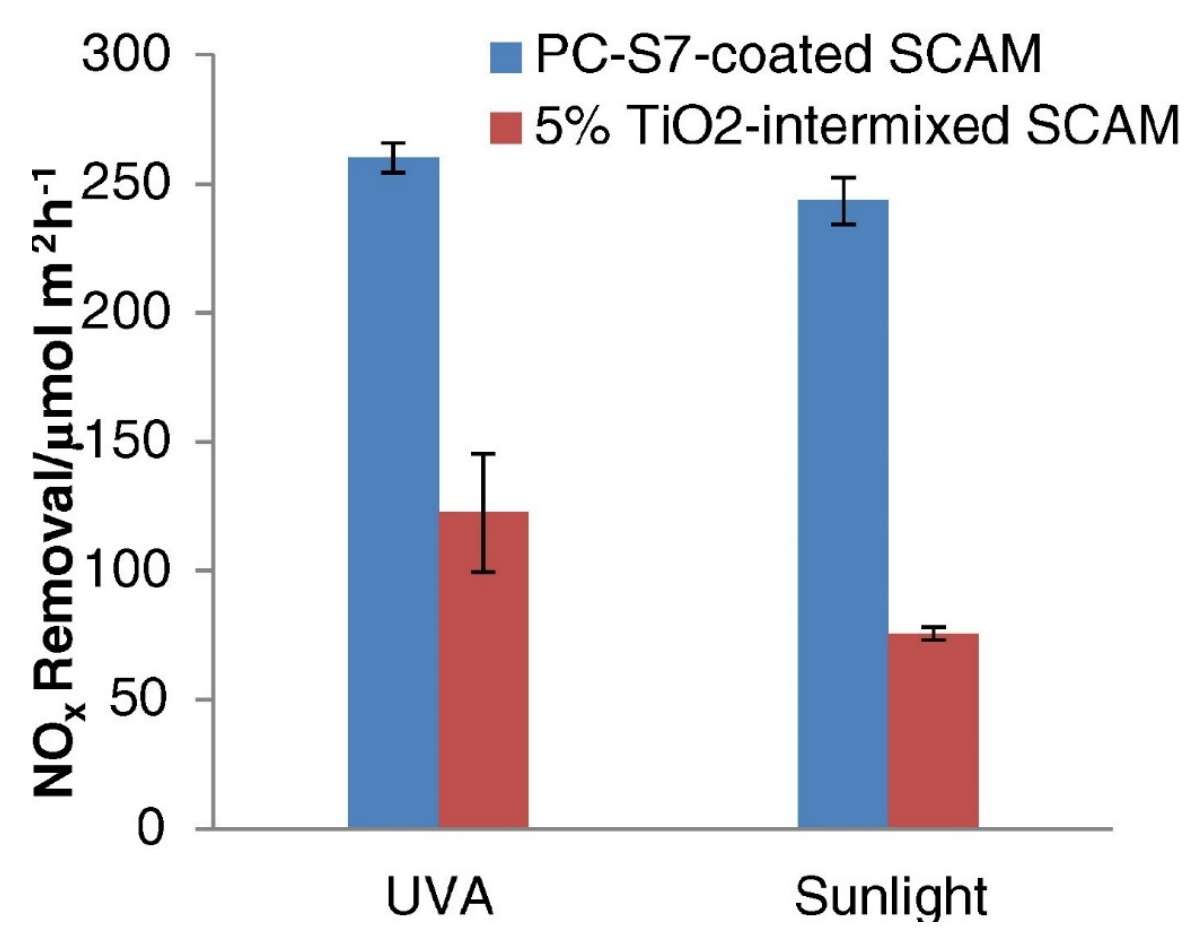

Figure 7. Photocatalytic $\mathrm{NO}_{x}$ removal on architectural mortar samples (PC-S7-coated and 5\% $\mathrm{TiO}_{2}$-intermixed) under UV-A and sunlight irradiation conditions [128].

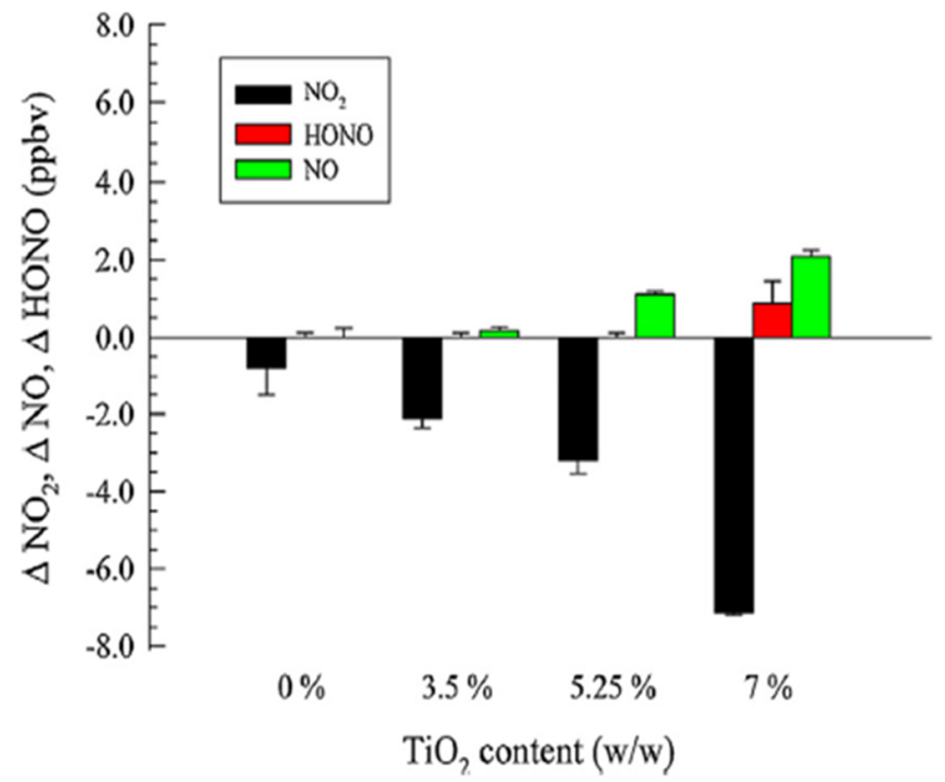

Figure 8. Formation of $\mathrm{NO}_{2}, \mathrm{NO}$, and $\mathrm{HONO}$ on photocatalytic paints with $0 \%, 3.5 \%, 5.25 \%$, and $7 \%$ of $\mathrm{TiO}_{2} \mathrm{NPs}\left(\mathrm{NO}_{2}\right.$ mixing ratio of $40 \mathrm{ppb}$ and $\mathrm{RH}$ of $\left.40 \%\right)$ [129].

A dynamic mass-balance model was proposed to predict the time-based formation of HONO in a real indoor condition. The photo-efficiency of four kinds of $\mathrm{TiO}_{2}$ coatings along with the influence of a $\mathrm{SiO}_{2}$ interlayer was investigated on $\mathrm{NO}_{x}$ photo-degradation [130]. Three types of commercial $\mathrm{TiO}_{2}$ suspensions and a home-made Titania sol-gel were used, and $\mathrm{SiO}_{2}$ layer was formed on the cement surface. The coating of the $\mathrm{SiO}_{2}$ layer in between the mortar and the commercial $\mathrm{TiO}_{2}$ coatings could not

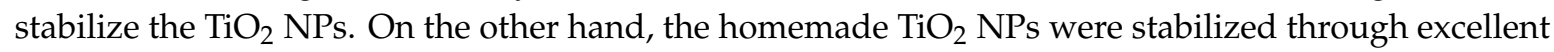
adhesion arising from the probable interactions between $\mathrm{SiO}_{2}$ and $\mathrm{TiO}_{2}$ sols. Joana Ângelo et al. evaluated outdoor $\mathrm{NO}_{x}$ abatement using photocatalytic paints incorporated with commercial $\mathrm{TiO}_{2}$ 
(Figure 9) [131]. Commercial samples of P25 from Evonik and PC500 from Cristal were utilized for developing exterior water-based paints. The standard ISO 22197-1:2007 protocol was used to evaluate the photocatalytic $\mathrm{NO}_{\mathrm{x}}$ degradation performance of these four paints. Upon performing outdoor tests, the developed paints showed a higher NO conversion rate (more than $80 \%$ ). To quote correctly, the paint comprised of PC500 and calcium carbonate exhibited the highest NO conversion of $\sim 95 \%$.

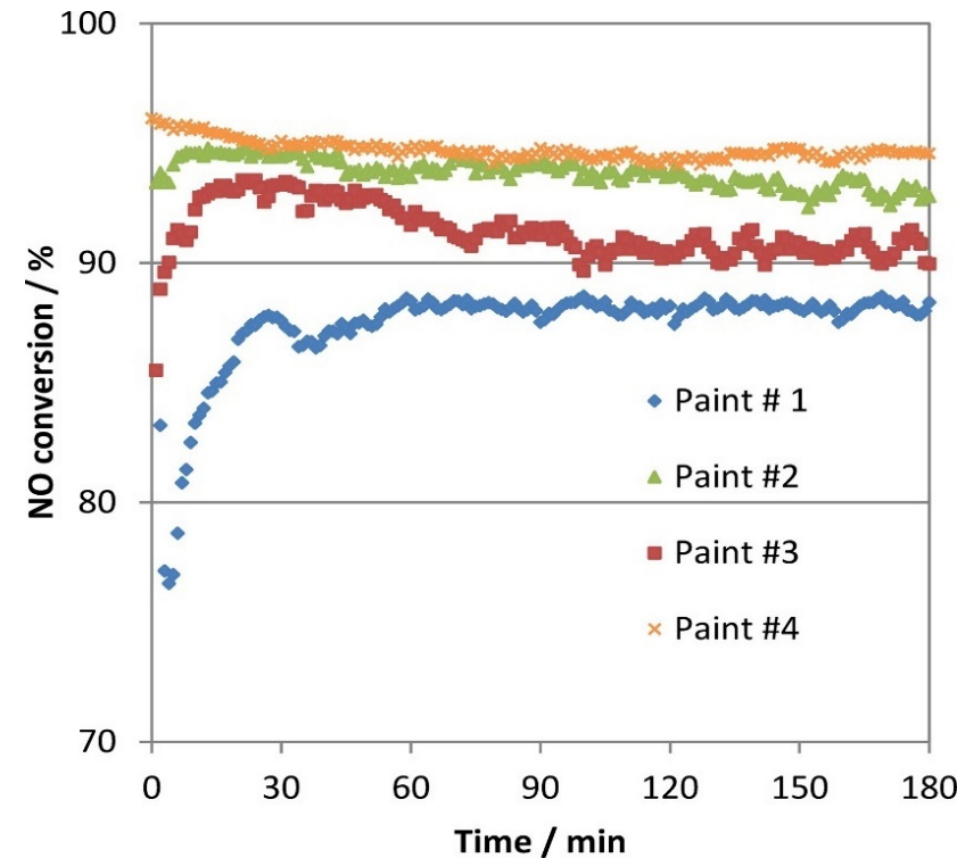

Figure 9. NO conversion for the four tested paints [131]. Paint \#1 to Paint \#4: Paints formulated with varying compositions of $\mathrm{TiO}_{2}, \mathrm{CaCO}_{3}, \mathrm{P} 25$, and $\mathrm{PC} 500$.

Luna and coworkers optimized the preparation of $\mathrm{Au}-\mathrm{TiO}_{2} / \mathrm{SiO}_{2}$ coatings and demonstrated the effectiveness of the photocatalyst compositions towards photooxidation of NO, adopting a protocol (ISO 22197-1) for monitoring NO in air purification [132]. A three-stage methodology-(i) preparation of $\mathrm{Au}$ dispersion, (ii) mixing with commercial $\mathrm{TiO}_{2}$, and (iii) integration of $\mathrm{Au}-\mathrm{TiO}_{2}$ with silica-was adopted. The observed selectivity for $\mathrm{NO}_{x}$ removal has been attributed to the enhancement of photoactivity by Au NPs as well as the possible activation of $\mathrm{O}_{2}$ and $\mathrm{NO}$ molecules through strong adsorption that could augment $\mathrm{NO}$ oxidation. Besides, the photoactivity of $\mathrm{Au}-\mathrm{TiO}_{2} / \mathrm{SiO}_{2}$ under visible light has been demonstrated for other polluting substances, such as dyes and 4-nitrophenol.

Following the success of the preparation of the $\mathrm{Au}-\mathrm{TiO}_{2} / \mathrm{SiO}_{2}$ photocatalyst, Luna and coworkers extended their research on the production of $\mathrm{Au} / \mathrm{N}-\mathrm{TiO}_{2} / \mathrm{SiO}_{2}$ photocatalysts [133]. A modified procedure was adopted that included urea as the nitrogen source. $\mathrm{NO}$ abatement tests using the $\mathrm{Au} / \mathrm{N}$ $\mathrm{TiO}_{2} / \mathrm{SiO}_{2}$ under UV light and the selectivity towards NO removal were demonstrated. Under similar $\mathrm{Au}$ loading, the $\mathrm{Au} / \mathrm{N}-\mathrm{TiO}_{2} / \mathrm{SiO}_{2}$ photocatalysts showed more photoactivity than other reference catalysts (without nitrogen doping in $\mathrm{TiO}_{2}$ ). Further to the demonstration of the photoactivity of $\mathrm{Au} / \mathrm{N}-\mathrm{TiO}_{2} / \mathrm{SiO}_{2}$ for $\mathrm{NO}$ removal, experiments ware extended on the photocatalyst coating performances by selecting three different building materials (Capri limestone, Grey Pearl granite, and HERPLAC ${ }^{\circledR}$ concrete) [134]. The coatings were formed by spraying onto one of the larger faces until its saturation. Factors such as porosity in the substrates, the $\mathrm{TiO}_{2} / \mathrm{SiO}_{2}$ ratio of the coating, the amount and size of $\mathrm{Au}$ particles, and nitrogen doping could be tuned to achieve good photoactivity.

\section{Volatile Organic Compounds}

VOCs are one of the four organic compounds classified as very quickly volatile or semi-volatile organic compounds included with particulate (especially organic) volatile organic materials [135]. 
In another version, the VOCs can be referred in terms of boiling points (between 50 and $260{ }^{\circ} \mathrm{C}$ ) for highly reactive and/or toxic organic compounds. The exposure to VOCs can cause health issues, such as respiratory diseases (eyes/nose/throat irritations), neural disorders, and sick generating syndrome (non-specific symptoms and ill-feeling health). VOCs can also be the reason for the formation of secondary pollutants, such as ozone. VOCs can cause concern both in the form of indoor and outdoor air pollutants. Indoor environments can be polluted with VOCs because of the usage of building materials, paints, fuels, cleaning materials, pesticides, materials, etc. Indoor VOC concentrations are generally 5 to 10 times highrt than outdoor environments, which, in turn, depends on the climate and other parameters [136]. Nearly fifteen years ago, an analysis performed on the existence of VOCs within a sufficiently aerated residence (without the usage of carpets and drapes) revealed the presence of the VOCs and, for easy reference, were listed by descending concentration (selected ones are given here): toluene, benzaldehyde, mono(2-ethylhexyl) phthalate, decanal, p-xylene, 1-butoxy-2-propanol, 2-butoxyethanol, undecane, $\beta$-pinene, decane, o-xylene, tetradecane, acetic acid, pentadecane, dodecane, menthol, ethylbenzene, styrene, tridecane, benzyl alcohol, camphene, methyl salicylate, naphthalene, madendrene, etc. [137]. A review published in the year 2009 details the significant changes in building materials and indoor commercial environments over the past half-century and explains the origin of some of the of VOCs in indoor environments [138]. Another review was published in the year 2016 that briefly details the general photocatalytic oxidation approaches that have been applied for the removal of VOCs and formaldehyde in indoor environments [139]. The review also provides details on potential sources for indoor expulsion of VOCs arising from building materials (Table 1).

Table 1. Possible sources of indoor pollutants of volatile organic compounds (VOCs).

\begin{tabular}{cc}
\hline VOCs & Potential Sources \\
\hline Formaldehyde & Pesticides, flooring/insulating/wood materials, coatings, paints, etc. \\
Acetaldehyde & Flooring/wood materials, etc. \\
Naphthalene & Insulating/mixed materials, etc. \\
Chloroform & Glues, pesticides, etc. \\
Ethylbenzene & Adhesive, paints, furniture, etc. \\
Dichlorobenzene & Wood/ceiling materials, etc. \\
Carbon tetrachloride & Paints, coatings, industrial cleaning agents, etc. \\
Toluene & Pesticides, flooring/insulating/wood materials, adhesives, paintings, etc. \\
Others (ketones, esters) & Perfumes, paints, adhesives, plastics, resins, disinfectants, etc. \\
\hline
\end{tabular}

The list of indoor VOCs is expected to include several more additional volatile organics in recent years because of modernization and unlimited opportunities for the use of household materials. These details and the possible concern arising from the potential exposure to VOCs in indoor air have triggered the development of new home construction techniques/materials to improve indoor air quality significantly.

\section{$\mathrm{TiO}_{2}$ Based Photocatalytic Composites for VOC Removal}

$\mathrm{TiO}_{2}$-inclusive photocatalytic materials were developed to degrade indoor VOC pollutants under UV light irradiation [140,141]. Several $\mathrm{TiO}_{2}$-based photocatalytic materials have been developed for the decomposition of VOCs [142-145]. These reviews, published in the years between 2014 and 2019 , focus the discussion on the utility of $\mathrm{TiO}_{2}$-based photocatalytic building materials towards VOC abatements. The report also summarizes the development of $\mathrm{TiO}_{2}$-based (doped, composite, nanostructured, etc.) photocatalytic materials that have been tested for VOC removal capability (Table 2) but still need to be tested through inclusion into building materials. The utilization of the reported $\mathrm{TiO}_{2}$ materials for building material development will form the platform for exploring the possibility of the development of advanced building material fabrications in the years to come. 
Table 2. Summary of $\mathrm{TiO}_{2}$ based photocatalytic composites for $\mathrm{NO}_{\mathrm{x}}$ removal.

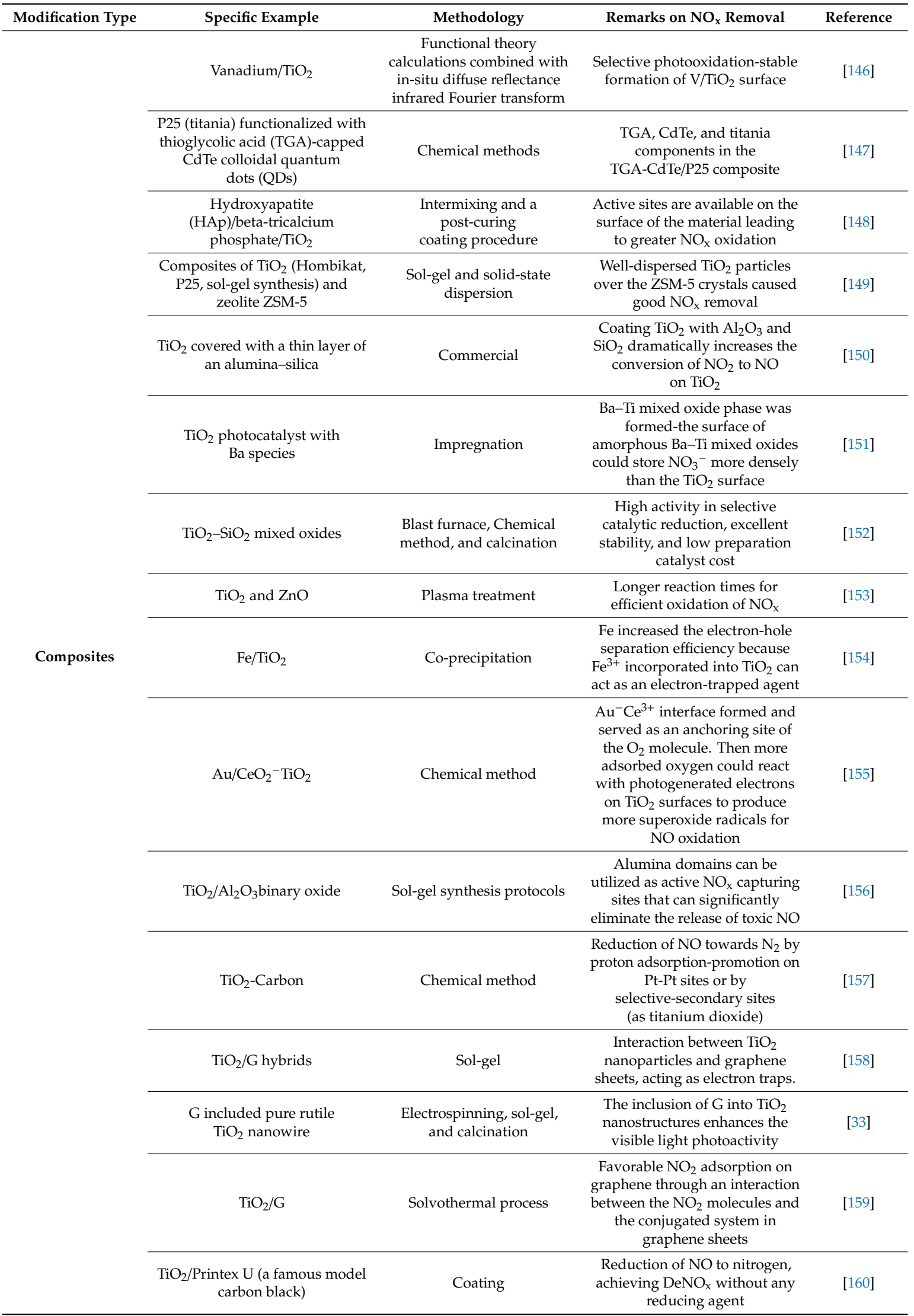


Table 2. Cont.

\begin{tabular}{|c|c|c|c|c|}
\hline Modification Type & Specific Example & Methodology & Remarks on $\mathrm{NO}_{x}$ Removal & Reference \\
\hline \multirow{8}{*}{ Doping } & $\mathrm{Ti}^{3+}$ self-doped $\mathrm{TiO}_{2} \mathrm{NPs}$ & Spray-coating & $\begin{array}{c}\text { Surface oxygen vacancies } \\
\text { caused by the diffusion of } \\
\text { photo-generated holes play } \\
{\text { significant roles- } \mathrm{Ti}^{4+} \text { is reduced }} \\
\text { to } \mathrm{Ti}^{3+}, \text { dissociating water } \\
\text { molecules and facilitating the } \\
\text { adsorption of }-\mathrm{OH} \text { species on } \\
\text { surfaces-photoinduced } \\
\text { hydrophilicity }\end{array}$ & [161] \\
\hline & Modified with $\mathrm{Ce}$, La, and Gd & $\begin{array}{l}\text { Chemical method (gel } \\
\text { precipitation) and } \\
\text { hydrothermal treatment }\end{array}$ & $\begin{array}{l}\text { The addition of rare earth } \\
\text { elements to hydrothermal } \\
\text { processing slowed the } \\
\text { anatase-to-rutile and } \\
\text { brookite-to-rutile } \\
\text { transformation-grain boundary } \\
\text { pinning effect }\end{array}$ & [162] \\
\hline & $\mathrm{TiO}_{2}$ plates doped with $\mathrm{Ba}, \mathrm{La}$ & Calcination & $\begin{array}{c}\text { Doped with } 5 \%-\mathrm{Zr}^{4+} \text { and } \\
\text { calcined at } 800{ }^{\circ} \mathrm{C} \text {, resulted in } \\
100 \% \text { degradation of } \mathrm{NO}_{\mathrm{x}} \text { as } \\
\text { compared to commercial P25. } \\
\text { The addition of } \mathrm{Zr}^{4+} \text { caused a } \\
\text { decrease in crystalline sizes of } \\
\text { both anatase and rutile forms } \\
\text { causing an increase in } \\
\text { surface area }\end{array}$ & [163] \\
\hline & Ni doping & Thermal treatment & $\begin{array}{l}6 \% \text { weight Nickel doped KA100 } \\
\text { and annealed at } 1000{ }^{\circ} \mathrm{C} \text { showed } \\
\text { excellent } \mathrm{NO}_{\mathrm{x}} \text { removal. } \\
\text { Transformation into } 100 \% \text { rutile } \\
\text { phase and size effects played } \\
\text { roles in photoactivities. }\end{array}$ & [164] \\
\hline & $\mathrm{Cu}, \mathrm{Zn}$, and $\mathrm{Cu}-\mathrm{Zn}$ & Thermal treatment & $\begin{array}{c}0.25 \mathrm{Cu} / 0.75 \mathrm{Zn}-\mathrm{Ti} 450(\mathrm{Cu}: \mathrm{Zn} \\
\text { molar ratio equal to } 1: 3) \text { was the } \\
\text { best performing specimen in } \\
\text { degrading } \mathrm{NO}_{x}\end{array}$ & [165] \\
\hline & $\begin{array}{l}\text { Carbon-doped titanium dioxide } \\
\text { and nano-silica }\end{array}$ & $\begin{array}{l}\text { Coating and UV-pre } \\
\text { treatment }\end{array}$ & $\begin{array}{l}\text { Highest } \mathrm{NO} \text { degradation is } \\
\text { achieved by the two-layered } \\
\text { coatings comprised of } \\
\text { carbon-doped } \mathrm{TiO}_{2} \text { and silica }\end{array}$ & [166] \\
\hline & Nitrogen modified $\mathrm{TiO}_{2}$ & $\begin{array}{l}\text { Sol-gel green synthetic } \\
\text { method }\end{array}$ & $\begin{array}{c}\text { Heated at } 450{ }^{\circ} \mathrm{C} \text { possessed } \\
\text { excellent photocatalytic activity } \\
\text { under visible white-light (indoor } \\
\text { artificial lighting)-double PCA } \\
\text { than } \mathrm{P}_{2} 5 \mathrm{TiO}_{2} \mathrm{NPs} \text {. }\end{array}$ & [167] \\
\hline & $\begin{array}{l}\text { Barium-modified } \\
\text { titanium dioxide }\end{array}$ & Impregnation method & $\begin{array}{c}\text { BaO species, which was } \\
\text { generated from the } \\
\text { decomposition of } \mathrm{Ba}\left(\mathrm{NO}_{3}\right)_{2} \\
\text { works as a } \mathrm{NO}_{x} \text { storage material }\end{array}$ & [168] \\
\hline \multirow{5}{*}{$\begin{array}{l}\text { Nanostructuring } \\
\text { and physical } \\
\text { modifications }\end{array}$} & $\begin{array}{l}\text { The electronic crystallographic } \\
\text { structural relationship for } \\
\mathrm{Ti}_{0.909} \mathrm{~W}_{0.091} \mathrm{O}_{2} \mathrm{~N}_{\mathrm{x}}\end{array}$ & Mixing and calcination & $\begin{array}{l}\text { Oxygen vacancy acts as an } \\
\text { electron trapping center for } \\
\text { conduction-band electrons and } \\
\text { reduction of NO }\end{array}$ & [169] \\
\hline & $\begin{array}{l}\mathrm{TiO}_{2} \text { to detect secondary aerosol } \\
\text { pollutant formation }\end{array}$ & Seed via atomization & $\begin{array}{l}\text { Reactive carbonyl compounds } \\
\text { caused by the photo- } \\
\text { degradation role of } \mathrm{TiO}_{2} \text { lead to } \\
\text { the suppression of } \mathrm{C} \text { formation }\end{array}$ & [170] \\
\hline & $\begin{array}{l}\text { Titanium dioxide nanosheets } \\
\text { and anatase titanium dioxide } \\
\text { nanospindles with highly } \\
\text { exposed (001) facets }\end{array}$ & $\begin{array}{l}\text { Hydrothermal and } \\
\text { faceted engineering }\end{array}$ & $\begin{array}{l}\text { Preferential exposure of (001) } \\
\text { facets of } \mathrm{TiO}_{2} \text { had a positive } \\
\text { effect on increasing the specific } \\
\text { surface area of the catalysts }\end{array}$ & {$[171]$} \\
\hline & Size controlled nanoparticles & Controlled annealing & $\begin{array}{l}\text { Mortar mixtures with only } \\
1 \text { wt. } \% \mathrm{TiO}_{2} \text { resulted in NOx } \\
\text { degradation rates close to } 80 \%\end{array}$ & [172] \\
\hline & $\begin{array}{l}\text { Crystalline mixed-phase } \\
\text { (Anatase/Rutile) mesoporous }\end{array}$ & $\begin{array}{l}\text { Calcination at temperatures } \\
\left(600-800^{\circ} \mathrm{C}, 1^{\circ} \mathrm{C} / \mathrm{min}\right) \\
\text { followed by a second } \\
\text { heat treatment }\end{array}$ & $\begin{array}{l}\text { A synergetic effect between } \\
\text { anatase and rutile }\end{array}$ & [173] \\
\hline
\end{tabular}


Fumihide et al. compared the efficiencies of the photocatalytic decomposition of VOCs between two arrangements, namely, parallel and circular, for the removal studies (Figure 10). The parallel arrangement was designed by keeping the UV lamps parallel to flat $\mathrm{TiO}_{2}-\mathrm{PET}$ sheets. In the case of a circular arrangement, a UV lamp was held in a glass tube, and the cylindrical $\mathrm{TiO}_{2}$-PET sheet was arranged close to the surface of the lamp [174]. The photo decompositions of acetone, isopropanol (IPA), and toluene were studied. The circular arrangement outperformed the parallel one and was preferred for optimal VOC decomposition. A general conclusion was drawn based on the results. The complete decomposition of VOCs, including their intermediates, could be achieved with a UV intensity above a certain threshold and the choice was also based on the types of VOCs present. Julien Morin et al. used a horizontal flow tube reactor to study VOC emissions from paints that included mineral silicate binders, acrylic binders, and acrylic/siloxane binders with/without incorporated $\mathrm{TiO}_{2}$ NPs [175]. In the majority of the experiments, it was found that the mineral binder-inclusive paints emitted fewer VOCs as compared to the acrylic binder-inclusive ones. The surface-emission fluxes of the VOCs, such as formaldehyde, acetaldehyde, benzene, aromatics, acids, and carbonyls, were studied under UV irradiation for the photocatalytic paints. The results of mineral silicate and acrylic/siloxane binders were compared with an acrylic binder to infer the impacts and effects of the paint composition. The surface-emission fluxes of carbonyl compounds were presented and discussed (Figure 11). They concluded that the binder inclusion did not significantly enhance the properties of the photocatalytic paints concerning VOC emissions. Nejc Rozman et al. prepared rare earth element (such as $\mathrm{La}, \mathrm{Gd}$, and $\mathrm{Ce}$ ) modified $\mathrm{TiO}_{2}$ and assessed the photocatalytic degradation of a few VOCs [162].

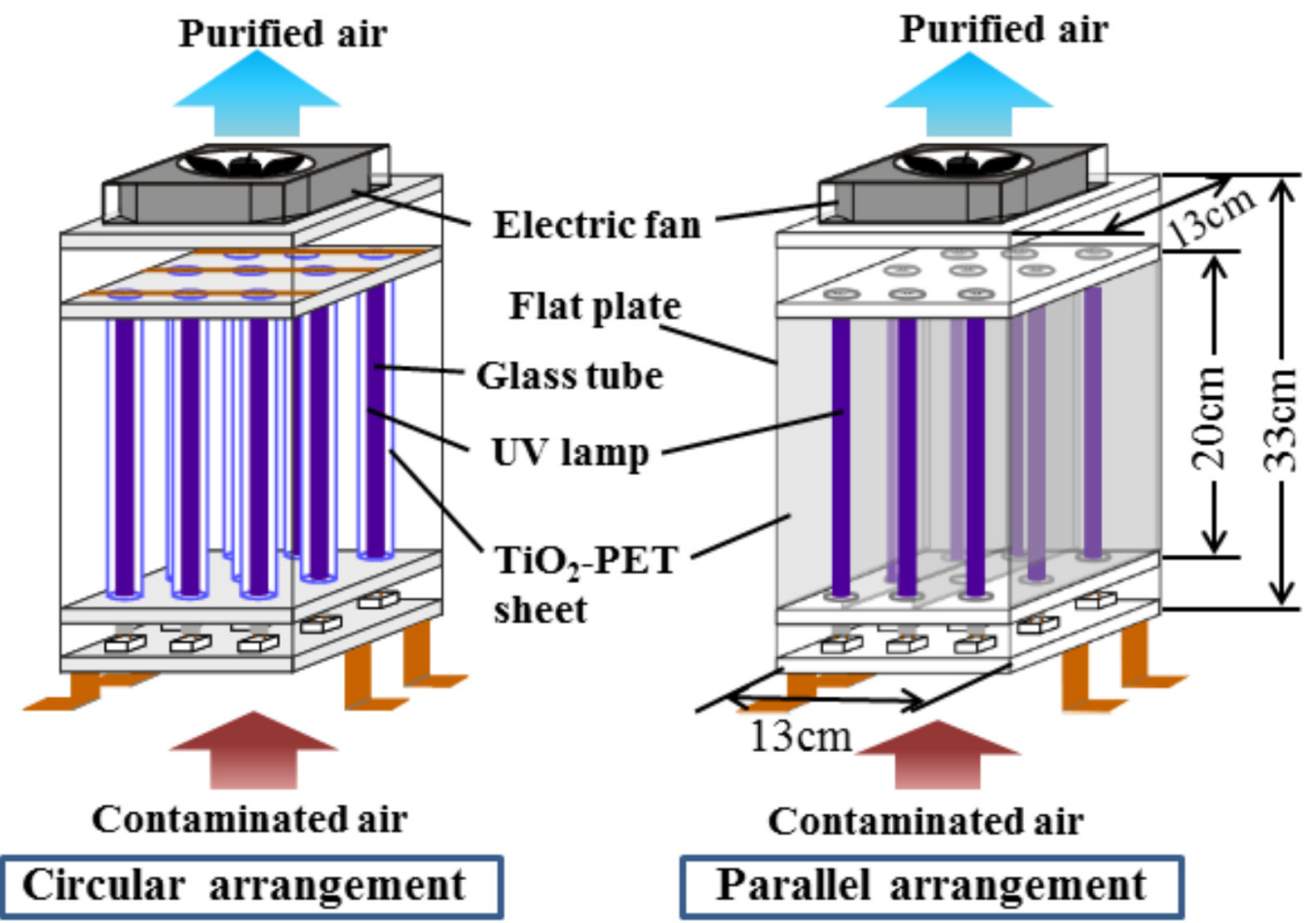

Figure 10. Arrangement of UV lamps and $\mathrm{TiO}_{2}-\mathrm{PET}$ sheets (surface area of the $\mathrm{TiO}_{2}-\mathrm{PET}$ sheet) [174]. 


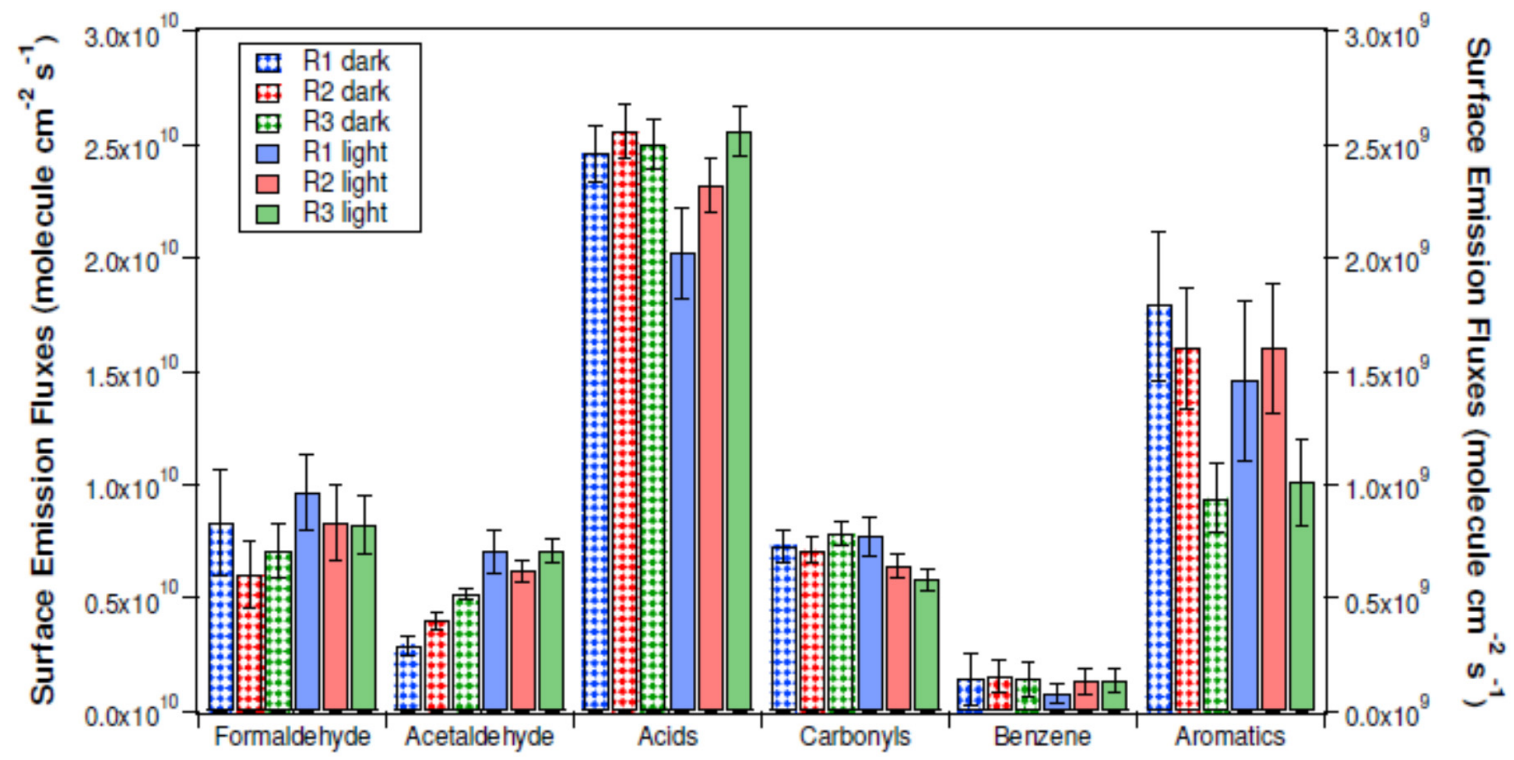

Figure 11. Surface emission fluxes (molecule $\mathrm{cm}^{-2} \mathrm{~s}^{-1}$ ) obtained for selected VOCs (formaldehyde, acetaldehyde, acids, carbonyls, aromatics, and benzene) under "dark" conditions (lozenge) and in the presence of a UV light (solid) [175].

A reactor comprising of a gas pump and pipes was set up to understand the degradation kinetics using Fourier-transform infrared spectroscopy. The research paper reported comparative data on the photocatalytic isopropanol oxidation between simulated solar light and UV irradiation as well as pristine $\mathrm{TiO}_{2}$ and rare earth element-doped $\mathrm{TiO}_{2}$. Birte Mull et al. developed pure $\mathrm{TiO}_{2}$ or $\mathrm{TiO}_{2}$ modified with graphene oxide (GO)-inclusive photocatalysts and investigated the photocatalytic degradation of a few of VOCs (butyl acetate, toluene, and limonene) under UV LED (light emitting diodes)/blue LED light irradiation conditions [176]. Based on irradiation experiments, they inferred that the modified $\mathrm{TiO}_{2}$ samples with trace amounts of GO $(0.75-5 \%)$ showed better photocatalytic performance under blue light. However, photocatalysts loaded with a higher value of GO (10\% or higher) caused adverse photoactivity both under UV and blue light irradiation conditions. Zahra Shayegan et al. investigated the three levels (bench-scale, pilot, and full) of scaling effects on the removal efficiency of toluene and isobutanol removal efficiency as well as the generated by-product by evaluating the UV-irradiated photocatalytic oxidation performance using a commercial $\mathrm{TiO}_{2}$ photocatalyst (Figure 12) [177]. Based on the factor $\theta$ (mg VOCs/g photocatalyst media), a comparison between the three scales (full, pilot, and bench) was made on the gravimetric (per mass) pollutant removal efficiency for toluene and isobutanol in terms of the flow rate of pollutants and the weight of the photocatalyst. Conditions such as residence time, flow rate, and humidity were optimized to derive extrapolated information for real indoor application. Full-scale studies showed that toluene could not be effectively removed in UV-assisted PCO due to the higher velocity of flowing gas and lower light distribution. However, studies performed with $100 \mathrm{ppb}$ and $1000 \mathrm{ppb}$ concentrations of isobutanol showed a $24.1 \%$ and $8.6 \%$ removal efficiency, respectively (Figure 12). 
Full-scale

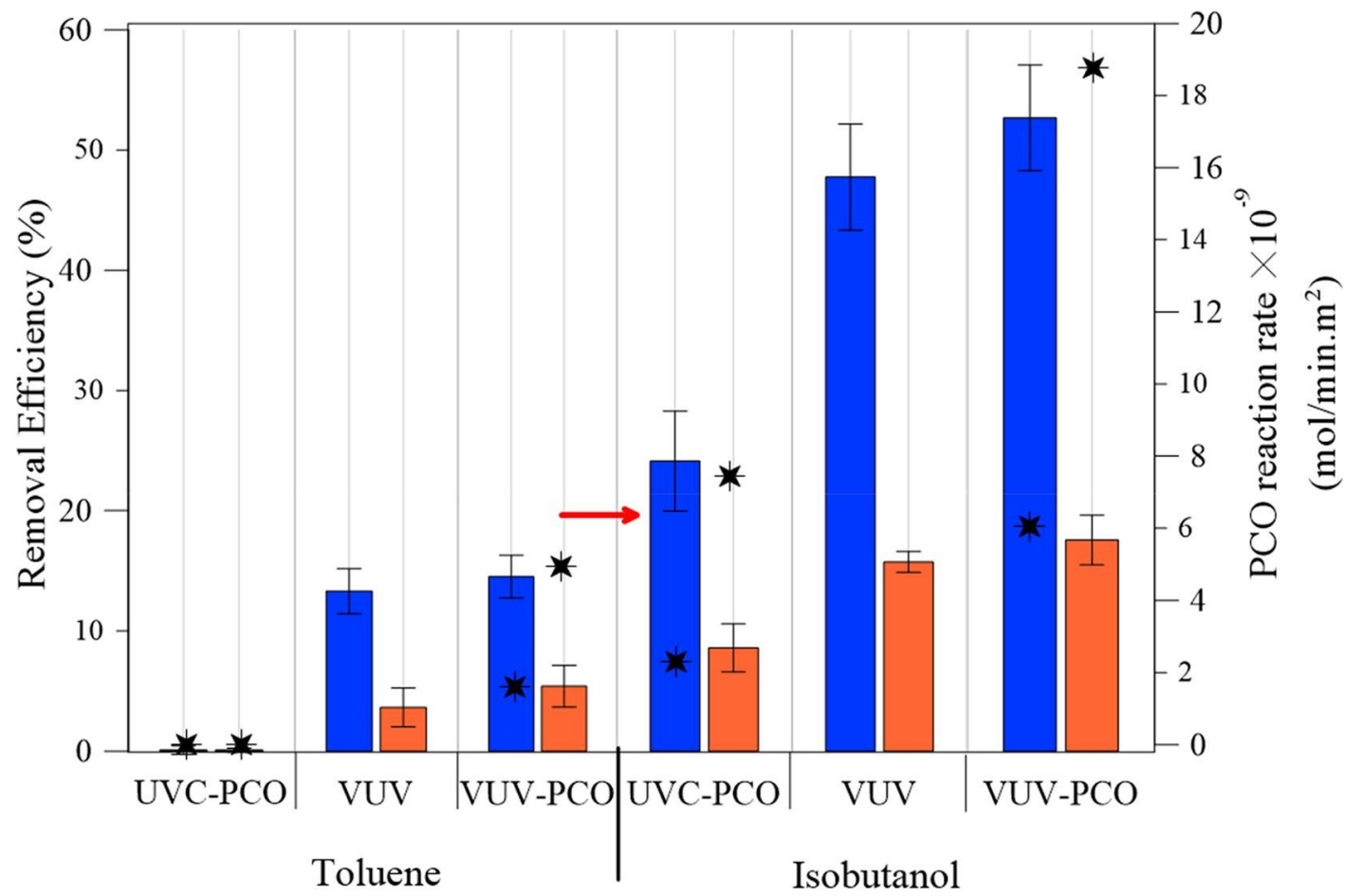

\section{$100 \mathrm{ppb} \quad 1000 \mathrm{ppb} \quad$ Reaction rate $*$}

Figure 12. Removal efficiency of toluene and isobutanol and $\mathrm{PCO}$ reaction rate for different systems (UVC-PCO, VUV photolysis, and VUV-PCO) (V = $1.25 \mathrm{~m} / \mathrm{s}$ ) [177]. PCO: photocatalytic oxidation; UVC: ultravacuum, VUV: vacuum ultraviolet.

Alireza Haghighat Mamaghani et al. presented a comprehensive overview of commercial $\mathrm{TiO}_{2}$ photocatalyst-based VOC removal in air [14]. Enhanced photocatalytic activity could be achieved through fine-tuning physical properties (crystallinity, crystal size, anatase and rutile phase compositions, and porosity) and surface properties (amount of surface hydroxyl groups, surface area, and surface density) of the $\mathrm{TiO}_{2}$. The role of support materials, such as activated carbon, on the adsorption and removal efficiency of VOC was detailed. Ming-Jun Tian et al. prepared a porous photocatalyst composite comprised of ultralong $\mathrm{TiO}_{2}$ nanofibers (TiNF) distributed in activated carbon fiber (ACF) (TiNF/ACF) porous composites by the depositing TiNFs within ACF felts, the support matrix [178]. They observed improved photocatalytic performance for toluene removal because of synergetic effects arising from the interaction between the TiNFs and ACFs (Figure 13). A mechanism for efficient photocatalytic activity was suggested. ACFs play multiple roles, such as hindering the recombination of electron-hole pairs, enhancing the light adsorption ability by reducing the $\mathrm{TiO}_{2}$ bandgap energy (Eg) to $2.99 \mathrm{eV}$, and increasing the quantum efficiency of $\mathrm{TiO}_{2}$. Typically, a high surface area and macroporous structure of composite photocatalysts could result in higher adsorption efficiencies $(98.9 \%)$ for a toluene concentration of $<4600 \mathrm{ppm}$. Zhuowei Cheng et al. used a combined sol-gel hydrothermal methodology for the preparation of $\mathrm{La} / \mathrm{N}-\mathrm{TiO}_{2}$ nanotubes [179] and evaluated photocatalytic activity towards chlorobenzene. A greater surface area and smaller particle sizes were produced with the co-doped $\mathrm{TiO}_{2}$ nanotubes. The relative humidity of the system played a role in the conversion of chlorobenzene. A probable mechanism involving a water molecule for the photocatalytic chlorobenzene conversion is presented. 


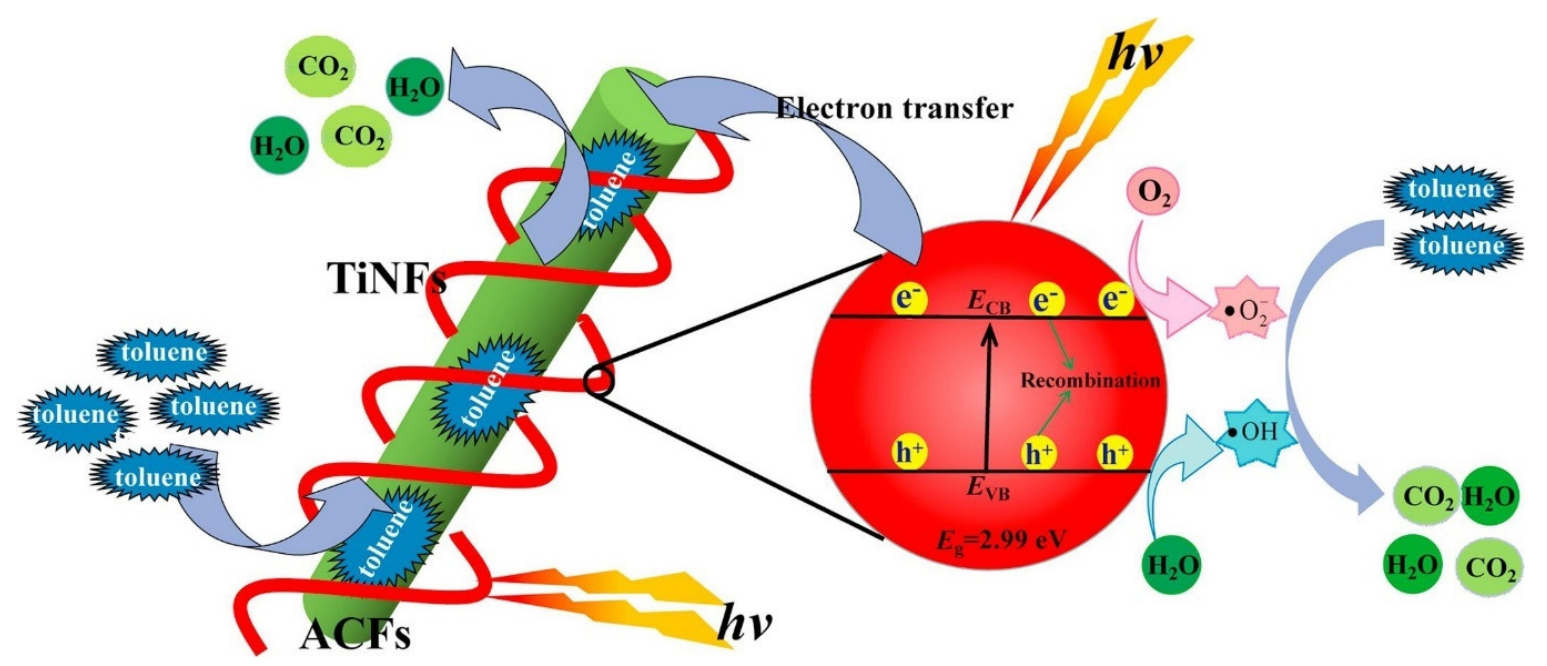

Figure 13. Scheme depicting the adsorption and photo-degradation synergetic model of $\mathrm{TiO}_{2}$ nanofibers/Activated carbon fiber (TiNF/ACF) porous composites towards toluene removal [178].

D. Truffier-Boutry et al. formulated paints based on micro-sized and nano-sized $\mathrm{TiO}_{2}$ particles and studied their VOC emission/removal efficiency [123]. However, the results informed that few of the organic compounds, with a predominance of the harmful pollutant formaldehyde, and other compounds such as methanol, acetaldehyde, were removed upon light irradiation. D. Enea et al. evaluated the photocatalytic activity of three photocatalytic paints prepared with different $\mathrm{TiO}_{2}$ samples under UV as well as solar light irradiation, considering the degradation of 2-propanol as the probe molecule [180]. The results informed that the photocatalytic activity of the paints was influenced by the changes in the surface hydrophilicity and the aging process. Natan Blommaerts et al. evaluated the gas-phase degradation of acetaldehyde by photocatalytic paints coated over the entire interior parts of the spiral tubes and assessed the gas-phase photocatalytic degradation of acetaldehyde [181]. Superior photocatalytic performances were noticed for both the single and double cylinder coated cylinders over a vast set of experimental conditions. They derived reasons for the superior VOC degradation efficiency of the spiral reactors over the conventional photocatalytic reactors. The possible reasons could be because of (1) the probability of uniform illumination over the entire reactor length, (2) optimized light transmission, and (3) effective contact establishment between the gaseous reagents and the irradiated surface over the whole tube length. A comparative result informed that a spiral reactor could show a $100 \%$ acetaldehyde degradation efficiency for a low residence time of $60 \mathrm{~s}$. On the other hand, $100 \%$ acetaldehyde degradation could be achieved from the annular reactor even at $1000 \mathrm{~s}$ residence time.

Wenda Zhu et al. developed photocatalytic coatings for barn walls and ceilings for mitigating indoor odors based on a few of the new $\mathrm{TiO}_{2}$-samples, PureTi Clean, Evonik, and P25 [182]. They utilized these paints to understand their effects in decreasing odorous VOC emissions through stimulated evaluating, with stimulated conditions having few organic compounds like diethyl sulphide, dimethyl disulfide, dimethyl trisulfide, butyric acid, $\mathrm{p}$-cresol, and guaiacol. The pure Ti-based coating, with a loading of $10 \mu \mathrm{g} / \mathrm{cm}^{2}$ photocatalyst, showed the highest removal rate for a few of the selected odor compounds.

C. Toro et al. studied the uptake coefficients of a few of the selected VOCs onto commercial $\mathrm{TiO}_{2}$ coating in a continuously stirring reactor tank [183]. The molar yield and the composition of the aldehyde mixture were monitored during the removal of each VOC. The highest level of acetaldehyde production was evident from toluene photooxidation, while the lowest was from mesitylene. The $\mathrm{Ag}^{+}$ doped $\mathrm{TiO}_{2}$ was synthesized and successfully incorporated into a natural hydraulic lime mortar [184]. The gas-phase VOC photo-degradation capability of the modified lime mortar was assessed under the irradiation of artificial visible light. The $1 \mathrm{wt} . \%$ and $5 \mathrm{wt} . \% \mathrm{Ag}^{+}$doped $\mathrm{TiO}_{2}$ incorporated mortar 
samples produced $1.8 \mathrm{ppm} / \mathrm{h}$ and $2.9 \mathrm{ppm} / \mathrm{h}$ of acetone, respectively. A non-linear relationship between photocatalytic activity and wt. $\% \mathrm{Ag}^{+} \mathrm{TiO}_{2}$ was noticed. The modified mortar exhibited VOC degradation under artificial visible light of the kind used for indoor illumination, without any UV component. The photocatalytic activity towards VOCs was lower than that of $\mathrm{NO}_{\mathrm{x}}$ abatement. A mechanism for the visible light photoactivity was presented. The Ag NPs clustered nearer to $\mathrm{TiO}_{2}$ NPs could harvest visible light and trigger the PCO of VOC gases, specifically causing the degradation of isopropanol into acetone. Magdalena Janus et al. prepared several concrete- $\mathrm{TiO}_{2}$ or C- $\mathrm{TiO}_{2}$ composites using $\mathrm{N}-\mathrm{TiO}_{2}$ or $\mathrm{C}-\mathrm{TiO}_{2}$ and concrete as raw materials [185]. The modification of $\mathrm{TiO}_{2}$ with $\mathrm{N}$ or $\mathrm{C}$ enhanced the photocatalytic oxidation process for gaseous pollutants.

\section{Self-Cleaning}

Ever since the concept of "self-cleaning" was initially unveiled based on the superhydrophobic property of lotus leaves, the importance of the self-cleaning principle has been realized towards developing many innovative superhydrophobic materials by researchers from surface chemistry to material science utilizing them for practical applications. The three processes, namely wetting, dewetting, and adhesion of the surface, are, in turn, related to self-cleaning and can be understood using contact angle (CA) measurements. CA refers to the angle between the liquid-solid interface and the liquid-vapor interface. The assessment of CA measurements can be performed in terms of advancing angle $\theta_{\mathrm{A}}$, static contact angle $\theta$, receding angle $\theta_{R}$, and sliding angle $\alpha$ [186].

Based on the CA, the nature of a surface is defined as hydrophilic when $\theta_{R}$ is $<90^{\circ}$ and hydrophobic when $\theta_{\mathrm{R}}$ is $>90^{\circ}$. Additionally, a superhydrophobic surface with $\theta_{\mathrm{A}}$ is $\geq 145^{\circ}$ does not have an affinity for water. Superhydrophobic properties arise for non-smooth/rough surfaces having $\geq 145^{\circ}$ and $\alpha$ as $<5-10^{\circ}$ with possible hysteresis in the CA. The superhydrophobic property of lotus correlates with $\theta>150^{\circ}$ and a small $\alpha<2^{\circ}$. Interestingly, other unusual characteristics, such as superhydrophobic super-wetting, are related to surfaces having a strong affinity for water and liquid surfaces. The term "superhydrophilicity" was first introduced by Fujishima et al. [187] and subsequently, a flurry of research activities were triggered on superhydrophobic properties of surfaces and their associated applications [188]. Dreich and Chibowski redefined superhydrophobic materials as rough and porous materials having a surface roughness (Wenzel) factor larger than 1 . On superhydrophilic surfaces, water (liquid) spreading occurs entirely [189]. In general, the removal or cleaning of surface-coated/adhered contaminants from the surface is dependent on surface properties, such as wettability and surface energy, which in turn decide the mobility of water on the surface. The wettability of the surface is dependent on the morphology, free energy, and chemical properties of the surface, along with the viscosity and other properties of the spreading liquid [190]. It must be noted that effective surface cleaning by water for both superhydrophobic and super hydrophilic surfaces can be explained by various mechanisms [191-193]. Different models are available to explain the surface-wetting process over multiple surfaces [194-198].

In 1997, the self-cleaning and antifogging characteristics of the $\mathrm{TiO}_{2}$ surface under UV light irradiation were first demonstrated by Fujishima et al., and the results revealed that superamphiphilic surfaces were produced through photo-initiated processes [194]. The irradiation of anatase $\mathrm{TiO}_{2}$ coated on a glass substrate generated photocatalysis and photo-induced super hydrophilicity, simultaneously, through intrinsically different methods. Typically, the surface of anatase $\mathrm{TiO}_{2}$ coated on a glass substrate, which was having a water-contact angle of $72^{\circ} \pm 1^{\circ}$ before UV irradiation, changed to a surface that spreads water after UV irradiation. This breakthrough research initiated a new era on $\mathrm{TiO}_{2}$-based self-cleaning materials. Extensive research activities on $\mathrm{TiO}_{2}$-based self-cleaning materials opened up application avenues for these materials in different disciplines, such as environment, energy, and industries, and generated a scope for new business/markets.

In recent years, $\mathrm{TiO}_{2}$-based photocatalytic materials have been effectively utilized for mitigating environmental pollution and damage control on a global scale, leading to the development of commercial products [191,199-203]. Further, the development of $\mathrm{TiO}_{2}$-based advanced materials 
for viable environmental cleanup has attracted a great deal of attention. Now, a variety of $\mathrm{TiO}_{2}$-based materials have been commercialized, arising from their unique photo-induced properties. $\mathrm{TiO}_{2}$-based self-cleaning materials can destroy bacteria that adhere to its surface under UV or visible irradiation. The superhydrophilicity property of self-cleaning $\mathrm{TiO}_{2}$-based materials favors the complete spreading of water droplets at a faster speed on their surface which contributes to the removal of contaminants/pollutants adhered on the surface. With regards to construction materials, coating materials, such as glass, tiles, fabrics, cement, and paints, were developed utilizing the photo-induced hydrophilic conversion of $\mathrm{TiO}_{2}$ surfaces. In the past few years, self-cleaning materials have attracted much attention, and a series of $\mathrm{TiO}_{2}$-based self-cleaning coatings have been fabricated on a variety of substrates [204,205].

Studies informed that the augmented self-cleaning property of $\mathrm{TiO}_{2}$ could be achieved when the surface was exposed to a stream of water flow. Therefore, self-cleaning can be effectively implemented with $\mathrm{TiO}_{2}$ coatings on the exterior of buildings because the exterior walls are expected to be exposed to abundant sunlight and natural rainfall. A variety of $\mathrm{TiO}_{2}$-based self-cleaning construction materials, including cement, tiles, plastics, glass, aluminum sliding, etc., have been commercialized. On the practical side, glass surfaces coated with $\mathrm{TiO}_{2} \mathrm{NPs}$ and having self-cleaning properties can be seen at the National Opera Hall, China [191]. At the Dives in Misericordia Church, Rome, Italy, self-cleaning white cement consisting of $\mathrm{TiO}_{2} \mathrm{NPs}$ has been utilized as the construction material [84]. In Japan, a more significant number of buildings have been constructed with self-cleaning tiles including $\mathrm{TiO}_{2}$. The PanaHome Company from Japan popularizes "eco-life" type houses constructed with self-cleaning windows, solar cell-inclusive roof-tops, and tiles [206].

Strategies were evolved to enhance the efficiency of the photocatalytic and self-cleaning properties of $\mathrm{TiO}_{2}$ through doping with metals/non-metals, generation heterojunctions between $\mathrm{TiO}_{2}$ and other low bandgap semiconductors, and the inclusion of graphene. The enhancement in the photoactivity of $\mathrm{TiO}_{2}$ was explained in terms of bandgap tuning, creation of localized energy levels within the bandgap, and generation of intrinsic defect sites. Several reviews have been published on the self-cleaning action of $\mathrm{TiO}_{2}$ over the past years which mainly discuss the photocatalytic activity of $\mathrm{TiO}_{2}[39,205,207]$. In recent years (2015-2019), researchers developed self-cleaning building materials based on cement, concrete, or asphalt concrete, with the inclusion of surface-modified, functional component-incorporated, or doped $\mathrm{TiO}_{2}$. These advanced building materials endowed buildings with desirable functionalities which ensured the improvement in construction quality. The details of the type of building materials that were developed using pristine/physically/chemically modified $\mathrm{TiO}_{2}$, the methodologies adopted, the tests that enabled the self-cleaning property, and the salient results of the published papers on the topic are tabulated for reference (Table 3). A few of the studies not listed in Table 3 are detailed as below.

$\mathrm{An} \mathrm{Au}-\mathrm{TiO}_{2} / \mathrm{SiO}_{2}$ coating was applied by a simple spraying method on two different building stones in the process of developing a self-cleaning BM [208]. The self-cleaning and depolluting properties were evaluated using soot and NO, respectively. The results informed that the highest photoactivity level was observed for coating formulations having smaller sized Au NPs $(\sim 13 \mathrm{~nm})$ and intermediate gold loading $\left(0.5 \% \mathrm{w} / \mathrm{w} \mathrm{Au} / \mathrm{TiO}_{2}\right)$. The self-cleaning and photocatalytic properties of a $\mathrm{TiO}_{2} / \mathrm{AuNRs}-\mathrm{SiO}_{2}$ coating on fossiliferous limestone (calcite $98.5 \%, \alpha$-quartz $1.5 \%$ ) were evaluated under a solar light irradiation condition with reference to MB discoloration and carbon soot removal [209]. An interesting observation in this work was the effect of calcination temperature on the self-cleaning and soot removal characteristics. A calcination temperature of $450{ }^{\circ} \mathrm{C}$ provided the best self-cleaning properties which was attributed to the increased contact between the $\mathrm{Au}$ and $\mathrm{SiO}_{2}$ particles.

In another work, effective and long-term $\mathrm{Au}-\mathrm{TiO}_{2} / \mathrm{SiO}_{2}$ coatings for $\mathrm{BMs}$ were developed by dispersing $\mathrm{Au}$ and $\mathrm{TiO}_{2}$ NPs into an initial sol containing a silica oligomer and $n$-octylamine [210]. The surfactant used in the formulation had multiple roles such as: to catalyze the sol-gel transition of the silica precursor, to generate a mesoporous silica gel network, and to increase the contact of contaminants to photoactive centers. An enhanced $\mathrm{TiO}_{2}$ photoactivity level was observed under solar 
radiation, even for the inclusion of a smaller amount of Au NPs into the self-cleaning coating, because of the absorption of a larger proportion of visible light $(\sim 45 \%)$.

Table 3. Summary of various $\mathrm{TiO}_{2}$ based pristine/modified building materials having self-cleaning properties, their preparation route, and salient results.

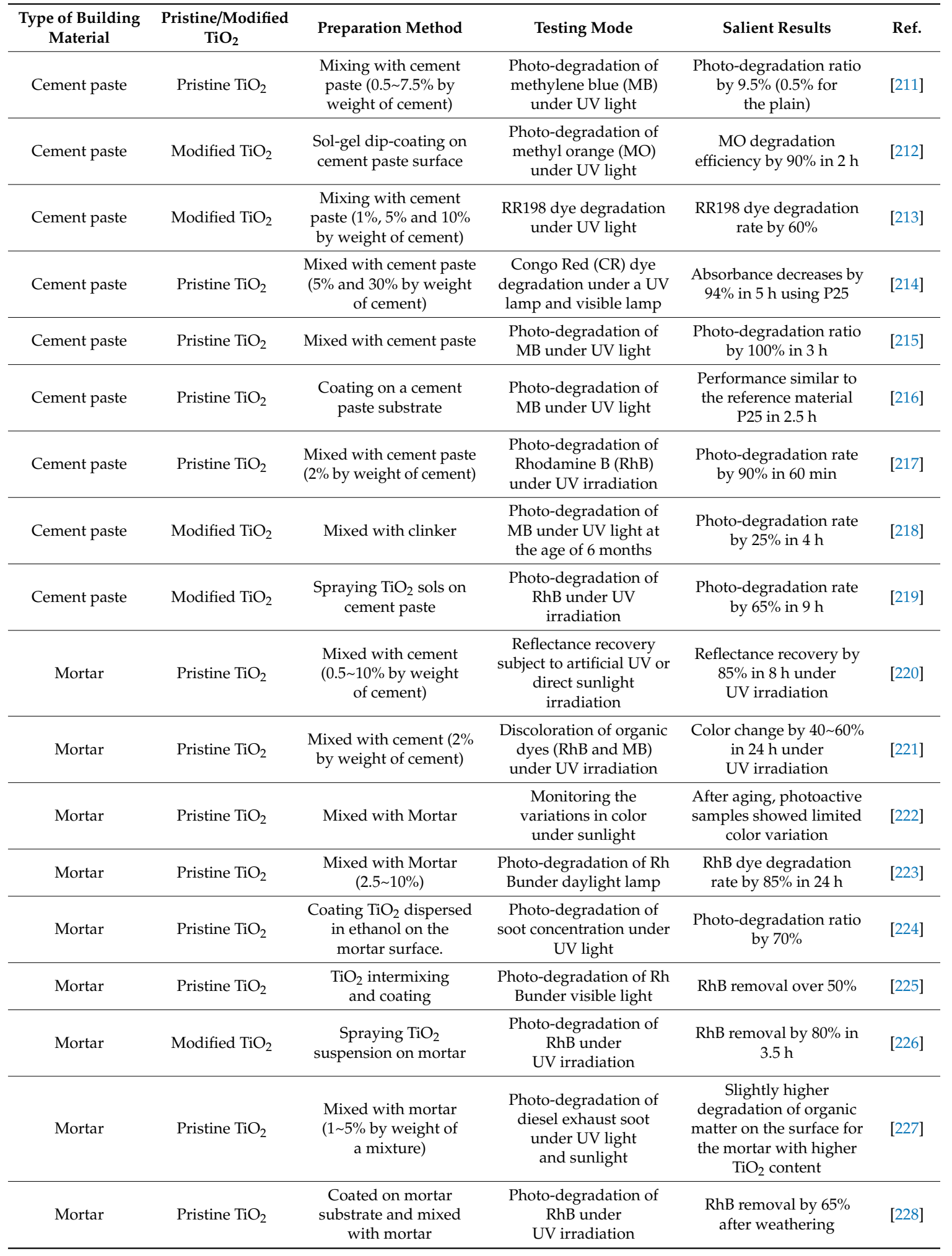


Table 3. Cont

\begin{tabular}{|c|c|c|c|c|c|}
\hline $\begin{array}{c}\text { Type of Building } \\
\text { Material }\end{array}$ & $\begin{array}{c}\text { Pristine/Modified } \\
\mathrm{TiO}_{2}\end{array}$ & Preparation Method & Testing Mode & Salient Results & Ref. \\
\hline Mortar & Modified $\mathrm{TiO}_{2}$ & $\begin{array}{l}\text { Mixed with mortar ( } 3 \% \\
\text { by weight of mortar) }\end{array}$ & $\begin{array}{c}\text { Photo-degradation of } \\
\text { RhB under } \\
\text { mercury lamp }\end{array}$ & $\begin{array}{l}\text { RhB removal by } 100 \% \\
\text { within } 1 \mathrm{~h}\end{array}$ & [229] \\
\hline Mortar & Pristine $\mathrm{TiO}_{2}$ & $\begin{array}{c}\text { Mixed with mortar }(2.5 \% \\
\text { and } 5 \% \text { by weight } \\
\text { of mortar })\end{array}$ & $\begin{array}{c}\text { Photo-degradation of } \\
\text { soot concentration under } \\
\text { UV light }\end{array}$ & $\begin{array}{c}\text { Promotion of } \\
\text { self-cleaning effect for } \\
\mathrm{TiO}_{2} \text {-containing mortars } \\
\text { after UVA irradiation. }\end{array}$ & [230] \\
\hline Mortar & Pristine $\mathrm{TiO}_{2}$ & $\begin{array}{l}\text { Use of ready-mixed } \\
\text { mortar containing } \mathrm{TiO}_{2}\end{array}$ & $\begin{array}{c}\text { Photo-degradation of } \\
\text { RhB under } \\
\text { UV irradiation }\end{array}$ & $\begin{array}{l}\text { RhB discoloration rate } \\
\text { by } 55 \% \text { in } 26 \mathrm{~h}\end{array}$ & [231] \\
\hline Mortar & Pristine $\mathrm{TiO}_{2}$ & $\begin{array}{l}\text { Spraying } \mathrm{TiO}_{2} \text { sols on } \\
\text { mortar surface }\end{array}$ & $\begin{array}{l}\text { Photo-degradation of } \mathrm{Rh} \\
\text { Bunder fluorescent lamp }\end{array}$ & $\begin{array}{l}\text { RhB photo-degradation } \\
\text { rate by } 100 \% \text { in } 5 \text { days }\end{array}$ & [130] \\
\hline Mortar & Modified $\mathrm{TiO}_{2}$ & $\begin{array}{l}\text { Mixed with mortar ( } 3 \% \\
\text { by weight of cement) }\end{array}$ & $\begin{array}{l}\text { Photo-degradation of } \\
\text { MB under UV light }\end{array}$ & $\begin{array}{l}\text { Photo-degradation rate } \\
\text { by } 35 \% \text { in } 4 \mathrm{~h}\end{array}$ & [232] \\
\hline Mortar & Pristine $\mathrm{TiO}_{2}$ & $\begin{array}{l}\text { Mixed with mortar }(2 \% \\
\text { by weight of cement) }\end{array}$ & $\begin{array}{l}\text { Nitroblue tetrazolium } \\
\text { (NBT) ink color change } \\
\text { under UV light }\end{array}$ & $\begin{array}{l}\text { NBT testing takes } \\
\text { substantially less time } \\
(10 \text { min }) \text { than } \\
\text { conventional } \\
\text { photocatalytic } \\
\text { activity tests }\end{array}$ & [233] \\
\hline Mortar & Modified $\mathrm{TiO}_{2}$ & $\begin{array}{l}\text { Dip-coating of } \mathrm{TiO}_{2} / \mathrm{SiO}_{2} \\
\text { sol on mortar surface }\end{array}$ & $\begin{array}{l}\text { Photo-degradation of } \\
\text { RhB under UV } \\
\text { irradiation }\end{array}$ & $\begin{array}{l}\text { Photo-degradation rate } \\
\text { by } 90 \% \text { in } 5 \mathrm{~h}\end{array}$ & [234] \\
\hline Concrete & $\begin{array}{l}\text { Pristine } \mathrm{TiO}_{2} \text { and } \\
\text { Modified } \mathrm{TiO}_{2}\end{array}$ & Spray and dip coating & $\begin{array}{l}\text { Photo-degradation of } \\
\text { MB under UV light }\end{array}$ & $\begin{array}{l}\text { MB degradation by } \\
5.2 \times 10^{-4} \text { pixels }^{-1}\end{array}$ & [114] \\
\hline Concrete & Pristine $\mathrm{TiO}_{2}$ & $\begin{array}{c}\text { Spraying } \mathrm{TiO}_{2} \\
\text { suspension on concrete }\end{array}$ & $\begin{array}{l}\text { Photo-degradation of } \\
\text { MO under UV light }\end{array}$ & $\begin{array}{c}\text { MO degradation } \\
\text { efficiency by } 100 \% \text { in } 2 \mathrm{~h}\end{array}$ & [237] \\
\hline Concrete & Modified $\mathrm{TiO}_{2}$ & $\begin{array}{l}\text { Coating on a concrete } \\
\text { substrate }\end{array}$ & $\begin{array}{l}\text { Photo-degradation of } \\
\text { MB under UV light }\end{array}$ & $\begin{array}{c}\text { Photo-degradation ratio } \\
\text { by } 100 \% \text { in } 5 \mathrm{~h}\end{array}$ & [238] \\
\hline Concrete & Pristine $\mathrm{TiO}_{2}$ & $\begin{array}{l}\text { Mixed with concrete } \\
\text { (3.5\% by weight } \\
\text { of cement) }\end{array}$ & $\begin{array}{l}\text { Photo-degradation of } \\
\text { MB under UV light }\end{array}$ & $\begin{array}{c}\text { Photo-degradation ratio } \\
\text { by } 82 \% \text { in } 26 \mathrm{~h}\end{array}$ & [239] \\
\hline Concrete & Modified $\mathrm{TiO}_{2}$ & $\begin{array}{l}\text { Spraying } \mathrm{TiO}_{2} \text { sols on } \\
\text { the concrete surface }\end{array}$ & $\begin{array}{l}\text { Photo-degradation of } \mathrm{Rh} \\
\text { Bunder natural } \\
\text { condition }\end{array}$ & $\begin{array}{l}\text { RhB photo-degradation } \\
\text { rate by } 30 \% \text { in } 24 \mathrm{~h} \text { (for } \\
\text { the specimen at the age } \\
\text { of } 2000 \mathrm{~h} \text { ) }\end{array}$ & [240] \\
\hline
\end{tabular}

\section{Issues and Limitations}

The achievement of long-term usage and high efficiency in PBMs are important goals for the commercial/practical utilization of PBMs. However, these goals are challenging to realize because of the inherent limitations of pristine $\mathrm{TiO}_{2}$ (visible light inactivity, high charge recombination rates, etc.) as well as the modifications in the properties of $\mathrm{TiO}_{2}$ (partial deactivation or blocking the active sites by intermediates or products) while PBMs are subjected for use in building environments. A few of the important issues that need to be resolved towards achieving high efficiency include (1) decreasing $\mathrm{e}^{-}-\mathrm{h}^{+}$ recombination rates, (2) increasing active sites on the surface of $\mathrm{TiO}_{2},(3)$ maximizing the dispersion of $\mathrm{TiO}_{2}$ within the matrix of the $\mathrm{BM}$ (cement, mortar, etc.), (4) optimization of cluster size and porosity, 
(5) ensuring of maximal photocatalytic activity for both large dyes and small gaseous molecules, (6) introduction of $\mathrm{TiO}_{2}$ in the form of an active mixed composition of its polymorphs (e.g., keeping suitable proportions of anatase and rutile phases), and (7) improving the pore structure of cement through control of the hydration process. Other factors that need to be considered include light sensitization of $\mathrm{TiO}_{2}$ by the other components present in the PBM, geographical applicability of PBMs (i.e., the influence of latitude, seasons, and time of the day on their photocatalytic performances), selectivity towards pollutant removal, the influence of photocatalytic reaction by-products, the adverse

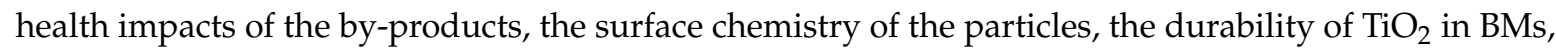
and dispersibility of $\mathrm{TiO}_{2}$ in cementitious materials.

The effects of $\mathrm{TiO}_{2}$ NPs on the inherent properties of hardened cement pastes and mortars are still to be thoroughly examined as the literature provided controversial information on the question of whether the addition of $\mathrm{TiO}_{2}$ introduces pozzolanic activity, or whether $\mathrm{TiO}_{2}$ acts simply as a non-reactive filler with photoactivities. A study which describes the preparation of $4 \% \mathrm{TiO}_{2}$ cement revealed the acceleration of calcium silicate hydrate (C-S-H) gel formation at the early stage of hydration and the consequent formation of crystalline calcium hydroxide [241]. The enhanced strength and improvements in the microstructure of the $\mathrm{TiO}_{2}$-added cement were observed [241]. These researchers came out with a conclusion that $\mathrm{TiO}_{2}$ acted simply as a non-reactive fine filler and did not generate any pozzolanic activity. However, $\mathrm{TiO}_{2}$ functioned as a nucleation site for the accumulation of hydration products. Further, the influence of $\mathrm{TiO}_{2} \mathrm{NPs}$ on the mechanical properties of cement-based composites is not clear. Generally, it is understood from the literature that the addition of nano- $\mathrm{TiO}_{2}$ particles decreased the setting time and improved the strength of mortars at early stages. On the other hand, the influence on the long-term mechanical properties of cured samples is disputable.

The various organic and/or inorganic compounds that are added while making PBMs influence their photocatalytic efficiency. It has been notified that the included inorganic or organic compounds within BMs degrade at varying rates, causing changes in the exposure of $\mathrm{TiO}_{2}$ to have light activation. Research indicated that stable refractory oxides and mineral acids present in BMs could bind to the catalyst surface and block catalytic sites [242]. The intermediates formed during the photocatalytic process could block the photoactivity of $\mathrm{TiO}_{2}$. Deactivation of $\mathrm{TiO}_{2}$ is a crucial disadvantage for the oxidation of VOCs or organic pollutants [243]. The poisoning effects of partially oxidized intermediates are believed to be responsible for this deactivation. A study informed that photocatalytic oxidation of the formation of partially oxidized intermediates (e.g., benzaldehyde and benzoic acid) during the photooxidation of toluene caused deactivation by blocking the activation sites [244]. Deactivation during ethanol and acetone PCO has also been reported [245-247]. These studies demonstrated the loss of photocatalytic activity as a result of oxidation of hydrocarbons, and suggested that partially oxidized intermediates are the reason for reduced photoactivity. Nevertheless, the encouraging fact is that these intermediates undergo slow photooxidation and, as a consequence, photoactivity can be restored upon continued exposure to oxidizing conditions. It should be noted that the high photocatalytic activity of $\mathrm{TiO}_{2}$ under UV light irradiation can also induce the inevitable degradation of surrounding materials, which ultimately causes the loss of appearance and severely decreases the lifetime of the paint [248]. For example, the unwanted photocatalytic reactions can either promote polymerization of the organic binder, creating cross-linking to result in embrittlement [249] or decompose the binder into VOC components. This could affect the surface of the building in the form of surface roughening and chalking. Besides, the photocatalytic degradation of pigments could cause discoloration [250].

$\mathrm{TiO}_{2}$-based nanocoatings could be applied to the external walls of buildings for their antibacterial and self-cleaning properties $[251,252]$. These photocatalytic coatings, when present on external surfaces in real-life conditions, are subjected to various mechanical solicitations and environmental weathering $[253,254]$. As a consequence, there could be a consequent loss of their structural integrity, resulting in the degradation of the BM. Furthermore, the disintegration of the structural material could result in the release of NPs into the gaseous or solution environments. It has been noted that $\mathrm{TiO}_{2}$ could convert atmospheric ammonia into toxic nitrogen oxides, which in turn contribute to the 
proliferation of urban smog [255]. In the process of broadening the practical applications of PBMs, a few promising strategies to improve the specific surface area of the photocatalysts have been attempted [256]. Studies have focused on creating a new class of nano-admixtures in cement-based composites. In this regard, the combination of nano-silica and $\mathrm{TiO}_{2}$ particles has been tried in order to synergistically derive the beneficial properties of both of them when included in cement-based composites $[229,257,258]$. Extensive research activities are demanded in these directions with economically viable materials.

\section{Conclusions and Future Perspectives}

The development of advanced building materials offers the opportunity to incorporate additional novel functionalities (such as self-cleaning, pollutant removal capability, durability in fluctuating climate, etc.) and provides a platform for addressing new challenges. These advanced building materials are judiciously integrated with new technologies in both residential and commercial buildings, in the process of developing smarter, more energy-efficient, and more secure infrastructures that will address environmental and global social challenges. Advanced building materials are utilized not only for resolving problems associated with indoor air pollution in buildings but also for mitigating gaseous emissions exceeding the allowable concentration in the atmosphere from traffic in the building's surrounding area. In this regard, scientific developments in modern material synthesis and nanotechnology provide an adequate platform for the design and creation of new and smart building materials with tailored properties.

Photocatalytic materials can degrade air pollutants and can also clean surfaces and act as a photoactive paint, mortar, etc. Concretes made with these types of materials are given primary importance for their applications in road infrastructures, such as lining and coatings for tunnels, and also accessories such as barriers and walls. A massive surge of research and commercial activities has prompted the production of building materials including photocatalytic $\mathrm{TiO}_{2}$ particles. In particular, $\mathrm{TiO}_{2}$ demonstrated its prominence for the development of photocatalytic building materials due to its advantageous characteristics that include ease of manufacturing or synthesis, non-toxic nature, less corrosive property, excellent chemical stability, low cost, and inherent photocatalytic properties. In general, the photoactive $\mathrm{TiO}_{2}$ in building materials absorbs ultraviolet rays and oxidizes most organic and some inorganic pollutants. The vast number of research activities that are being continuously conducted by researchers forms the basis for building engineers to design modern strategies towards conceiving advanced building materials. Portland blocks of cement containing $\mathrm{TiO}_{2}$ were developed and used in the form of pavements, concrete blocks, roof tiles, etc. Notably, the photoactive cement-coated walls removed air pollutants that can discolor exposed surfaces and added additional built-in functionalities, such as a self-cleaning property that supports the cleaning of residual products by rain or by the flow of water. $\mathrm{TiO}_{2}$-inclusive photoactive cement/binders meet many objectives, such as sustainability, self-cleaning of the surface coupled with redox reactions induced by sunlight or ultraviolet light, photo-induced hydrophilicity of the catalyst surface, mitigation of the urban heat island effect arising from the photocatalytic properties of these "cool" materials. Paved surfaces (e.g., highways, runways, parking lots, etc.) generally account for up to $\sim 60 \%$ of developed urban areas, and could be modified with a thin layer of $\mathrm{TiO}_{2}$-inclusive photocatalytic materials so that the topmost surface effectively clears the environment of the adverse effects of pollutants coupled through the influence of solar reflectance. In addition, a simple renovation of the top surface of pavements can regenerate their photoactive surface. Urban temperatures could be controlled by simply coating wall surfaces with white photocatalytic materials. Such applications can be extended to parking lots and roads to reduce temperatures and to cool the environment, as well as to improve air quality. Additionally, with the correlation between the formation of smog and the relative warmth of the environment, white photocatalytic coatings can also contribute to a reduction in ozone formation during the summer period. This effect will, in turn, result in the decrease in the kinetics rate for photochemical pollution reactions, and will consequently decrease the formation of secondary harmful substances. At a close glance at the market for $\mathrm{TiO}_{2}$-based photocatalytic building materials, a large number of 
companies (>2000) have developed building materials in the form of exterior construction materials (coated glass, paints, tiles, and tents), interior decoration products (antibacterial and self-cleaning tiles, smart windows, wallpapers, etc.), air purification systems (air cleaners, air conditioners, air cleaner hybrids, etc.), and water purification facilities (waste and sewage water purification). However, these developments have been made amidst several issues of using $\mathrm{TiO}_{2}$ as a photocatalyst, despite its various beneficial aspects.

One of the significant issues with $\mathrm{TiO}_{2}$ photocatalysis is the restricted visible light photoactivity for $\mathrm{TiO}_{2}$ due to the large bandgaps (3.0-3.2 eV) of traditional $\mathrm{TiO}_{2}$ materials. Together with the fact that $\mathrm{TiO}_{2}$ photoactivity is mainly centered on only the ultraviolet (UV) spectrum ( $3 \%$ of the solar irradiation received on Earth), there exists a great challenge in expanding the photoactivity of $\mathrm{TiO}_{2}$ into the visible region. Besides, the problem associated with the rapid spontaneous combination of photon-excited electrons and holes for traditional $\mathrm{TiO}_{2}$ materials should be circumvented for enhancing photoconversion efficiency under direct solar light. Thus, there is a continuous need for developing $\mathrm{TiO}_{2}$ photocatalysts with good charge separation, increased surface reactions, and extended optical absorption to visible light. Approaches that have been attempted towards achieving visible light active $\mathrm{TiO}_{2}$ include the modification of $\mathrm{TiO}_{2}$ via metal-ion implantation with transition metals, doping with metal or non-metal, compositing $\mathrm{TiO}_{2}$ with low bandgap semiconductor, $\mathrm{TiO}_{2}$ dye-sensitization, doping with luminescence materials and metal-nonmetal co-doping, etc. (Scheme 3). While the majority of the research activities on $\mathrm{TiO}_{2}$ modification for visible light activity have been reported in terms of the inclusion of the modifying precursor during sol-gel synthesis, limited studies were available on post-modification after $\mathrm{TiO}_{2}$ synthesis. Moreover, many of the modification approaches are time-consuming, constrained with multiple steps, and involve expensive modifier(s), which ultimately excludes the possibility of commercial building material production. Hence, research nees to focus on developing economically viable $\mathrm{TiO}_{2}$ modification procedures, especially for building material applications.

This review details the strategies that have been adopted for achieving high photocatalytic performance and visible light photoactivity for $\mathrm{TiO}_{2}$ in the last few years (2014-2019), including controlling the geometric shape or morphology of the particles, particle size, and porosity tuning, bandgap alteration, surface defects or disorder manipulations, phase composition control, etc., through chemical, physical, and mechanochemical approaches. Research activities focusing on enhancing photoactivity and improving visible light photoactivity, additional aspects, such as adsorption characteristics and surface hydrophilicity, and photocatalytic kinetics have not been adequately considered. Hence, further research activities are needed on these areas that have been neglected. Based on the basic and fundamental research activities, several advancements have been achieved regarding the use of $\mathrm{TiO}_{2}$ as a photocatalyst; in particular, improvements in photocatalytic efficiency, expansion of optical absorption to visible regions (solar light), and more straightforward chemical/physical modifications were made over the last few years. We believe that the knowledge gathered through the literature on these developments will form the basis for the development of advanced next-generation building materials. Besides, one can conceive more socially relevant applications for $\mathrm{TiO}_{2}$; as a part of its application in aspects of photocatalytic building materials, there needs to be extensive activity on the renovation of tunnels with advanced photocatalytic technology, as this would be beneficial in terms of the actual costs involved for refurbishment with paint and UV lighting systems. This application can also resolve the pollution problems of those who are residing in the vicinity. The photocatalytic cleaning of these types of activities would serve as a cheaper means of protecting the surroundings. This comprehensive review will hopefully be useful for scientists and engineers having the intention to translate basic research information into practical and commercial products for construction purposes. 
Author Contributions: A.-I.G. and J.-C.L.-Conceptualization, arrangement, and writing; G.S.-Literature collection, organization, analysis, and writing; K.-P.L.-Literature collection and writing; P.S.-Writing and analysis; R.D.-Writing; Y.-1.H.-Writing; K.-Y.A.-Writing; V.K.-Writing; W.-J.K.-Conceptualization, organization, and constructive suggestions. All authors have read and agreed to the published version of the manuscript.

Funding: This work was supported by the National Research Foundation of Korea (NRF), grant funded by the Korean government (No. NRF-2018R1A2B2003832).

Conflicts of Interest: The authors declare no conflict of interest.

\section{References}

1. Lelieveld, J.; Evans, J.S.; Fnais, M.; Giannadaki, D.; Pozzer, A. The contribution of outdoor air pollution sources to premature mortality on a global scale. Nature 2015, 525, 367-371. [CrossRef] [PubMed]

2. Nathanael, A.J.; Kannaiyan, K.; Kunhiraman, A.K.; Kumaravel, V. Nanomaterials for detection and removal of gases. In Nanomaterials for Sustainable Energy and Environmental Remediation; Naushad, M., Saravanan, R., Raju, K., Eds.; Elsevier: Amsterdam, The Netherlands, 2020; pp. 219-260. [CrossRef]

3. Gallego, E.; Roca, X.; Perales, J.F.; Guardino, X. Determining indoor air quality and identifying the origin of odour episodes in indoor environments. J. Environ. Sci. 2009, 21, 333-339. [CrossRef]

4. Tran, V.V.; Park, D.; Lee, Y.-C. Indoor Air Pollution, Related Human Diseases, and Recent Trends in the Control and Improvement of Indoor Air Quality. Int. J. Environ. Res. Public Health 2020, 17, 2927. [CrossRef] [PubMed]

5. Leung, D.Y.C. Outdoor-indoor air pollution in urban environment: Challenges and opportunity. Front. Environ. Sci. 2015, 2. [CrossRef]

6. He, C.; Cheng, J.; Zhang, X.; Douthwaite, M.; Pattisson, S.; Hao, Z. Recent Advances in the Catalytic Oxidation of Volatile Organic Compounds: A Review Based on Pollutant Sorts and Sources. Chem. Rev. 2019, 119, 4471-4568. [CrossRef] [PubMed]

7. Manisalidis, I.; Stavropoulou, E.; Stavropoulos, A.; Bezirtzoglou, E. Environmental and Health Impacts of Air Pollution: A Review. Front. Public Health 2020, 8, 14. [CrossRef] [PubMed]

8. Singh, P.; Borthakur, A. A review on biodegradation and photocatalytic degradation of organic pollutants: A bibliometric and comparative analysis. J. Clean. Prod. 2018, 196, 1669-1680. [CrossRef]

9. Lee, J.-S.; Yoon, N.-R.; Kang, B.-H.; Lee, S.-W.; Gopalan, S.-A.; Kim, S.-W.; Lee, S.-H.; Kwon, D.-H.; Kang, S.-W. Au-Polypyrrole Framework Nanostructures for Improved Localized Surface Plasmon Resonance Volatile Organic Compounds Gas Sensing. J. Nanosci. Nanotechnol. 2015, 15, 7738-7742. [CrossRef]

10. Hallquist, M.; Munthe, J.; Hu, M.; Wang, T.; Chan, C.K.; Gao, J.; Boman, J.; Guo, S.; Hallquist, Å.M.; Mellqvist, J.; et al. Photochemical smog in China: Scientific challenges and implications for air-quality policies. Natl. Sci. Rev. 2016, 3, 401-403. [CrossRef]

11. Qi, H.; Sun, D.Z.; Chi, G.Q. Formaldehyde degradation by $\mathrm{UV} / \mathrm{TiO}_{2} / \mathrm{O}_{3}$ process using continuous flow mode. J. Environ. Sci. 2007, 19, 1136-1140. [CrossRef]

12. Joseph, S.; Benzigar, M.R.; Ilbeygi, H.; Gopalan, S.A.; Lakhi, K.S.; Ramadass, K.; Talapaneni, S.N.; Vinu, A. Mesoporous Carbons with Hexagonally Ordered Pores Prepared from Carbonated Soft-Drink for $\mathrm{CO}_{2}$ Capture at High Pressure. J. Nanosci. Nanotechnol. 2018, 18, 7830-7837. [CrossRef]

13. Joseph, S.; Saianand, G.; Benzigar, M.R.; Ramadass, K.; Singh, G.; Gopalan, A.-I.; Yang, J.H.; Mori, T.; Al-Muhtaseb, A.a.H.; Yi, J.; et al. Recent Advances in Functionalized Nanoporous Carbons Derived from Waste Resources and Their Applications in Energy and Environment. Adv. Sustain. Syst. 2020, 2000169. [CrossRef]

14. Mamaghani, A.H.; Haghighat, F.; Lee, C.-S. Photocatalytic oxidation technology for indoor environment air purification: The state-of-the-art. Appl. Catal. B Environ. 2017, 203, 247-269. [CrossRef]

15. Lee, H.-G.; Sai-Anand, G.; Komathi, S.; Gopalan, A.-I.; Kang, S.-W.; Lee, K.-P. Efficient visible-light-driven photocatalytic degradation of nitrophenol by using graphene-encapsulated $\mathrm{TiO}_{2}$ nanowires. J. Hazard. Mater. 2015, 283, 400-409. [CrossRef] [PubMed]

16. Saianand, G.; Sonar, P.; Wilson, G.J.; Gopalan, A.-I.; Roy, V.A.L.; Unni, G.E.; Mamun Reza, K.; Bahrami, B.; Venkatramanan, K.; Qiao, Q. Current advancements on charge selective contact interfacial layers and electrodes in flexible hybrid perovskite photovoltaics. J. Energy Chem. 2021, 54, 151-173. [CrossRef] 
17. Lee, H.-G.; Gopalan, A.-I.; Sai-Anand, G.; Lee, B.-C.; Kang, S.-W.; Lee, K.-P. Facile synthesis of functionalized graphene-palladium nanoparticle incorporated multicomponent $\mathrm{TiO}_{2}$ composite nanofibers. Mater. Chem. Phys. 2015, 154, 125-136. [CrossRef]

18. Lang, X.; Saianand, G.; Fu, W.; Ramakrishna, S. Photocatalytic water splitting utilizing electrospun semiconductors for solar hydrogen generation: Fabrication, Modification and Performance. Bull. Chem. Soc. Jpn. 2020. [CrossRef]

19. Xu, B.; Sai-Anand, G.; Unni, G.E.; Jeong, H.-M.; Kim, J.-S.; Kim, S.-W.; Kwon, J.-B.; Bae, J.-H.; Kang, S.-W. Pyridine-based additive optimized P3HT:PC61BM nanomorphology for improved performance and stability in polymer solar cells. Appl. Surf. Sci. 2019, 484, 825-834. [CrossRef]

20. Xu, B.; Sai-Anand, G.; Jeong, H.-M.; Kim, S.-W.; Kim, J.-S.; Kwon, J.-B.; Kang, S.-W. Improving Air-Stability and Performance of Bulk Heterojunction Polymer Solar Cells Using Solvent Engineered Hole Selective Interlayer. Materials 2018, 11, 1143. [CrossRef]

21. Sai-Anand, G.; Dubey, A.; Gopalan, A.-I.; Venkatesan, S.; Ruban, S.; Reza, K.M.; Choi, J.; Lakhi, K.S.; Xu, B.; Qiao, Q.; et al. Additive assisted morphological optimization of photoactive layer in polymer solar cells. Sol. Energy Mater. Sol. Cells 2018, 182, 246-254. [CrossRef]

22. Xu, B.; Sai-Anand, G.; Gopalan, A.-I.; Qiao, Q.; Kang, S.-W. Improving Photovoltaic Properties of P3HT:IC60BA through the Incorporation of Small Molecules. Polymers 2018, 10, 121.

23. Gopalan, S.-A.; Gopalan, A.-I.; Vinu, A.; Lee, K.-P.; Kang, S.-W. A new optical-electrical integrated buffer layer design based on gold nanoparticles tethered thiol containing sulfonated polyaniline towards enhancement of solar cell performance. Sol. Energy Mater. Sol. Cells 2018, 174, 112-123. [CrossRef]

24. Kang, B.-H.; Kim, J.-S.; Lee, J.-S.; Lee, S.-W.; Sai-Anand, G.; Jeong, H.-M.; Lee, S.-H.; Kwon, D.-H.; Kang, S.-W. Solution Processable CdSe/ZnS Quantum Dots Light-Emitting Diodes Using ZnO Nanocrystal as Electron Transport Layer. J. Nanosci. Nanotechnol. 2015, 15, 7416-7420. [CrossRef]

25. Lee, S.-W.; Choi, K.-J.; Kang, B.-H.; Lee, J.-S.; Kim, S.-W.; Kwon, J.-B.; Gopalan, S.-A.; Bae, J.-H.; Kim, E.-S.; Kwon, D.-H.; et al. Low dark current and improved detectivity of hybrid ultraviolet photodetector based on carbon-quantum-dots/zinc-oxide-nanorod composites. Org. Electron. 2016, 39, 250-257. [CrossRef]

26. Lee, S.-W.; Cha, S.-H.; Choi, K.-J.; Kang, B.-H.; Lee, J.-S.; Kim, S.-W.; Kim, J.-S.; Jeong, H.-M.; Gopalan, S.-A.; Kwon, D.-H.; et al. Low Dark-Current, High Current-Gain of PVK/ZnO Nanoparticles Composite-Based UV Photodetector by PN-Heterojunction Control. Sensors 2016, 16, 74.

27. Jiang, Y.; Sai-Anand, G.; Xu, B.; Lee, J.-S.; Kim, S.-W.; Yeom, S.-H.; Bae, J.-H.; Kang, S.-W. Enhancing the Photovoltaic Performance of Polymer Solar Cells by Manipulating Photoactive/Metal Interface. J. Nanosci. Nanotechnol. 2017, 17, 8024-8030. [CrossRef]

28. Saianand, G.; Gopalan, A.-I.; Lee, J.-C.; Sathish, C.; Gopalakrishnan, K.; Unni, G.E.; Shanbhag, D.; Dasireddy, V.D.B.C.; Yi, J.; Xi, S.; et al. Mixed Copper/Copper-Oxide Anchored Mesoporous Fullerene Nanohybrids as Superior Electrocatalysts toward Oxygen Reduction Reaction. Small 2020, 16, 1903937. [CrossRef]

29. Karthikeyan, V.; Roy, V.A.L.; Gopalan, A.-I.; Saianand, G.; Kim, W.-J.; Kannan, V. A Comparative Evaluation of Physicochemical Properties and Photocatalytic Efficiencies of Cerium Oxide and Copper Oxide Nanofluids. Catalysts 2020, 10, 34.

30. Bui, Q.-T.; Yu, I.-K.; Gopalan, A.I.; Saianand, G.; Kim, W.; Choi, S.-H. Facile Fabrication of Metal Oxide Based Catalytic Electrodes by AC Plasma Deposition and Electrochemical Detection of Hydrogen Peroxide. Catalysts 2019, 9, 888 .

31. Sridara, T.; Upan, J.; Saianand, G.; Tuantranont, A.; Karuwan, C.; Jakmunee, J. Non-Enzymatic Amperometric Glucose Sensor Based on Carbon Nanodots and Copper Oxide Nanocomposites Electrode. Sensors 2020, 20, 808.

32. Lee, J.-C.; Gopalan, A.-I.; Saianand, G.; Lee, K.-P.; Kim, W.-J. Manganese and Graphene Included Titanium Dioxide Composite Nanowires: Fabrication, Characterization and Enhanced Photocatalytic Activities. Nanomaterials 2020, 10, 456. [CrossRef] [PubMed]

33. Lee, J.-C.; Gopalan, A.-I.; Sai-Anand, G.; Lee, K.-P.; Kim, W.-J. Preparation of Visible Light Photocatalytic Graphene Embedded Rutile Titanium(IV) Oxide Composite Nanowires and Enhanced NOx Removal. Catalysts 2019, 9, 170. [CrossRef]

34. Lee, H.-G.; Gopalan, A.-I.; Sai-Anand, G.; Kang, S.-W.; Lee, K.-P. New Heterojunction Titanium Dioxide Nanowire as Photocatalyst. J. Nanosci. Nanotechnol. 2015, 15, 7421-7425. [CrossRef] 
35. Haldorai, Y.; Hwang, S.-K.; Gopalan, A.-I.; Huh, Y.S.; Han, Y.-K.; Voit, W.; Sai-Anand, G.; Lee, K.-P. Direct electrochemistry of cytochrome c immobilized on titanium nitride/multi-walled carbon nanotube composite for amperometric nitrite biosensor. Biosens. Bioelectron. 2016, 79, 543-552. [CrossRef] [PubMed]

36. Bahrami, B.; Mabrouk, S.; Adhikari, N.; Elbohy, H.; Gurung, A.; Reza, K.M.; Pathak, R.; Chowdhury, A.H.; Saianand, G.; Yue, W.; et al. Nanoscale control of grain boundary potential barrier, dopant density and filled trap state density for higher efficiency perovskite solar cells. InfoMat 2020, 2, 409-423. [CrossRef]

37. Sai-Anand, G.; Sivanesan, A.; Benzigar, M.R.; Singh, G.; Gopalan, A.-I.; Baskar, A.V.; Ilbeygi, H.; Ramadass, K.; Kambala, V.; Vinu, A. Recent Progress on the Sensing of Pathogenic Bacteria Using Advanced Nanostructures. Bull. Chem. Soc. Jpn. 2019, 92, 216-244. [CrossRef]

38. Mamaghani, A.H.; Haghighat, F.; Lee, C.-S. Photocatalytic degradation of VOCs on various commercial titanium dioxides: Impact of operating parameters on removal efficiency and by-products generation. Build. Environ. 2018, 138, 275-282. [CrossRef]

39. Nakata, K.; Fujishima, A. $\mathrm{TiO}_{2}$ photocatalysis: Design and applications. J. Photochem. Photobiol. C Photochem. Rev. 2012, 13, 169-189. [CrossRef]

40. Dong, X.a.; Zhang, W.; Sun, Y.; Li, J.; Cen, W.; Cui, Z.; Huang, H.; Dong, F. Visible-light-induced charge transfer pathway and photocatalysis mechanism on Bi semimetal@defective BiOBr hierarchical microspheres. J. Catal. 2018, 357, 41-50. [CrossRef]

41. Li, X.; Zhang, W.; Cui, W.; Sun, Y.; Jiang, G.; Zhang, Y.; Huang, H.; Dong, F. Bismuth spheres assembled on graphene oxide: Directional charge transfer enhances plasmonic photocatalysis and in situ DRIFTS studies. Appl. Catal. B Environ. 2018, 221, 482-489. [CrossRef]

42. Wang, H.; Sun, Y.; Jiang, G.; Zhang, Y.; Huang, H.; Wu, Z.; Lee, S.C.; Dong, F. Unraveling the Mechanisms of Visible Light Photocatalytic NO Purification on Earth-Abundant Insulator-Based Core-Shell Heterojunctions. Environ. Sci. Technol. 2018, 52, 1479-1487. [CrossRef] [PubMed]

43. Wang, H.; He, W.; Dong, X.a.; Wang, H.; Dong, F. In situ FT-IR investigation on the reaction mechanism of visible light photocatalytic NO oxidation with defective $\mathrm{g}_{-} \mathrm{C}_{3} \mathrm{~N}_{4}$. Sci. Bull. 2018, 63, 117-125. [CrossRef]

44. Anand, G.S.; Gopalan, A.I.; Kang, S.-W.; Lee, K.-P. Development of a surface plasmon assisted label-free calorimetric method for sensitive detection of mercury based on functionalized gold nanorods. J. Anal. At. Spectrom. 2013, 28, 488-498. [CrossRef]

45. Haider, A.J.; Jameel, Z.N.; Al-Hussaini, I.H.M. Review on: Titanium Dioxide Applications. Energy Procedia 2019, 157, 17-29. [CrossRef]

46. Pérez-Lombard, L.; Ortiz, J.; Pout, C. A review on buildings energy consumption information. Energy Build. 2008, 40, 394-398. [CrossRef]

47. Kuo, C.-F.J.; Lin, C.-H.; Hsu, M.-W.; Li, M.-H. Evaluation of intelligent green building policies in TaiwanUsing fuzzy analytic hierarchical process and fuzzy transformation matrix. Energy Build. 2017, 139, 146-159. [CrossRef]

48. Younger, M.; Morrow-Almeida, H.R.; Vindigni, S.M.; Dannenberg, A.L. The Built Environment, Climate Change, and Health: Opportunities for Co-Benefits. Am. J. Prev. Med. 2008, 35, 517-526. [CrossRef] [PubMed]

49. Strini, A.; Cassese, S.; Schiavi, L. Measurement of benzene, toluene, ethylbenzene and o-xylene gas phase photodegradation by titanium dioxide dispersed in cementitious materials using a mixed flow reactor. Appl. Catal. B Environ. 2005, 61, 90-97. [CrossRef]

50. Demeestere, K.; Dewulf, J.; De Witte, B.; Beeldens, A.; Van Langenhove, H. Heterogeneous photocatalytic removal of toluene from air on building materials enriched with $\mathrm{TiO}_{2}$. Build. Environ. 2008, 43, 406-414. [CrossRef]

51. Maggos, T.; Bartzis, J.G.; Liakou, M.; Gobin, C. Photocatalytic degradation of NOx gases using TiO $_{2}$-containing paint: A real scale study. J. Hazard. Mater. 2007, 146, 668-673. [CrossRef]

52. Maggos, T.; Plassais, A.; Bartzis, J.G.; Vasilakos, C.; Moussiopoulos, N.; Bonafous, L. Photocatalytic degradation of $\mathrm{NOx}$ in a pilot street canyon configuration using $\mathrm{TiO}_{2}$-mortar panels. Environ. Monit. Assess. 2008, 136, 35-44. [CrossRef]

53. Binas, V.; Papadaki, D.; Maggos, T.; Katsanaki, A.; Kiriakidis, G. Study of innovative photocatalytic cement based coatings: The effect of supporting materials. Constr. Build. Mater. 2018, 168, 923-930. [CrossRef]

54. Silvestre, J.; Silvestre, N.; de Brito, J. Review on concrete nanotechnology. Eur. J. Environ. Civ. Eng. 2016, 20, 455-485. [CrossRef] 
55. Nath, R.K.; Zain, M.F.M.; Jamil, M. An environment-friendly solution for indoor air purification by using renewable photocatalysts in concrete: A review. Renew. Sustain. Energy Rev. 2016, 62, 1184-1194. [CrossRef]

56. Bastos, G.; Patiño-Barbeito, F.; Patiño-Cambeiro, F.; Armesto, J. Nano-Inclusions Applied in Cement-Matrix Composites: A Review. Materials (Basel) 2016, 9, 1015. [CrossRef] [PubMed]

57. Chen, J.; Poon, C.-S. Photocatalytic construction and building materials: From fundamentals to applications. Build. Environ. 2009, 44, 1899-1906. [CrossRef]

58. Perrin, M.L.; Verzijl, C.J.O.; Martin, C.A.; Shaikh, A.J.; Eelkema, R.; van Esch, J.H.; van Ruitenbeek, J.M.; Thijssen, J.M.; van der Zant, H.S.J.; Dulić, D. Large tunable image-charge effects in single-molecule junctions. Nat. Nanotechnol. 2013, 8, 282-287. [CrossRef]

59. Munafò, P.; Goffredo, G.B.; Quagliarini, E. $\mathrm{TiO}_{2}$-based nanocoatings for preserving architectural stone surfaces: An overview. Constr. Build. Mater. 2015, 84, 201-218. [CrossRef]

60. Antizar-Ladislao, B.; Galil, N.I. Biofilm and colloidal biomass dynamics in a shallow sandy contaminated aquifer under in-situ remediation conditions. Int. Biodeterior. Biodegrad. 2010, 64, 331-338. [CrossRef]

61. Cappelletti, G.; Fermo, P.; Camiloni, M. Smart hybrid coatings for natural stones conservation. Prog. Org. Coat. 2015, 78, 511-516. [CrossRef]

62. Franzoni, E.; Fregni, A.; Gabrielli, R.; Graziani, G.; Sassoni, E. Compatibility of photocatalytic $\mathrm{TiO}_{2}$-based finishing for renders in architectural restoration: A preliminary study. Build. Environ. 2014, 80, 125-135. [CrossRef]

63. Kapridaki, C.; Pinho, L.; Mosquera, M.J.; Maravelaki-Kalaitzaki, P. Producing photoactive, transparent and hydrophobic $\mathrm{SiO}_{2}$-crystalline $\mathrm{TiO}_{2}$ nanocomposites at ambient conditions with application as self-cleaning coatings. Appl. Catal. B Environ. 2014, 156-157, 416-427. [CrossRef]

64. Smits, M.; Chan, C.k.; Tytgat, T.; Craeye, B.; Costarramone, N.; Lacombe, S.; Lenaerts, S. Photocatalytic degradation of soot deposition: Self-cleaning effect on titanium dioxide coated cementitious materials. Chem. Eng. J. 2013, 222, 411-418. [CrossRef]

65. Quagliarini, E.; Bondioli, F.; Goffredo, G.B.; Licciulli, A.; Munafò, P. Self-cleaning materials on Architectural Heritage: Compatibility of photo-induced hydrophilicity of $\mathrm{TiO}_{2}$ coatings on stone surfaces. J. Cult. Herit. 2013, 14, 1-7. [CrossRef]

66. Gherardi, F.; Colombo, A.; D'Arienzo, M.; Di Credico, B.; Goidanich, S.; Morazzoni, F.; Simonutti, R.; Toniolo, L. Efficient self-cleaning treatments for built heritage based on highly photo-active and well-dispersible $\mathrm{TiO}_{2}$ nanocrystals. Microchem. J. 2016, 126, 54-62. [CrossRef]

67. Petronella, F.; Pagliarulo, A.; Striccoli, M.; Calia, A.; Lettieri, M.; Colangiuli, D.; Curri, M.L.; Comparelli, R. Colloidal Nanocrystalline Semiconductor Materials as Photocatalysts for Environmental Protection of Architectural Stone. Crystals 2017, 7, 30. [CrossRef]

68. Calia, A.; Lettieri, M.; Masieri, M. Durability assessment of nanostructured $\mathrm{TiO}_{2}$ coatings applied on limestones to enhance building surface with self-cleaning ability. Build. Environ. 2016, 110, 1-10. [CrossRef]

69. Lorenzo, G.; Enrico, Q.; Marco, D.O. Superfici autopulenti e biocide nel restauro archeologico di pietre e laterizi. Restauro Archeol. 2016, 24, 28-43. [CrossRef]

70. La Russa, M.F.; Rovella, N.; Alvarez de Buergo, M.; Belfiore, C.M.; Pezzino, A.; Crisci, G.M.; Ruffolo, S.A. Nano- $\mathrm{TiO}_{2}$ coatings for cultural heritage protection: The role of the binder on hydrophobic and self-cleaning efficacy. Prog. Org. Coat. 2016, 91, 1-8. [CrossRef]

71. Inkyo, M.; Tahara, T.; Iwaki, T.; Iskandar, F.; Hogan, C.J.; Okuyama, K. Experimental investigation of nanoparticle dispersion by beads milling with centrifugal bead separation. J. Colloid Interface Sci. 2006, 304, 535-540. [CrossRef]

72. Miao, J.; Zhang, R.; Zhang, L. Photocatalytic degradations of three dyes with different chemical structures using ball-milled $\mathrm{TiO}_{2}$. Mater. Res. Bull. 2018, 97, 109-114. [CrossRef]

73. He, R.; Huang, X.; Zhang, J.; Geng, Y.; Guo, H. Preparation and Evaluation of Exhaust-Purifying Cement Concrete Employing Titanium Dioxide. Materials 2019, 12, 2182. [CrossRef]

74. Kusters, K.A.; Pratsinis, S.E.; Thoma, S.G.; Smith, D.M. Energy-Size reduction laws for ultrasonic fragmentation. Powder Technol. 1994, 80, 253-263. [CrossRef]

75. Doktycz, S.; Suslick, K. Interparticle collisions driven by ultrasound. Science 1990, 247, 1067-1069. [CrossRef]

76. Zhang, G.; Yan, Y.; Hu, Z.; Xiao, B. Investigation on preparation of pyrite tailings-based mineral admixture with photocatalytic activity. Constr. Build. Mater. 2017, 138, 26-34. [CrossRef] 
77. Pérez-Nicolás, M.; Plank, J.; Ruiz-Izuriaga, D.; Navarro-Blasco, I.; Fernández, J.M.; Alvarez, J.I. Photocatalytically active coatings for cement and air lime mortars: Enhancement of the activity by incorporation of superplasticizers. Constr. Build. Mater. 2018, 162, 628-648. [CrossRef]

78. Lowke, D.; Gehlen, C. The zeta potential of cement and additions in cementitious suspensions with high solid fraction. Cem. Concr. Res. 2017, 95, 195-204. [CrossRef]

79. Quagliarini, E.; Bondioli, F.; Goffredo, G.B.; Cordoni, C.; Munafò, P. Self-cleaning and de-polluting stone surfaces: $\mathrm{TiO}_{2}$ nanoparticles for limestone. Constr. Build. Mater. 2012, 37, 51-57. [CrossRef]

80. Motter, J.S.; Miranda, L.F.R.; Bernucci, L.L.B. Performance of Hot Mix Asphalt Concrete Produced with Coarse Recycled Concrete Aggregate. J. Mater. Civ. Eng. 2015, 27, 04015030. [CrossRef]

81. Lee, B.Y.; Kurtis, K.E. Influence of $\mathrm{TiO}_{2}$ Nanoparticles on Early C3S Hydration. J. Am. Ceram. Soc. 2010, 93, 3399-3405. [CrossRef]

82. Koelsch, M.; Cassaignon, S.; Ta Thanh Minh, C.; Guillemoles, J.F.; Jolivet, J.P. Electrochemical comparative study of titania (anatase, brookite and rutile) nanoparticles synthesized in aqueous medium. Thin Solid Film. 2004, 451-452, 86-92. [CrossRef]

83. Nolan, N.T.; Seery, M.K.; Pillai, S.C. Spectroscopic Investigation of the Anatase-to-Rutile Transformation of Sol-Gel-Synthesized $\mathrm{TiO}_{2}$ Photocatalysts. J. Phys. Chem. C 2009, 113, 16151-16157. [CrossRef]

84. Cassar, L. Photocatalysis of Cementitious Materials: Clean Buildings and Clean Air. Mrs Bull. 2004, 29, 328-331. [CrossRef]

85. Humayun, M.; Raziq, F.; Khan, A.; Luo, W. Modification strategies of $\mathrm{TiO}_{2}$ for potential applications in photocatalysis: A critical review. Green Chem. Lett. Rev. 2018, 11, 86-102. [CrossRef]

86. Adormaa, B.B.; Darkwah, W.K.; Ao, Y. Oxygen vacancies of the $\mathrm{TiO}_{2}$ nano-based composite photocatalysts in visible light responsive photocatalysis. RSC Adv. 2018, 8, 33551-33563. [CrossRef]

87. Rehman, S.; Ullah, R.; Butt, A.M.; Gohar, N.D. Strategies of making $\mathrm{TiO}_{2}$ and $\mathrm{ZnO}$ visible light active. J. Hazard. Mater. 2009, 170, 560-569. [CrossRef]

88. Mittal, A.; Mari, B.; Sharma, S.; Kumari, V.; Maken, S.; Kumari, K.; Kumar, N. Non-metal modified TiO ${ }_{2}$ : A step towards visible light photocatalysis. J. Mater. Sci. Mater. Electron. 2019, 30, 3186-3207. [CrossRef]

89. Zhang, G.; Zhang, Y.C.; Nadagouda, M.; Han, C.; O'Shea, K.; El-Sheikh, S.M.; Ismail, A.A.; Dionysiou, D.D. Visible light-sensitized $\mathrm{S}, \mathrm{N}$ and $\mathrm{C}$ co-doped polymorphic $\mathrm{TiO}_{2}$ for photocatalytic destruction of microcystin-LR. Appl. Catal. B Environ. 2014, 144, 614-621. [CrossRef]

90. Bessegato, G.G.; Cardoso, J.C.; Zanoni, M.V.B. Enhanced photoelectrocatalytic degradation of an acid dye with boron-doped $\mathrm{TiO}_{2}$ nanotube anodes. Catal. Today 2015, 240, 100-106. [CrossRef]

91. Truppi, A.; Petronella, F.; Placido, T.; Striccoli, M.; Agostiano, A.; Curri, M.L.; Comparelli, R. Visible-LightActive $\mathrm{TiO}_{2}$-Based Hybrid Nanocatalysts for Environmental Applications. Catalysts 2017, 7, 100. [CrossRef]

92. Medhi, R.; Marquez, M.D.; Lee, T.R. Visible-Light-Active Doped Metal Oxide Nanoparticles: Review of their Synthesis, Properties, and Applications. ACS Appl. Nano Mater. 2020, 3, 6156-6185. [CrossRef]

93. Wang, S.; Ding, Z.; Chang, X.; Xu, J.; Wang, D.-H. Modified Nano-TiO 2 Based Composites for Environmental Photocatalytic Applications. Catalysts 2020, 10, 759.

94. Kumar, A.; Khan, M.; He, J.; Lo, I.M.C. Recent developments and challenges in practical application of visible-light-driven $\mathrm{TiO}_{2}$-based heterojunctions for PPCP degradation: A critical review. Water Res. 2020, 170, 115356. [CrossRef] [PubMed]

95. Liao, C.; Li, Y.; Tjong, S.C. Visible-Light Active Titanium Dioxide Nanomaterials with Bactericidal Properties. Nanomaterials 2020, 10, 124. [CrossRef] [PubMed]

96. Majumdar, A.; Pal, A. Recent advancements in visible-light-assisted photocatalytic removal of aqueous pharmaceutical pollutants. Clean Technol. Environ. Policy 2020, 22, 11-42. [CrossRef]

97. Higashimoto, S. Titanium-Dioxide-Based Visible-Light-Sensitive Photocatalysis: Mechanistic Insight and Applications. Catalysts 2019, 9, 201. [CrossRef]

98. Laufs, S.; Burgeth, G.; Duttlinger, W.; Kurtenbach, R.; Maban, M.; Thomas, C.; Wiesen, P.; Kleffmann, J. Conversion of nitrogen oxides on commercial photocatalytic dispersion paints. Atmos. Environ. 2010, 44, 2341-2349. [CrossRef]

99. National Institute for Occupational Safety and Health (NIOSH). NIOSH Pocket Guide to Chemical Hazards. DHHS (NIOSH) Publication No. 97-140; US Government Printing Office: Washington, DC, USA, 1997.

100. Zouzelka, R.; Rathousky, J. Photocatalytic abatement of $\mathrm{NO}_{\mathbf{x}}$ pollutants in the air using commercial functional coating with porous morphology. Appl. Catal. B Environ. 2017, 217, 466-476. [CrossRef] 
101. Lasek, J.; Yu, Y.-H.; Wu, J.C.S. Removal of $\mathrm{NO}_{\mathrm{x}}$ by photocatalytic processes. J. Photochem. Photobiol. C Photochem. Rev. 2013, 14, 29-52. [CrossRef]

102. Ehrlich, R. Effect of nitrogen dioxide on resistance to respiratory infection. Bacteriol. Rev. 1966, 30, 604-614. [CrossRef] [PubMed]

103. Kumaravel, V.; Mathew, S.; Bartlett, J.; Pillai, S.C. Photocatalytic hydrogen production using metal doped $\mathrm{TiO}_{2}$ : A review of recent advances. Appl. Catal. B Environ. 2019, 244, 1021-1064. [CrossRef]

104. Poon, C.S.; Cheung, E. NO removal efficiency of photocatalytic paving blocks prepared with recycled materials. Constr. Build. Mater. 2007, 21, 1746-1753. [CrossRef]

105. Sopyan, I.; Watanabe, M.; Murasawa, S.; Hashimoto, K.; Fujishima, A. An efficient $\mathrm{TiO}_{2}$ thin-film photocatalyst: Photocatalytic properties in gas-phase acetaldehyde degradation. J. Photochem. Photobiol. A Chem. 1996, 98, 79-86. [CrossRef]

106. TioCem ${ }^{\circledR}$ _High Tech Cement for the Reduction of Air Pollutants. 2008. Available online: https://www. yumpu.com/en/document/view/22223710/tiocem-heidelbergcement (accessed on 10 September 2020).

107. Calia, A.; Lettieri, M.; Masieri, M.; Pal, S.; Licciulli, A.; Arima, V. Limestones coated with photocatalytic $\mathrm{TiO}_{2}$ to enhance building surface with self-cleaning and depolluting abilities. J. Clean. Prod. 2017, 165, 1036-1047. [CrossRef]

108. Lettieri, M.; Colangiuli, D.; Masieri, M.; Calia, A. Field performances of nanosized $\mathrm{TiO}_{2}$ coated limestone for a self-cleaning building surface in an urban environment. Build. Environ. 2019, 147, 506-516. [CrossRef]

109. Marco, G.; Bo, X. Air Quality Legislation and Standards in the European Union: Background, Status and Public Participation. Adv. Clim. Chang. Res. 2013, 4, 50-59. [CrossRef]

110. Baral, A.; Sen, S.; Roesler, J.R. Use phase assessment of photocatalytic cool pavements. J. Clean. Prod. 2018, 190, 722-728. [CrossRef]

111. Mothes, F.; Ifang, S.; Gallus, M.; Golly, B.; Boréave, A.; Kurtenbach, R.; Kleffmann, J.; George, C.; Herrmann, H. Bed flow photoreactor experiments to assess the photocatalytic nitrogen oxides abatement under simulated atmospheric conditions. Appl. Catal. B Environ. 2018, 231, 161-172. [CrossRef]

112. Pérez-Nicolás, M.; Navarro-Blasco, I.; Fernández, J.M.; Alvarez, J.I. Atmospheric NOx removal: Study of cement mortars with iron- and vanadium-doped $\mathrm{TiO}_{2}$ as visible light-sensitive photocatalysts. Constr. Build. Mater. 2017, 149, 257-271. [CrossRef]

113. Seo, D.; Yun, T.S. NOx removal rate of photocatalytic cementitious materials with $\mathrm{TiO}_{2}$ in wet condition. Build. Environ. 2017, 112, 233-240. [CrossRef]

114. Faraldos, M.; Kropp, R.; Anderson, M.A.; Sobolev, K. Photocatalytic hydrophobic concrete coatings to combat air pollution. Catal. Today 2016, 259, 228-236. [CrossRef]

115. Lee, B.Y.; Jayapalan, A.R.; Bergin, M.H.; Kurtis, K.E. Photocatalytic cement exposed to nitrogen oxides: Effect of oxidation and binding. Cem. Concr. Res. 2014, 60, 30-36. [CrossRef]

116. Guo, M.-Z.; Chen, J.; Xia, M.; Wang, T.; Poon, C.S. Pathways of conversion of nitrogen oxides by nano $\mathrm{TiO}_{2}$ incorporated in cement-based materials. Build. Environ. 2018, 144, 412-418. [CrossRef]

117. Chen, J.; Poon, C.-S. Photocatalytic activity of titanium dioxide modified concrete materials-Influence of utilizing recycled glass cullets as aggregates. J. Environ. Manag. 2009, 90, 3436-3442. [CrossRef]

118. Dewi, K.; Khair, H.; Irsyad, M. Development of Green Pavement for Reducing Oxides of Nitrogen (NOx) in the Ambient Air. J. Eng. Technol. Sci. 2016, 48, 159-172. [CrossRef]

119. Wang, D.; Leng, Z.; Hüben, M.; Oeser, M.; Steinauer, B. Photocatalytic pavements with epoxy-bonded $\mathrm{TiO}_{2}$-containing spreading material. Constr. Build. Mater. 2016, 107, 44-51. [CrossRef]

120. Pérez-Nicolás, M.; Navarro-Blasco, I.; Fernández, J.M.; Alvarez, J.I. The Effect of $\mathrm{TiO}_{2}$ Doped Photocatalytic Nano-Additives on the Hydration and Microstructure of Portland and High Alumina Cements. Nanomaterials 2017, 7, 329. [CrossRef]

121. Janus, M.; Bubacz, K.; Zatorska, J.; Kusiak-Nejman, E.; Czyżewski, A.; Morawski, A.W. NOx photocatalytic degradation on gypsum plates modified by $\mathrm{TiO}_{2}-\mathrm{N}, \mathrm{C}$ photocatalysts. Pol. J. Chem. Technol. 2015, 17, 8-12. [CrossRef]

122. Xu, M.; Bao, Y.; Wu, K.; Shi, H.; Guo, X.; Li, V.C. Multiscale investigation of tensile properties of a $\mathrm{TiO}_{2}$-doped Engineered Cementitious Composite. Constr. Build. Mater. 2019, 209, 485-491. [CrossRef] 
123. Truffier-Boutry, D.; Fiorentino, B.; Bartolomei, V.; Soulas, R.; Sicardy, O.; Benayad, A.; Damlencourt, J.F.; Pépin-Donat, B.; Lombard, C.; Gandolfo, A.; et al. Characterization of photocatalytic paints: A relationship between the photocatalytic properties-Release of nanoparticles and volatile organic compounds. Environ. Sci. Nano 2017, 4, 1998-2009. [CrossRef]

124. Anantha-Iyengar, G.; Shanmugasundaram, K.; Nallal, M.; Lee, K.-P.; Whitcombe, M.J.; Lakshmi, D.; Sai-Anand, G. Functionalized conjugated polymers for sensing and molecular imprinting applications. Prog. Polym. Sci. 2019, 88, 1-129. [CrossRef]

125. Bonnefond, A.; González, E.; Asua, J.M.; Leiza, J.R.; Ieva, E.; Brinati, G.; Carella, S.; Marrani, A.; Veneroni, A.; Kiwi, J.; et al. Stable Photocatalytic Paints Prepared from Hybrid Core-Shell Fluorinated/Acrylic/TiO 2 Waterborne Dispersions. Crystals 2016, 6, 136. [CrossRef]

126. Paolini, R.; Sleiman, M.; Pedeferri, M.; Diamanti, M.V. $\mathrm{TiO}_{2}$ alterations with natural aging: Unveiling the role of nitric acid on NIR reflectance. Sol. Energy Mater. Sol. Cells 2016, 157, 791-797. [CrossRef]

127. Manzhos, S.; Giorgi, G.; Yamashita, K. A Density Functional Tight Binding Study of Acetic Acid Adsorption on Crystalline and Amorphous Surfaces of Titania. Molecules 2015, 20, 3371-3388. [CrossRef]

128. Guo, M.-Z.; Maury-Ramirez, A.; Poon, C.S. Versatile photocatalytic functions of self-compacting architectural glass mortars and their inter-relationship. Mater. Des. 2015, 88, 1260-1268. [CrossRef]

129. Gandolfo, A.; Bartolomei, V.; Gomez Alvarez, E.; Tlili, S.; Gligorovski, S.; Kleffmann, J.; Wortham, H. The effectiveness of indoor photocatalytic paints on $\mathrm{NO}_{\mathrm{x}}$ and $\mathrm{HONO}$ levels. Appl. Catal. B Environ. 2015, 166-167, 84-90. [CrossRef]

130. Mendoza, C.; Valle, A.; Castellote, M.; Bahamonde, A.; Faraldos, M. $\mathrm{TiO}_{2}$ and $\mathrm{TiO}_{2}-\mathrm{SiO}_{2}$ coated cement: Comparison of mechanic and photocatalytic properties. Appl. Catal. B Environ. 2015, 178, 155-164. [CrossRef]

131. Ângelo, J.; Andrade, L.; Mendes, A. Highly active photocatalytic paint for $\mathrm{NO}_{\mathrm{x}}$ abatement under real-outdoor conditions. Appl. Catal. A Gen. 2014, 484, 17-25. [CrossRef]

132. Luna, M.; Gatica, J.M.; Vidal, H.; Mosquera, M.J. Au- $-\mathrm{TiO}_{2} / \mathrm{SiO}_{2}$ photocatalysts with NOx depolluting activity: Influence of gold particle size and loading. Chem. Eng. J. 2019, 368, 417-427. [CrossRef]

133. Luna, M.; Gatica, J.M.; Vidal, H.; Mosquera, M.J. One-pot synthesis of $\mathrm{Au} / \mathrm{N}-\mathrm{TiO}_{2}$ photocatalysts for environmental applications: Enhancement of dyes and $\mathrm{NO}_{x}$ photodegradation. Powder Technol. 2019, 355, 793-807. [CrossRef]

134. Luna, M.; Gatica, J.M.; Vidal, H.; Mosquera, M.J. Use of $\mathrm{Au} / \mathrm{N}-\mathrm{TiO}_{2} / \mathrm{SiO}_{2}$ photocatalysts in building materials with NO depolluting activity. J. Clean. Prod. 2020, 243, 118633. [CrossRef]

135. Lee, J.-S.; Yoon, N.-R.; Kang, B.-H.; Lee, S.-W.; Gopalan, S.-A.; Jeong, H.-M.; Lee, S.-H.; Kwon, D.-H.; Kang, S.-W. Response Characterization of a Fiber Optic Sensor Array with Dye-Coated Planar Waveguide for Detection of Volatile Organic Compounds. Sensors 2014, 14, 11659-11671. [CrossRef] [PubMed]

136. Jedrychowski, W.; Perera, F.; Mrozek-Budzyn, D.; Mroz, E.; Flak, E.; Spengler, J.D.; Edwards, S.; Jacek, R.; Kaim, I.; Skolicki, Z. Gender differences in fetal growth of newborns exposed prenatally to airborne fine particulate matter. Environ. Res. 2009, 109, 447-456. [CrossRef] [PubMed]

137. Yang, X.; Srebric, J.; Li, X.; He, G. Performance of three air distribution systems in VOC removal from an area source. Build. Environ. 2004, 39, 1289-1299. [CrossRef]

138. Weschler, C.J. Changes in indoor pollutants since the 1950s. Atmos. Environ. 2009, 43, 153-169. [CrossRef]

139. Huang, Y.; Ho, S.S.H.; Lu, Y.; Niu, R.; Xu, L.; Cao, J.; Lee, S. Removal of Indoor Volatile Organic Compounds via Photocatalytic Oxidation: A Short Review and Prospect. Molecules 2016, 21, 56. [CrossRef]

140. Schneider, J.; Matsuoka, M.; Takeuchi, M.; Zhang, J.; Horiuchi, Y.; Anpo, M.; Bahnemann, D.W. Understanding $\mathrm{TiO}_{2}$ Photocatalysis: Mechanisms and Materials. Chem. Rev. 2014, 114, 9919-9986. [CrossRef]

141. Mo, J.; Zhang, Y.; Xu, Q.; Lamson, J.J.; Zhao, R. Photocatalytic purification of volatile organic compounds in indoor air: A literature review. Atmos. Environ. 2009, 43, 2229-2246. [CrossRef]

142. Colmenares, J.C.; Magdziarz, A.; Łomot, D.; Chernyayeva, O.; Lisovytskiy, D. A new photocatalytic tool in VOCs abatement: Effective synergetic combination of sonication and light for the synthesis of monometallic palladium-containing $\mathrm{TiO}_{2}$. Appl. Catal. B Environ. 2014, 147, 624-632. [CrossRef]

143. Abbas, N.; Hussain, M.; Russo, N.; Saracco, G. Studies on the activity and deactivation of novel optimized $\mathrm{TiO}_{2}$ nanoparticles for the abatement of VOCs. Chem. Eng. J. 2011, 175, 330-340. [CrossRef]

144. Yao, N.; Lun Yeung, K. Investigation of the performance of $\mathrm{TiO}_{2}$ photocatalytic coatings. Chem. Eng. J. 2011, 167, 13-21. [CrossRef] 
145. Freyria, F.S.; Compagnoni, M.; Ditaranto, N.; Rossetti, I.; Piumetti, M.; Ramis, G.; Bonelli, B. Pure and Fe-Doped Mesoporous Titania Catalyse the Oxidation of Acid Orange 7 by $\mathrm{H}_{2} \mathrm{O}_{2}$ under Different Illumination Conditions: Fe Doping Improves Photocatalytic Activity under Simulated Solar Light. Catalysts 2017, 7, 213. [CrossRef]

146. Song, I.; Lee, J.; Lee, G.; Han, J.W.; Kim, D.H. Chemisorption of $\mathrm{NH}_{3}$ on Monomeric Vanadium Oxide Supported on Anatase $\mathrm{TiO}_{2}$ : A Combined DRIFT and DFT Study. J. Phys. Chem. C 2018, 122, 16674-16682. [CrossRef]

147. Balci Leinen, M.; Dede, D.; Khan, M.U.; Çağlayan, M.; Koçak, Y.; Demir, H.V.; Ozensoy, E. CdTe Quantum Dot-Functionalized P25 Titania Composite with Enhanced Photocatalytic NO2 Storage Selectivity under UV and Vis Irradiation. ACS Appl. Mater. Interfaces 2019, 11, 865-879. [CrossRef]

148. Saeli, M.; Piccirillo, C.; Tobaldi, D.M.; Binions, R.; Castro, P.M.L.; Pullar, R.C. A sustainable replacement for $\mathrm{TiO}_{2}$ in photocatalyst construction materials: Hydroxyapatite-based photocatalytic additives, made from the valorisation of food wastes of marine origin. J. Clean. Prod. 2018, 193, 115-127. [CrossRef]

149. Tawari, A.; Einicke, W.-D.; Gläser, R. Photocatalytic Oxidation of NO over Composites of Titanium Dioxide and Zeolite ZSM-5. Catalysts 2016, 6, 31. [CrossRef]

150. Dinh, C.-T.; Hoogland, S.; Sargent, E.H. Spontaneous and Light-Driven Conversion of NOx on Oxide-Modified $\mathrm{TiO}_{2}$ Surfaces. Ind. Eng. Chem. Res. 2015, 54, 12750-12756. [CrossRef]

151. Yamamoto, A.; Mizuno, Y.; Teramura, K.; Hosokawa, S.; Tanaka, T. Surface Ba species effective for photoassisted $\mathrm{NOx}$ storage over Ba-modified $\mathrm{TiO}_{2}$ photocatalysts. Appl. Catal. B Environ. 2016, 180, $283-290$. [CrossRef]

152. Tran, T.; Yu, J.; Gan, L.; Guo, F.; Phan, D.; Xu, G. Upgrading $\mathrm{V}_{2} \mathrm{O}_{5}-\mathrm{WO}_{3} / \mathrm{TiO}_{2}$ deNO $\mathrm{N}_{\mathrm{x}}$ Catalyst with $\mathrm{TiO}_{2}-\mathrm{SiO}_{2}$ Support Prepared from Ti-Bearing Blast Furnace Slag. Catalysts 2016, 6, 56. [CrossRef]

153. Jõgi, I.; Stamate, E.; Irimiea, C.; Schmidt, M.; Brandenburg, R.; Hołub, M.; Bonisławski, M.; Jakubowski, T.; Kääriäinen, M.-L.; Cameron, D.C. Comparison of direct and indirect plasma oxidation of NO combined with oxidation by catalyst. Fuel 2015, 144, 137-144. [CrossRef]

154. Ma, J.; He, H.; Liu, F. Effect of Fe on the photocatalytic removal of $\mathrm{NO}_{x}$ over visible light responsive $\mathrm{Fe} / \mathrm{TiO} \mathrm{O}_{2}$ catalysts. Appl. Catal. B Environ. 2015, 179, 21-28. [CrossRef]

155. Zhu, W.; Xiao, S.; Zhang, D.; Liu, P.; Zhou, H.; Dai, W.; Liu, F.; Li, H. Highly Efficient and Stable $\mathrm{Au} / \mathrm{CeO}_{2}-\mathrm{TiO}_{2}$ Photocatalyst for Nitric Oxide Abatement: Potential Application in Flue Gas Treatment. Langmuir 2015, 31, 10822-10830. [CrossRef] [PubMed]

156. Polat, M.; Soylu, A.M.; Erdogan, D.A.; Erguven, H.; Vovk, E.I.; Ozensoy, E. Influence of the sol-gel preparation method on the photocatalytic $\mathrm{NO}$ oxidation performance of $\mathrm{TiO}_{2} / \mathrm{Al}_{2} \mathrm{O}_{3}$ binary oxides. Catal. Today 2015, 241, 25-32. [CrossRef]

157. Estudillo-Wong, L.A.; Arce-Estrada, E.M.; Manzo-Robledo, A. Interaction of NO during cathodic polarization in alkaline conditions at the interface of Pt-nanostructures supported on $\mathrm{C}$ and $\mathrm{TiO}_{2}-\mathrm{C}$. Electrochim. Acta 2014, 134, 100-106. [CrossRef]

158. Giampiccolo, A.; Tobaldi, D.M.; Leonardi, S.G.; Murdoch, B.J.; Seabra, M.P.; Ansell, M.P.; Neri, G.; Ball, R.J. Sol gel graphene/ $\mathrm{TiO}_{2}$ nanoparticles for the photocatalytic-assisted sensing and abatement of $\mathrm{NO}_{2}$. Appl. Catal. B Environ. 2019, 243, 183-194. [CrossRef]

159. Trapalis, A.; Todorova, N.; Giannakopoulou, T.; Boukos, N.; Speliotis, T.; Dimotikali, D.; Yu, J. TiO $2 /$ graphene composite photocatalysts for $\mathrm{NO}_{x}$ removal: A comparison of surfactant-stabilized graphene and reduced graphene oxide. Appl. Catal. B Environ. 2016, 180, 637-647. [CrossRef]

160. Liao, L.; Heylen, S.; Vallaey, B.; Keulemans, M.; Lenaerts, S.; Roeffaers, M.B.J.; Martens, J.A. Photocatalytic carbon oxidation with nitric oxide. Appl. Catal. B Environ. 2015, 166-167, 374-380. [CrossRef]

161. Huang, Y.; Wang, P.; Wang, Z.; Rao, Y.; Cao, J.-j.; Pu, S.; Ho, W.; Lee, S.C. Protonated g- $\mathrm{C}_{3} \mathrm{~N}_{4} / \mathrm{Ti}_{3+}$ self-doped $\mathrm{TiO}_{2}$ nanocomposite films: Room-temperature preparation, hydrophilicity, and application for photocatalytic NOx removal. Appl. Catal. B Environ. 2019, 240, 122-131. [CrossRef]

162. Rozman, N.; Tobaldi, D.M.; Cvelbar, U.; Puliyalil, H.; Labrincha, J.A.; Legat, A.; Sever Škapin, A. Hydrothermal Synthesis of Rare-Earth Modified Titania: Influence on Phase Composition, Optical Properties, and Photocatalytic Activity. Materials 2019, 12, 713. [CrossRef]

163. Silvestri, S.; Szpoganicz, B.; Schultz, J.; Mangrich, A.S.; Hotza, D.; García, D.E.; Labrincha, J.A. Doped and undoped anatase-based plates obtained from paper templates for photocatalytic oxidation of $\mathrm{NO}_{X}$. Ceram. Int. 2016, 42, 12074-12083. [CrossRef] 
164. Jeon, K.-Y.; Kim, W.-J.; Lee, C.-J.; Gopalan, A.-I.; Lee, K.-P. Nanophase Changes in Nickel Doped Titania Composites by Thermal Treatment and Photocatalytic Destruction of $\mathrm{NO}_{\mathrm{x}}$. J. Nanosci. Nanotechnol. 2015, 15, 7262-7271. [CrossRef]

165. Tobaldi, D.M.; Piccirillo, C.; Rozman, N.; Pullar, R.C.; Seabra, M.P.; Škapin, A.S.; Castro, P.M.L.; Labrincha, J.A. Effects of $\mathrm{Cu}, \mathrm{Zn}$ and $\mathrm{Cu}-\mathrm{Zn}$ addition on the microstructure and antibacterial and photocatalytic functional properties of $\mathrm{Cu}-\mathrm{Zn}$ modified $\mathrm{TiO}_{2}$ nano-heterostructures. J. Photochem. Photobiol. A Chem. 2016, 330, 44-54. [CrossRef]

166. Lorencik, S.; Yu, Q.L.; Brouwers, H.J.H. Photocatalytic coating for indoor air purification: Synergetic effect of photocatalyst dosage and silica modification. Chem. Eng. J. 2016, 306, 942-952. [CrossRef]

167. Tobaldi, D.M.; Pullar, R.C.; Gualtieri, A.F.; Otero-Irurueta, G.; Singh, M.K.; Seabra, M.P.; Labrincha, J.A. Nitrogen-modified nano-titania: True phase composition, microstructure and visible-light induced photocatalytic $\mathrm{NO}_{\mathrm{x}}$ abatement. J. Solid State Chem. 2015, 231, 87-100. [CrossRef]

168. Yamamoto, A.; Mizuno, Y.; Teramura, K.; Hosokawa, S.; Tanaka, T. Noble-Metal-Free $\mathrm{NO}_{\mathrm{x}}$ Storage over Ba-Modified $\mathrm{TiO}_{2}$ Photocatalysts under UV-Light Irradiation at Low Temperatures. ACS Catal. 2015, 5, 2939-2943. [CrossRef]

169. Folli, A.; Bloh, J.Z.; Armstrong, K.; Richards, E.; Murphy, D.M.; Lu, L.; Kiely, C.J.; Morgan, D.J.; Smith, R.I.; McLaughlin, A.C.; et al. Improving the Selectivity of Photocatalytic $\mathrm{NO}_{x}$ Abatement through Improved $\mathrm{O}_{2}$ Reduction Pathways Using $\mathrm{Ti}_{0.909} \mathrm{~W}_{0.091} \mathrm{O}_{2} \mathrm{~N}_{\mathrm{x}}$ Semiconductor Nanoparticles: From Characterization to Photocatalytic Performance. ACS Catal. 2018, 8, 6927-6938. [CrossRef]

170. Chen, Y.; Tong, S.; Wang, J.; Peng, C.; Ge, M.; Xie, X.; Sun, J. Effect of Titanium Dioxide on Secondary Organic Aerosol Formation. Environ. Sci. Technol. 2018, 52, 11612-11620. [CrossRef]

171. Li, Q.; Li, X.; Li, W.; Zhong, L.; Zhang, C.; Fang, Q.; Chen, G. Effect of preferential exposure of anatase $\mathrm{TiO}_{2}$ $\{001\}$ facets on the performance of $\mathrm{Mn}-\mathrm{Ce} / \mathrm{TiO}_{2}$ catalysts for low-temperature selective catalytic reduction of $\mathrm{NO}_{x}$ with $\mathrm{NH}_{3}$. Chem. Eng. J. 2019, 369, 26-34. [CrossRef]

172. Cerro-Prada, E.; García-Salgado, S.; Quijano, M.Á.; Varela, F. Controlled Synthesis and Microstructural Properties of Sol-Gel $\mathrm{TiO}_{2}$ Nanoparticles for Photocatalytic Cement Composites. Nanomaterials 2019, 9, 26. [CrossRef]

173. Luo, Z.; Poyraz, A.S.; Kuo, C.-H.; Miao, R.; Meng, Y.; Chen, S.-Y.; Jiang, T.; Wenos, C.; Suib, S.L. Crystalline Mixed Phase (Anatase/Rutile) Mesoporous Titanium Dioxides for Visible Light Photocatalytic Activity. Chem. Mater. 2015, 27, 6-17. [CrossRef]

174. Shiraishi, F.; Maruoka, D.; Tanoue, Y. A better UV light and $\mathrm{TiO}_{2}-\mathrm{PET}$ sheet arrangement for enhancing photocatalytic decomposition of volatile organic compounds. Sep. Purif. Technol. 2017, 175, 185-193. [CrossRef]

175. Morin, J.; Gandolfo, A.; Temime-Roussel, B.; Strekowski, R.; Brochard, G.; Bergé, V.; Gligorovski, S.; Wortham, H. Application of a mineral binder to reduce VOC emissions from indoor photocatalytic paints. Build. Environ. 2019, 156, 225-232. [CrossRef]

176. Mull, B.; Möhlmann, L.; Wilke, O. Photocatalytic Degradation of Toluene, Butyl Acetate and Limonene under UV and Visible Light with Titanium Dioxide-Graphene Oxide as Photocatalyst. Environments 2017, 4, 9. [CrossRef]

177. Shayegan, Z.; Haghighat, F.; Lee, C.-S. Photocatalytic oxidation of volatile organic compounds for indoor environment applications: Three different scaled setups. Chem. Eng. J. 2019, 357, 533-546. [CrossRef]

178. Tian, M.-J.; Liao, F.; Ke, Q.-F.; Guo, Y.-J.; Guo, Y.-P. Synergetic effect of titanium dioxide ultralong nanofibers and activated carbon fibers on adsorption and photodegradation of toluene. Chem. Eng. J. 2017, 328, 962-976. [CrossRef]

179. Cheng, Z.; Gu, Z.; Chen, J.; Yu, J.; Zhou, L. Synthesis, characterization, and photocatalytic activity of porous La-N-co-doped $\mathrm{TiO}_{2}$ nanotubes for gaseous chlorobenzene oxidation. J. Environ. Sci. 2016, 46, 203-213. [CrossRef]

180. Enea, D.; Bellardita, M.; Scalisi, P.; Alaimo, G.; Palmisano, L. Effects of weathering on the performance of self-cleaning photocatalytic paints. Cem. Concr. Compos. 2019, 96, 77-86. [CrossRef]

181. Blommaerts, N.; Asapu, R.; Claes, N.; Bals, S.; Lenaerts, S.; Verbruggen, S.W. Gas phase photocatalytic spiral reactor for fast and efficient pollutant degradation. Chem. Eng. J. 2017, 316, 850-856. [CrossRef]

182. Zhu, W.; Koziel, J.A.; Maurer, D.L. Mitigation of Livestock Odors Using Black Light and a New Titanium Dioxide-Based Catalyst: Proof-of-Concept. Atmosphere 2017, 8, 103. [CrossRef] 
183. Toro, C.; Jobson, B.T.; Haselbach, L.; Shen, S.; Chung, S.H. Photoactive roadways: Determination of CO, $\mathrm{NO}$ and VOC uptake coefficients and photolabile side product yields on $\mathrm{TiO}_{2}$ treated asphalt and concrete. Atmos. Environ. 2016, 139, 37-45. [CrossRef]

184. Saeli, M.; Tobaldi, D.M.; Rozman, N.; Sever Škapin, A.; Labrincha, J.A.; Pullar, R.C. Photocatalytic nano-composite architectural lime mortar for degradation of urban pollutants under solar and visible (interior) light. Constr. Build. Mater. 2017, 152, 206-213. [CrossRef]

185. Janus, M.; Zatorska, J.; Zając, K.; Kusiak-Nejman, E.; Czyżewski, A.; Morawski, A.W. Study of nitric oxide degradation properties of photoactive concrete containing nitrogen and/or carbon co-modified titanium dioxide-preliminary findings. Micro Nano Lett. 2016, 11, 231-235. [CrossRef]

186. Law, K.-Y. Definitions for Hydrophilicity, Hydrophobicity, and Superhydrophobicity: Getting the Basics Right. J. Phys. Chem. Lett. 2014, 5, 686-688. [CrossRef]

187. Fujishima, A.; Rao, T.N.; Tryk, D.A. Titanium dioxide photocatalysis. J. Photochem. Photobiol. C Photochem. Rev. 2000, 1, 1-21. [CrossRef]

188. Fujishima, A.; Rao, T.N.; Tryk, D.A. $\mathrm{TiO}_{2}$ photocatalysts and diamond electrodes. Electrochim. Acta 2000, 45, 4683-4690. [CrossRef]

189. Drelich, J.; Chibowski, E. Superhydrophilic and Superwetting Surfaces: Definition and Mechanisms of Control. Langmuir 2010, 26, 18621-18623. [CrossRef]

190. Liu, K.; Cao, M.; Fujishima, A.; Jiang, L. Bio-Inspired Titanium Dioxide Materials with Special Wettability and Their Applications. Chem. Rev. 2014, 114, 10044-10094. [CrossRef]

191. Liu, K.; Jiang, L. Bio-Inspired Self-Cleaning Surfaces. Annu. Rev. Mater. Res. 2012, 42, 231-263. [CrossRef]

192. Fürstner, R.; Barthlott, W.; Neinhuis, C.; Walzel, P. Wetting and Self-Cleaning Properties of Artificial Superhydrophobic Surfaces. Langmuir 2005, 21, 956-961. [CrossRef]

193. Liu, K.; Yao, X.; Jiang, L. Recent developments in bio-inspired special wettability. Chem. Soc. Rev. 2010, 39, 3240-3255. [CrossRef] [PubMed]

194. Wang, R.; Hashimoto, K.; Fujishima, A.; Chikuni, M.; Kojima, E.; Kitamura, A.; Shimohigoshi, M.; Watanabe, T. Light-induced amphiphilic surfaces. Nature 1997, 388, 431-432. [CrossRef]

195. Xu, Q.; Zhang, W.; Dong, C.; Sreeprasad, T.S.; Xia, Z. Biomimetic self-cleaning surfaces: Synthesis, mechanism and applications. J. R. Soc. Interface 2016, 13, 20160300. [CrossRef] [PubMed]

196. Michielsen, S.; Zhang, J.; Du, J.; Lee, H.J. Gibbs Free Energy of Liquid Drops on Conical Fibers. Langmuir 2011, 27, 11867-11872. [CrossRef] [PubMed]

197. Shih, C.-J.; Strano, M.S.; Blankschtein, D. Wetting translucency of graphene. Nat. Mater. 2013, 12, 866-869. [CrossRef]

198. Bhushan, B.; Jung, Y.C. Natural and biomimetic artificial surfaces for superhydrophobicity, self-cleaning, low adhesion, and drag reduction. Prog. Mater. Sci. 2011, 56, 1-108. [CrossRef]

199. Campbell, C.T.; Sauer, J. Introduction: Surface Chemistry of Oxides. Chem. Rev. 2013, 113, 3859-3862. [CrossRef]

200. Thompson, T.L.; Yates, J.T. Surface Science Studies of the Photoactivation of $\mathrm{TiO}_{2} \mathrm{New}_{\text {Photochemical }}$ Processes. Chem. Rev. 2006, 106, 4428-4453. [CrossRef]

201. Thomas, A.G.; Syres, K.L. Adsorption of organic molecules on rutile $\mathrm{TiO}_{2}$ and anatase $\mathrm{TiO}_{2}$ single crystal surfaces. Chem. Soc. Rev. 2012, 41, 4207-4217. [CrossRef]

202. Park, H.; Park, Y.; Kim, W.; Choi, W. Surface modification of $\mathrm{TiO}_{2}$ photocatalyst for environmental applications. J. Photochem. Photobiol. C Photochem. Rev. 2013, 15, 1-20. [CrossRef]

203. Lang, X.; Ma, W.; Chen, C.; Ji, H.; Zhao, J. Selective Aerobic Oxidation Mediated by $\mathrm{TiO}_{2}$ Photocatalysis. Acc. Chem. Res. 2014, 47, 355-363. [CrossRef]

204. Blossey, R. Self-cleaning surfaces-Virtual realities. Nat. Mater. 2003, 2, 301-306. [CrossRef] [PubMed]

205. Fujishima, A.; Zhang, X.; Tryk, D.A. $\mathrm{TiO}_{2}$ photocatalysis and related surface phenomena. Surf. Sci. Rep. 2008, 63, 515-582. [CrossRef]

206. Bai, C. Ascent of Nanoscience in China. Science 2005, 309, 61-63. [CrossRef] [PubMed]

207. Ragesh, P.; Anand Ganesh, V.; Nair, S.V.; Nair, A.S. A review on 'self-cleaning and multifunctional materials'. J. Mater. Chem. A 2014, 2, 14773-14797. [CrossRef]

208. Luna, M.; Mosquera, M.J.; Vidal, H.; Gatica, J.M. Au- $\mathrm{TiO}_{2} / \mathrm{SiO}_{2}$ photocatalysts for building materials: Self-cleaning and de-polluting performance. Build. Environ. 2019, 164, 106347. [CrossRef] 
209. Truppi, A.; Luna, M.; Petronella, F.; Falcicchio, A.; Giannini, C.; Comparelli, R.; Mosquera, M.J. Photocatalytic Activity of $\mathrm{TiO}_{2} /$ AuNRs-SiO 2 Nanocomposites Applied to Building Materials. Coatings 2018, 8, 296. [CrossRef]

210. Luna, M.; Delgado, J.J.; Gil, M.L.A.; Mosquera, M.J. $\mathrm{TiO}_{2}-\mathrm{SiO}_{2}$ Coatings with a Low Content of AuNPs for Producing Self-Cleaning Building Materials. Nanomaterials 2018, 8, 177. [CrossRef]

211. Shen, W.; Zhang, C.; Li, Q.; Zhang, W.; Cao, L.; Ye, J. Preparation of titanium dioxide nano particle modified photocatalytic self-cleaning concrete. J. Clean. Prod. 2015, 87, 762-765. [CrossRef]

212. Li, Q.; Liu, Q.; Peng, B.; Chai, L.; Liu, H. Self-cleaning performance of $\mathrm{TiO}_{2}$-coating cement materials prepared based on solidification/stabilization of electrolytic manganese residue. Constr. Build. Mater. 2016, 106, 236-242. [CrossRef]

213. Janus, M.; Zatorska, J.; Czyżewski, A.; Bubacz, K.; Kusiak-Nejman, E.; Morawski, A.W. Self-cleaning properties of cement plates loaded with N,C-modified $\mathrm{TiO}_{2}$ photocatalysts. Appl. Surf. Sci. 2015, 330, 200-206. [CrossRef]

214. Werle, A.P.; de Souza, M.L.; Loh, K.; Ando, R.; John, V.M. The performance of a self-cleaning cool cementitious surface. Energy Build. 2016, 114, 200-205. [CrossRef]

215. Senff, L.; Tobaldi, D.M.; Lemes-Rachadel, P.; Labrincha, J.A.; Hotza, D. The influence of $\mathrm{TiO}_{2}$ and $\mathrm{ZnO}$ powder mixtures on photocatalytic activity and rheological behavior of cement pastes. Constr. Build. Mater. 2014, 65, 191-200. [CrossRef]

216. Ono, S.; Kishikawa, N.; Kawase, S.; Hayashi, T.; Asano, N. Low-Cost Preparation Method for Anti-Dirt Coating on Concrete Block Using Titanium Oxide Photocatalytic Powder. In Proceedings of the 12th Pacific Rim Conference on Ceramic and Glass Technology, Waikoloa, HI, USA, 21-26 May 2017; John Wiley \& Sons, Inc.: Hoboken, NJ, USA, 2018; pp. 267-277. [CrossRef]

217. Yang, Y.; Ji, T.; Su, W.; Yang, B.; Zhang, Y.; Yang, Z. Photocatalytic $\mathrm{NO}_{\mathrm{x}}$ abatement and self-cleaning performance of cementitious composites with $\mathrm{g}-\mathrm{C}_{3} \mathrm{~N}_{4}$ nanosheets under visible light. Constr. Build. Mater. 2019, 225, 120-131. [CrossRef]

218. Amor, F.; Diouri, A.; Ellouzi, I.; Ouanji, F. Development of Zn-Al-Ti mixed oxides-modified cement phases for surface photocatalytic performance. Case Stud. Constr. Mater. 2018, 9, e00209. [CrossRef]

219. Wang, D.; Hou, P.; Zhang, L.; Xie, N.; Yang, P.; Cheng, X. Photocatalytic activities and chemically-bonded mechanism of $\mathrm{SiO}_{2} @ \mathrm{TiO}_{2}$ nanocomposites coated cement-based materials. Mater. Res. Bull. 2018, 102,262-268. [CrossRef]

220. Zhao, A.; Yang, J.; Yang, E.-H. Self-cleaning engineered cementitious composites. Cem. Concr. Compos. 2015, 64, 74-83. [CrossRef]

221. Jimenez-Relinque, E.; Rodriguez-Garcia, J.R.; Castillo, A.; Castellote, M. Characteristics and efficiency of photocatalytic cementitious materials: Type of binder, roughness and microstructure. Cem. Concr. Res. 2015, 71, 124-131. [CrossRef]

222. Diamanti, M.V.; Paolini, R.; Rossini, M.; Aslan, A.B.; Zinzi, M.; Poli, T.; Pedeferri, M.P. Long term self-cleaning and photocatalytic performance of anatase added mortars exposed to the urban environment. Constr. Build. Mater. 2015, 96, 270-278. [CrossRef]

223. García, L.D.; Pastor, J.M.; Peña, J. Self cleaning and depolluting glass reinforced concrete panels: Fabrication, optimization and durability evaluation. Constr. Build. Mater. 2018, 162, 9-19. [CrossRef]

224. Smits, M.; Huygh, D.; Craeye, B.; Lenaerts, S. Effect of process parameters on the photocatalytic soot degradation on self-cleaning cementitious materials. Catal. Today 2014, 230, 250-255. [CrossRef]

225. Guo, M.-Z.; Maury-Ramirez, A.; Poon, C.S. Photocatalytic activities of titanium dioxide incorporated architectural mortars: Effects of weathering and activation light. Build. Environ. 2015, 94, 395-402. [CrossRef]

226. Vulic, T.; Rudic, O.; Vucetic, S.; Lazar, D.; Ranogajec, J. Photocatalytic activity and stability of $\mathrm{TiO}_{2} / \mathrm{ZnAl}$ layered double hydroxide based coatings on mortar substrates. Cem. Concr. Compos. 2015, 58, 50-58. [CrossRef]

227. Pozo-Antonio, J.S.; Dionísio, A. Self-cleaning property of mortars with $\mathrm{TiO}_{2}$ addition using real diesel exhaust soot. J. Clean. Prod. 2017, 161, 850-859. [CrossRef]

228. Guo, M.-Z.; Maury-Ramirez, A.; Poon, C.S. Self-cleaning ability of titanium dioxide clear paint coated architectural mortar and its potential in field application. J. Clean. Prod. 2016, 112, 3583-3588. [CrossRef] 
229. Sikora, P.; Cendrowski, K.; Markowska-Szczupak, A.; Horszczaruk, E.; Mijowska, E. The effects of silica/titania nanocomposite on the mechanical and bactericidal properties of cement mortars. Constr. Build. Mater. 2017, 150, 738-746. [CrossRef]

230. De la Rosa, J.M.; Miller, A.Z.; Pozo-Antonio, J.S.; González-Pérez, J.A.; Jiménez-Morillo, N.T.; Dionisio, A. Assessing the effects of UVA photocatalysis on soot-coated $\mathrm{TiO}_{2}$-containing mortars. Sci. Total Environ. 2017, 605-606, 147-157. [CrossRef]

231. Laplaza, A.; Jimenez-Relinque, E.; Campos, J.; Castellote, M. Photocatalytic behavior of colored mortars containing $\mathrm{TiO}_{2}$ and iron oxide based pigments. Constr. Build. Mater. 2017, 144, 300-310. [CrossRef]

232. Zanfir, A.-V.; Voicu, G.; Bădănoiu, A.-I.; Gogan, D.; Oprea, O.; Vasile, E. Synthesis and characterization of titania-silica fume composites and their influence on the strength of self-cleaning mortar. Compos. Part B Eng. 2018, 140, 157-163. [CrossRef]

233. Jimenez-Relinque, E.; Castellote, M. Quick assessment of the photocatalytic activity of $\mathrm{TiO}_{2}$ construction materials by nitroblue tetrazolium (NBT) ink. Constr. Build. Mater. 2019, 214, 1-8. [CrossRef]

234. Wang, J.; Lu, C.; Xiong, J. Self-cleaning and depollution of fiber reinforced cement materials modified by neutral $\mathrm{TiO}_{2} / \mathrm{SiO}_{2}$ hydrosol photoactive coatings. Appl. Surf. Sci. 2014, 298, 19-25. [CrossRef]

235. Luo, J.; Zhu, G.; Zhang, F.; Li, Q.; Zhao, T.; Zhu, X. Orthogonal experimentation for optimization of $\mathrm{TiO}_{2}$ nanoparticles hydrothermal synthesis and photocatalytic property of a $\mathrm{TiO}_{2} /$ concrete composite. RSC Adv. 2015, 5, 6071-6078. [CrossRef]

236. Delnavaz, M.; Ayati, B.; Ganjidoust, H.; Sanjabi, S. Application of concrete surfaces as novel substrate for immobilization of $\mathrm{TiO}_{2}$ nano powder in photocatalytic treatment of phenolic water. J. Environ. Health Sci. Eng. 2015, 13, 58. [CrossRef] [PubMed]

237. Kim, H.-J.; Yoon, Y.-S.; Yang, K.-H.; Kwon, S.-J. Durability and purification performance of concrete impregnated with silicate and sprayed with photocatalytic $\mathrm{TiO}_{2}$. Constr. Build. Mater. 2019, 199, 106-114. [CrossRef]

238. Koli, V.B.; Mavengere, S.; Kim, J.-S. An efficient one-pot $\mathrm{N}$ doped $\mathrm{TiO}_{2}-\mathrm{SiO}_{2}$ synthesis and its application for photocatalytic concrete. Appl. Surf. Sci. 2019, 491, 60-66. [CrossRef]

239. García Calvo, J.L.; Carballosa, P.; Castillo, A.; Revuelta, D.; Gutiérrez, J.P.; Castellote, M. Expansive concretes with photocatalytic activity for pavements: Enhanced performance and modifications of the expansive hydrates composition. Constr. Build. Mater. 2019, 218, 394-403. [CrossRef]

240. Carmona-Quiroga, P.M.; Martínez-Ramírez, S.; Viles, H.A. Efficiency and durability of a self-cleaning coating on concrete and stones under both natural and artificial ageing trials. Appl. Surf. Sci. 2018, 433, 312-320. [CrossRef]

241. Jalal, M.; Fathi, M.; Farzad, M. Effects of fly ash and $\mathrm{TiO}_{2}$ nanoparticles on rheological, mechanical, microstructural and thermal properties of high strength self compacting concrete. Mech. Mater. 2013, 61, 11-27. [CrossRef]

242. Sun, R.-D.; Nakajima, A.; Watanabe, T.; Hashimoto, K. Decomposition of gas-phase octamethyltrisiloxane on $\mathrm{TiO}_{2}$ thin film photocatalysts-Catalytic activity, deactivation, and regeneration. J. Photochem. Photobiol. A Chem. 2003, 154, 203-209. [CrossRef]

243. Méndez-Román, R.; Cardona-Martínez, N. Relationship between the formation of surface species and catalyst deactivation during the gas-phase photocatalytic oxidation of toluene. Catal. Today 1998, 40, 353-365. [CrossRef]

244. Cao, L.; Gao, Z.; Suib, S.L.; Obee, T.N.; Hay, S.O.; Freihaut, J.D. Photocatalytic Oxidation of Toluene on Nanoscale $\mathrm{TiO}_{2}$ Catalysts: Studies of Deactivation and Regeneration. J. Catal. 2000, 196, 253-261. [CrossRef]

245. Piera, E.; Ayllón, J.A.; Doménech, X.; Peral, J. $\mathrm{TiO}_{2}$ deactivation during gas-phase photocatalytic oxidation of ethanol. Catal. Today 2002, 76, 259-270. [CrossRef]

246. Marzo, T.; Pratesi, A.; Cirri, D.; Pillozzi, S.; Petroni, G.; Guerri, A.; Arcangeli, A.; Messori, L.; Gabbiani, C. Chlorido and bromido oxaliplatin analogues as potential agents for CRC treatment: Solution behavior, protein binding and cytotoxicity evaluation. Inorg. Chim. Acta 2018, 470, 318-324. [CrossRef]

247. Peral, J.; Ollis, D.F. $\mathrm{TiO}_{2}$ photocatalyst deactivation by gas-phase oxidation of heteroatom organics. J. Mol. Catal. A Chem. 1997, 115, 347-354. [CrossRef]

248. Van Driel, B.A.; Wezendonk, T.A.; van den Berg, K.J.; Kooyman, P.J.; Gascon, J.; Dik, J. Determination of early warning signs for photocatalytic degradation of titanium white oil paints by means of surface analysis. Spectrochim. Acta Part A Mol. Biomol. Spectrosc. 2017, 172, 100-108. [CrossRef] 
249. Yousif, E.; Haddad, R. Photodegradation and photostabilization of polymers, especially polystyrene: Review. SpringerPlus 2013, 2, 398. [CrossRef] [PubMed]

250. Samain, L.; Silversmit, G.; Sanyova, J.; Vekemans, B.; Salomon, H.; Gilbert, B.; Grandjean, F.; Long, G.J.; Hermann, R.P.; Vincze, L.; et al. Fading of modern Prussian blue pigments in linseed oil medium. J. Anal. At. Spectrom. 2011, 26, 930-941. [CrossRef]

251. Pacheco-Torgal, F.; Jalali, S. Nanotechnology: Advantages and drawbacks in the field of construction and building materials. Constr. Build. Mater. 2011, 25, 582-590. [CrossRef]

252. Shandilya, N.; Le Bihan, O.; Bressot, C.; Morgeneyer, M. Emission of Titanium Dioxide Nanoparticles from Building Materials to the Environment by Wear and Weather. Environ. Sci. Technol. 2015, 49, 2163-2170. [CrossRef]

253. Vorbau, M.; Hillemann, L.; Stintz, M. Method for the characterization of the abrasion induced nanoparticle release into air from surface coatings. J. Aerosol Sci. 2009, 40, 209-217. [CrossRef]

254. Le Bihan, O.; Shandilya, N.; Gheerardyn, L.; Guillon, O.; Dore, E.; Morgeneyer, M. Investigation of the release of particles from a nanocoated product. Adv. Nanopart. 2013, 2, 39-44. [CrossRef]

255. Kebede, M.A.; Varner, M.E.; Scharko, N.K.; Gerber, R.B.; Raff, J.D. Photooxidation of $\mathrm{Ammonia}$ on $\mathrm{TiO}_{2}$ as a Source of $\mathrm{NO}$ and $\mathrm{NO}_{2}$ under Atmospheric Conditions. J. Am. Chem. Soc. 2013, 135, 8606-8615. [CrossRef] [PubMed]

256. Han, B.; Li, Z.; Zhang, L.; Zeng, S.; Yu, X.; Han, B.; Ou, J. Reactive powder concrete reinforced with nano $\mathrm{SiO}_{2}$-coated $\mathrm{TiO}_{2}$. Constr. Build. Mater. 2017, 148, 104-112. [CrossRef]

257. Marugán, J.; López-Muñoz, M.-J.; van Grieken, R.; Aguado, J. Photocatalytic Decolorization and Mineralization of Dyes with Nanocrystalline $\mathrm{TiO}_{2} / \mathrm{SiO}_{2}$ Materials. Ind. Eng. Chem. Res. 2007, 46, 7605-7610. [CrossRef]

258. Pierpaoli, M.; Zheng, X.; Bondarenko, V.; Fava, G.; Ruello, M.L. Paving the Way for A Sustainable and Efficient $\mathrm{SiO}_{2} / \mathrm{TiO}_{2}$ Photocatalytic Composite. Environments 2019, 6, 87. [CrossRef]

(C) 2020 by the authors. Licensee MDPI, Basel, Switzerland. This article is an open access article distributed under the terms and conditions of the Creative Commons Attribution (CC BY) license (http://creativecommons.org/licenses/by/4.0/). 